TE WHARE WĀNANGA O TE ÜPOKO O TE IKA A MĀUI

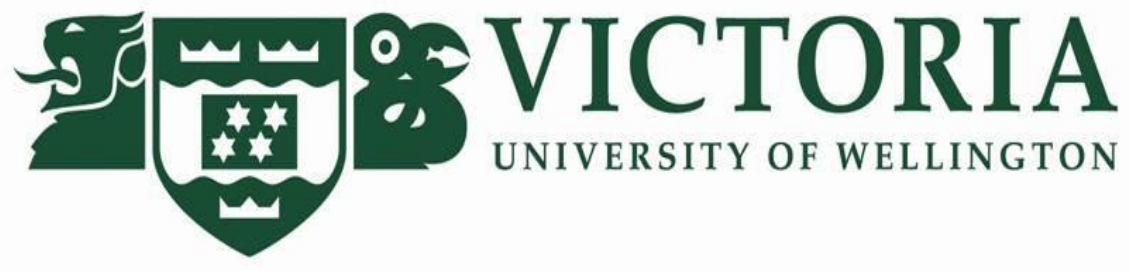

\title{
Water as a tool for development. An analysis of the conflict of the Ñuble River, Chile
}

By

Cristian Leaman-Constanzo

A thesis submitted to Victoria University of Wellington in partial fulfilment of requirements for the degree of Master of Development Studies 2013.

School of Geography, Environment and Earth Sciences

Victoria University of Wellington 


\section{Abstract}

After three decades of neoliberal policies, there are growing concerns in Chile about how nature is used and understood. These concerns are reflected in the relationship between humans and natural water bodies which has reconceptualised the use of and access to water, especially for rural communities. These reconceptualisations have been affected by the model of water rights and river basin governance adopted which have raised issues about social inequality. As a result, rural communities have argued for greater participation in decision-making on matters that affect their lives.

This thesis explores conflict that arose around the Punilla Dam Project on the Nuble River, Biobío Region in Chile. The research employs a political ecology perspective to explore the socio-environmental outcomes of water management in this case and in Chile more generally. The case illustrates how water is important for Chile as a tool for development, the role environmental institutions play, and the tensions between peasant communities, irrigators and hydroelectric interests, while placing these tensions in the context of wider economic and political structures. It is clear that water is key in Chile, hence an examination of the encounter between the model of development and nature is required. I argue that the outcomes of these encounters will increase social inequality and marginalisation, showing that a water project is not always good for all. The omission of these issues in places often rich both in biodiversity and socio-cultural heritage is a cause of concern for Chile and more globally.

Keywords: Development, water management, political ecology, participation, neoliberalism 


\section{Acknowledgements}

This journey could have not been done without a bunch of people who supported and encouraged me along the way.

Firstly, I am very grateful of having worked with Dr Sophie Bond as supervisor. Her clarity, insightful ideas, and "harsh" editing, made this thesis an enjoyable and great learning process. Her guidance, support and inspiration were crucial for me. Many thanks Sophie.

Secondly, I have to say thanks to the students and staff of the School of Geography, Environment, and Earth Sciences and the Faculty of Science. Some of you were an inspiration for me just with simple details of listening and discussing some issues of my entire research. Those chat around coffees or beers were another alternative way to find inspiration as well. Thank guys.

Thirdly, thanks to the all participants of this research who shaved their time, stories, tea, mate, tortilla, and respect. Without them most of my results would not have been possible. Also, I am grateful of my scholarship Becas ChileConicyt awarded me with this amazing opportunity to increase my knowledge.

Special dedication to my parents Erika and Felix for their efforts in my raising and educating. Their examples of life, values, background, and love have shape myself as a men pursuing my dreams. I really love you both. To my tías en Chillan, my brothers, my whole family and friends in Chile. Their support and love is unconditional, and all of you are my inspiration. Los quiero mucho.

Finally to Marcela, my source of love, harmony, and motivation. Thanks for being patient, supportive, fair and committed. Without you much of this would have been not possible, but your firm compromise to believe in our dreams makes that this and other achievements an invaluable treasure that we have built together. More dreams and achievements will come, and I hope you always will be there. Te amo mucho. 


\section{Table of Contents}

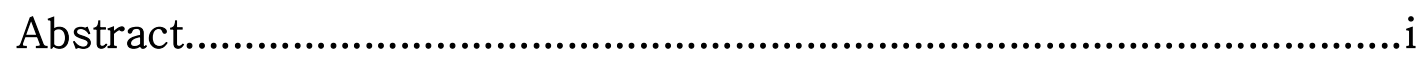

Acknowledgements.......................................................................ii

Table of

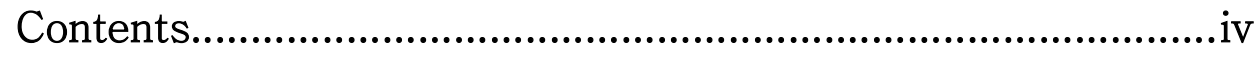

List of Figure........................................................................................ vii

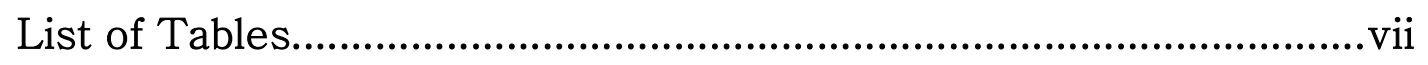

List of

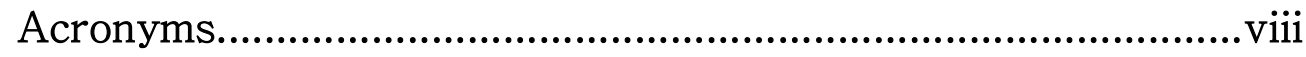

Chapter 1. Introducing the research................................................

1.1 The genesis of a story .................................................. 1

1.1.1 First warning: Water as a private good rather than communitarian ................................................................. 1

1.1.2 Second warning: Prosperity, abandonment and a river .......2

1.1.3 Framing the research problem in a general sense .............. 3

1.2 Neoliberalism and water management ................................. 3

1.3 Managing water in Chile......................................................... 4

1.4 The biophysical and social context of Nuble River: An

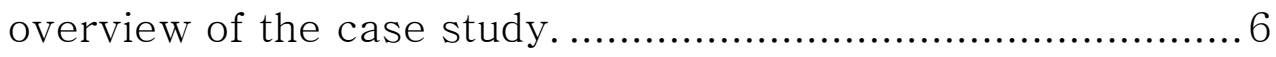

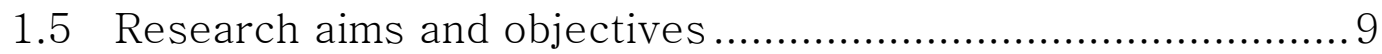

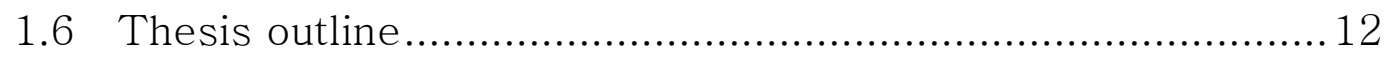

Chapter 2. Research design: Introducing the methodology...................15

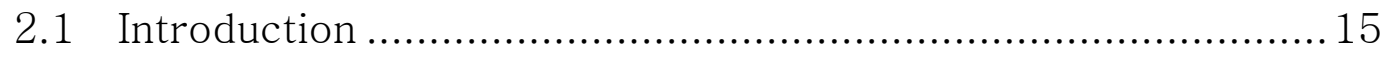

2.2 Philosophical approach to the research .............................. 15

2.2.1 Social constructivism, discourse and power ..................... 16

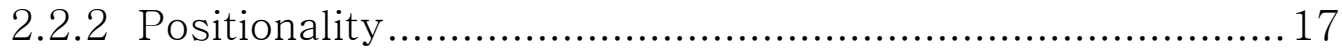

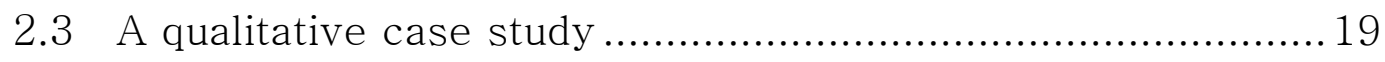

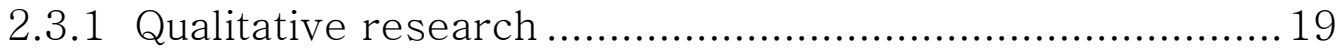

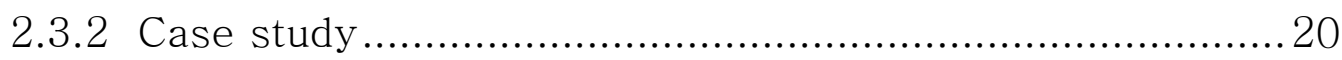

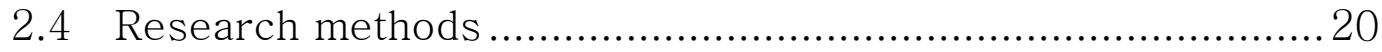

2.4.1 Semi-structured interviews and choice of participants .... 21

2.4.2 Participant observation ................................................. 23 


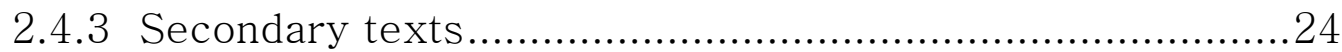

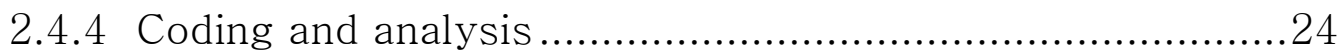

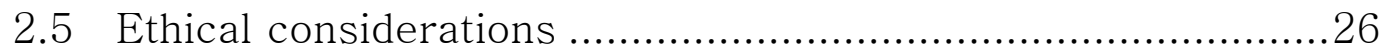

2.5.1 Ethical issues and relationships with contributors ............26

2.5.2 Victoria University of Wellington code of ethics ...............27

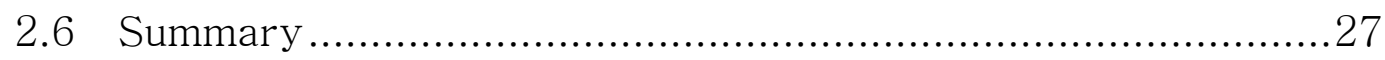

Chapter 3. Approaching water considering the literature....................29

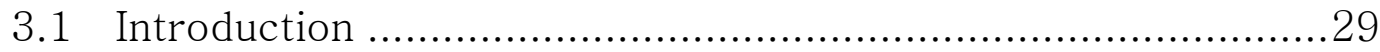

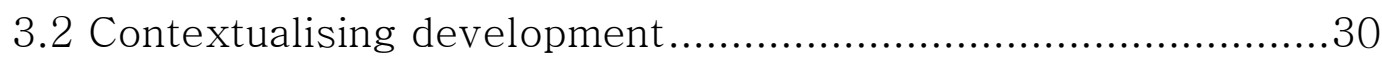

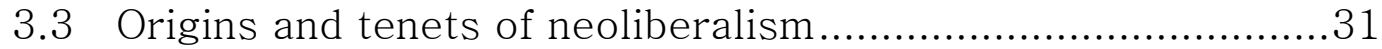

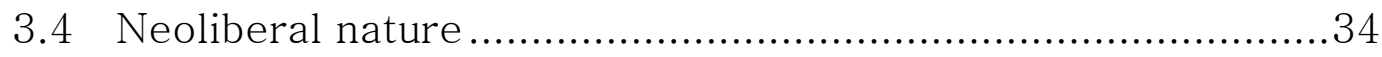

3.5 The neoliberal Chilean water market ..................................36

3.6 The problematic efficiency of the Water Code: Access for all?

3.7 Linking the hydrosocial cycle, techno-natures and

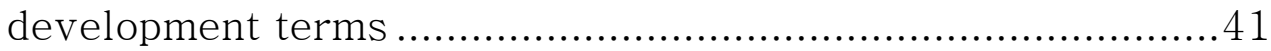

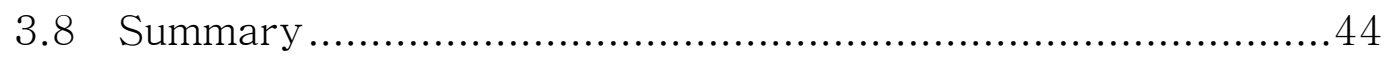

Chapter 4. The neoliberal institutions in the Chilean context: Past and

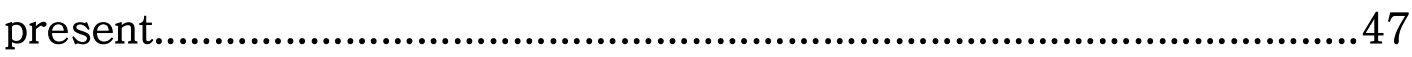

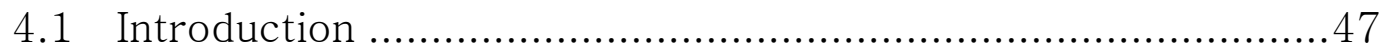

4.2 Neoliberal reforms in Chile .............................................4 47

4.3 The tools of free-market managing nature: The Chilean Water

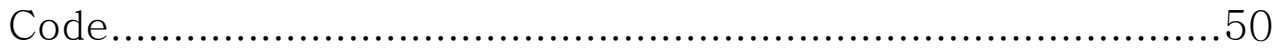

4.4 Chilean Water Code: Neoliberalising nature ...........................53

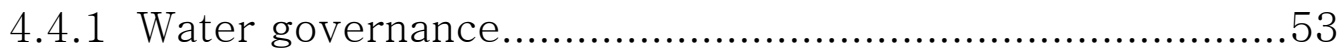

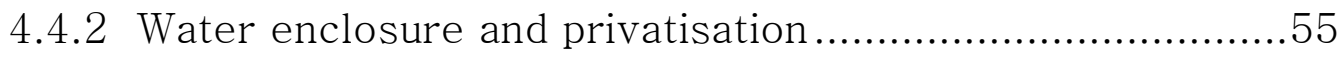

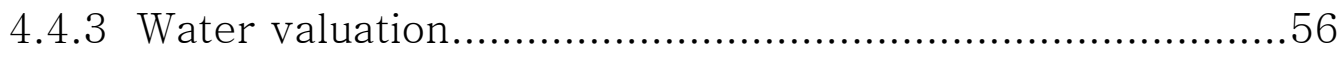

4.5 The role of environmental institutions .................................57

4.5.1 Chile's environmental institutions: A history of (in) convenience ..........................................................57

4.5.2 Assessing nature: Conceived, reformed, commodified ......59

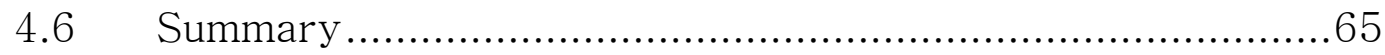

Chapter 5. Negotiating water: Nuble River stakeholders, conflicts and

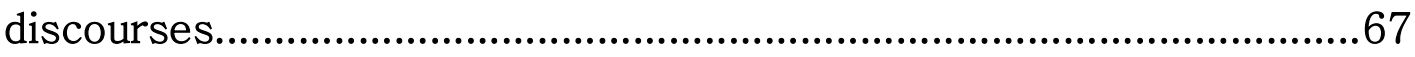

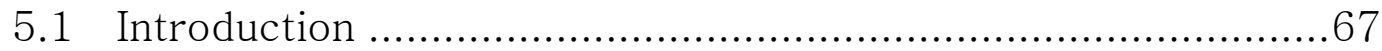

5.2 Farmers and irrigation: Markets, rights and lobby .................67 
5.3 Energy crisis, power companies and their effective "power" 74

5.4 Conservation and development: San Fabián de Alico communities and sustainable development.......................81

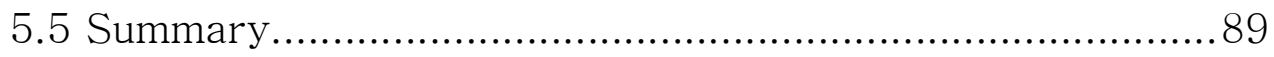

Chapter 6. The contested use of water as a tool for development.......93

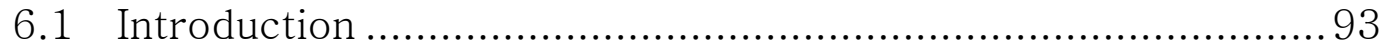

6.2 Explaining the progress of Chile: Water used as a tool for

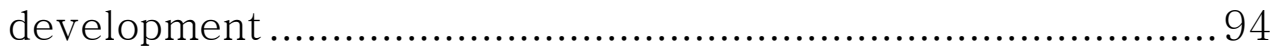

6.3 Water markets and rights based model is neither successful

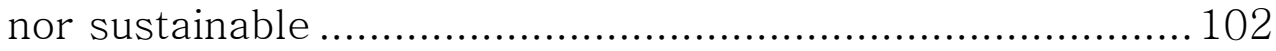

6.4 Current water management in Chile as it stands is not good for

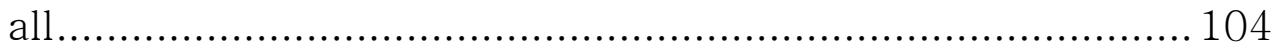

6.5 The encounter between neoliberalism and nature in Chile has increased social inequalities and marginalisation ................ 107

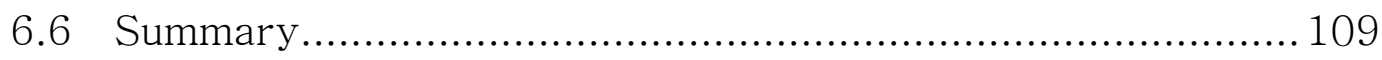

Chapter 7. Reflections, findings, and suggestions on water management in Chile 113

7.1 Interpreting findings: Conclusions and implications from a case

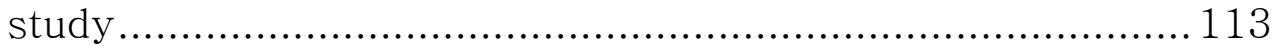

7.2 Limitations in the process ................................................ 116

7.3 Further research possibilities ......................................... 117

7.4 Recommendations and suggestions .................................. 118

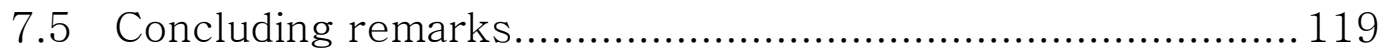

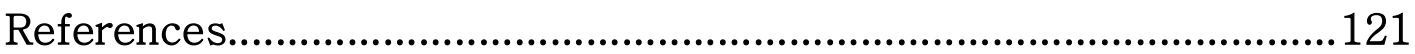

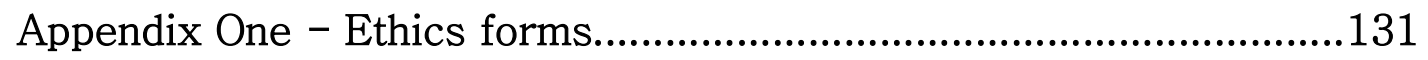

Interview schedule for participants in English: ....................... 137

Interview schedule for participants in Spanish: ....................... 138 


\section{List of Figures}

Figure 1.1 Chile and its geographical location............................................6

Figure 1.2 The area of influence of Nuble River and its tributaries....................7

Figure 1.3 Main stakeholders involved in the conflict of Nuble River.................9

Figure 4.4 Organisational chart Ministry of Environment..................................62

Figure 5.5 Sign in the main highway of the country for the dam project on the Nuble River................................................................................... 73

Figure 5.6 Local signs against the dam.............................................. 82

Figure 5.7 The huemul and its place in the Chilean national coat of arms.........83

\section{List of Tables}

Table 2.1 List of interview participants................................................22 


\section{List of Acronyms}

\begin{tabular}{|c|c|c|}
\hline Acronyms & Spanish & English \\
\hline \multirow[t]{2}{*}{ CODEFF } & Comité Nacional Pro Defensa de la & National Committee for the \\
\hline & Fauna y Flora & Protection of Flora and Fauna \\
\hline \multirow[t]{2}{*}{ CONAMA } & Comisión Nacional del Medio & National Environmental \\
\hline & Ambiente & Commission \\
\hline CNR & Comisión Nacional de Riego & National Irrigation Commission \\
\hline \multirow[t]{2}{*}{ COREMA } & Comisión Regional del Medio & Regional Environmental \\
\hline & Ambiente & Commissions \\
\hline DGA & Dirección General de Riego & General Directory of Water \\
\hline \multirow[t]{2}{*}{ SEA } & Sistema de Evaluación Ambiental & Environmental Assessment \\
\hline & & Service \\
\hline GORE & Gobierno Regional & Regional Government \\
\hline \multirow[t]{2}{*}{ INDAP } & Instituto de Desarrollo & Institute of Agricultural \\
\hline & Agropecuario & Development \\
\hline $\mathrm{MOP}$ & Ministerio de Obras Publicas & Ministry of Public Works \\
\hline \multirow[t]{2}{*}{ SEIA } & Sistema de Evaluación de Impacto & System of Environmental Impact \\
\hline & Ambiental & Assessment \\
\hline
\end{tabular}





\section{Chapter 1}

\section{Introducing the research}

\subsection{The genesis of a story}

To introduce the focus of the research in this thesis, I will begin by telling two stories derived from previous experience working with water in Chile. These stories carry explicit warnings about water management, development and local people.

\subsubsection{First warning: Water as a private good rather than communitarian}

As an agricultural engineering student in Chile, I designed a potable water system in a deprived and isolated community on the coast of the Biobío Region in Chile. Over two months in 2002 I lived with locals and worked towards solving their long-term water issues. For many years, fathers, mothers, children, and grandparents had been walking kilometres up the hill to collect water for their daily needs. They knew where a small stream accumulated a sufficient amount of water to supply their community, comprised at that time of 40 families. When we finished the project and the new water system was finally running, the families, local government staff involved in the project and myself gathered around an 'asado' (a traditional barbeque and social event) to celebrate this enormous change for the locality. The implementation of the new water supply went beyond the design of the system (although very basic), and involved participatory planning and consultation, as well as the constitution of a local committee to administer and maintain the system.

However, a few years later, it became evident that the project had stalled. Ownership of water in the stream had been transferred to a third party as water 
rights were formally allocated. The third party was unwilling to fund a continuation of the project.

\subsubsection{Second warning: Prosperity, abandonment and a river}

In 2004, I was working at a non-governmental organization (NGO) that operates across Chile promoting ways to overcome poverty in rural areas through strengthening social capital, economic development, participation in decisionmaking and rescuing local values and culture. Once again, it was in the Biobío region of Chile but this time in the Andes Mountains (Antuco village). There, during the 1960s the first of a series of large hydropower dams was constructed using a lake located in the mountains. The construction of these dams created many jobs and brought new income for local communities and workers that migrated to the area, generating prosperity. However, when the construction finished, most of the workers left the area, schools were closed, new settlements were abandoned, and the dams generated only a few permanent new jobs for locals. By 2004, the district had become one of the poorest of the region. Locals continue to have difficulties accessing the river because the dam owners have exclusive water rights over the river basin, so people cannot use it even for recreational purposes. Most of the river along the valley is bordered with fences that prohibit access.

Now Endesa Chile, the largest private electric utility company in the country and the company that owns the hydropower stations, delivers a sum of money to the local government which is used for a yearly Music Festival. The company neglects further funding for local activities. In addition, most taxes payable by the company are paid in Santiago (the Chilean capital city), not in Antuco village. In my role for the NGO, I tried to encourage them to support local initiatives to overcome poverty. This included considering local tourism ventures that might have river access and addressing the changing water levels. The answer they gave was "no" and their connection with locals remains solely through the Music Festival. This story warns that the projected economic benefit of large infrastructure construction is often short-lived. Moreover, such a warning should perhaps be 
considered in respect of the case study in the present research detailed in the following sections.

\subsubsection{Framing the research problem in a general sense}

What do the stories above tell us? Water is an essential element in our daily life, not just for drinking but also for recreation, irrigation, showering, washing and so on. In many cities and even rural areas, to have access to this element is simple and automatic. However, these stories specifically demonstrate how the ways in which we access and consume water have been reshaped under policies that have involved privatisation processes, imposed fares and costs for consumers, and granted rights to a few as owners of the water. This situation creates a huge challenge in the present, but more so to our future generations.

This thesis explores some questions related to the management of water in Chile and how this has affected development for rural communities, planning and environmental management, and the roles of institutions working with or related to water. In order to achieve this, I focus on the case of the Nuble River in the Biobío Region, particularly the conflict that arose from the proposed dam on the river.

This complex scenario occurs in a country that has radically embraced neoliberalism. Chile adopted a neoliberal model more than 30 years ago under the Pinochet dictatorship, and despite some minor adjustments the model has been deepened and strengthened by the democratic governments since 1990 (Budds, 2004; Carruthers, 2001). Nowadays, Chile is facing many social and environmental issues as a result of this ideological, political and environmental project (Bauer, 2004; Galaz, 2004).

\subsection{Neoliberalism and water management}

For many years, natural resources were used without taking into consideration their limits and constraints. In response, neoliberal thinkers focused their efforts towards more efficient use of goods of nature through market 
regulation (Bakker, 2010). Neoliberal approaches have permeated water management in both global north and south. In these contexts, management has focused on achieving efficiency (Bakker, 2010; Larner, 2000; Liverman \& Vilas, 2006), resulting in water supply, access or use rights transferring to the private sector. This has reconceptualised the relationship between humans and natural water bodies, and has led to debates among scholars and international institutions about an equitable and fair access to water (Budds, 2009).

Therefore, a thorough understanding of the conceptual frameworks of neoliberalism creates new spaces for political ecologies and socio-natural relationships that need to be understood (Bakker, 2007). In the case of Chile and after three decades of neoliberal policies, there are growing concerns about the implications of understanding and using nature under a neoliberal framework. Within this discussion, environmental and development studies play a vital role. They have the tools and knowledge to explore ways in which communities are included or not in the process of decision-making, and the social and environmental consequences this has.

\subsection{Managing water in Chile}

Scholars have considered the relationship between neoliberal ideas and nature and how these encounters have led to numerous drawbacks depending on the context where they occur (Bakker, 2010; Castree, 2008b; Larner, 2000). In the particular case of Chile, this encounter has been considered 'a successful model' (Carruthers, 2001, p. 343). Neoliberalism in Chile has led to steady economic growth and increased participation in global markets. However, it has also led to an increase in terms of inequality, environmental degradation and social conflicts (Altieri \& Rojas, 1999; Carruthers, 2001).

Of the Latin American countries, Chile made some of the deepest neoliberal reforms with regards to the environment and resources (Liverman \& Vilas, 2006). Water management in Chile is regulated under the Water Code which was 
introduced in 1981. It aimed to improve water use because for many years water was viewed as inexhaustible, and therefore became an overused resource. However, the Code and other strategies of governance were influenced by neoliberal approaches, which sought to boost the sustainable use of water resources (Galaz, 2004). But over time water became converted into an economic good, said to be more efficiently managed through the market (Bakker, 2005).

The Chilean Water Code creates the ability to trade water on the market. Water became a valued and limited resource, with price, responsibilities, owners and rights, which allegedly increases the efficiency of its use. Nevertheless, scholars question the real goals behind the Water Code (Budds, 2004, 2009), because rich and wealthy families, together with big companies, were able to buy more water rights than the rest of the population, creating inequalities in the access to water. As a result, rural communities did not develop further and poverty increased dramatically (Liverman \& Vilas, 2006). This inequality has been made clear in recent times due to the degree of water rights that are in the hands of mining and energy industries, most of them foreign owned companies.

Here, the technocratic approach mentioned in the neoliberal natures literature, has deeply influenced legislation, policies and norms related to the environment (Budds, 2009; Liverman \& Vilas, 2006). The Pinochet legacy of a minimised role of the state and an overemphasised market, together with a market environmentalism and green capitalism approach have dramatically shaped Chilean environmental and development policies. These issues are clearly demonstrated in the Nuble River conflict, the case study for this research, which will explore the complexities and implications of water use in Chile under the neoliberal model of management provided by the Water Code. The explicit research focus is discussed in section 1.5 below, after introducing the case study in more detail in the following section. 


\subsection{The biophysical and social context of Nuble River:}

\section{An overview of the case study.}

The Nuble River is located in the Biobío region, four hours northeast of Chile's second largest city Concepcion, near the small town of San Fabián de Alico. This river basin crosses part of the region and discharges into the Itata River before reach the sea.

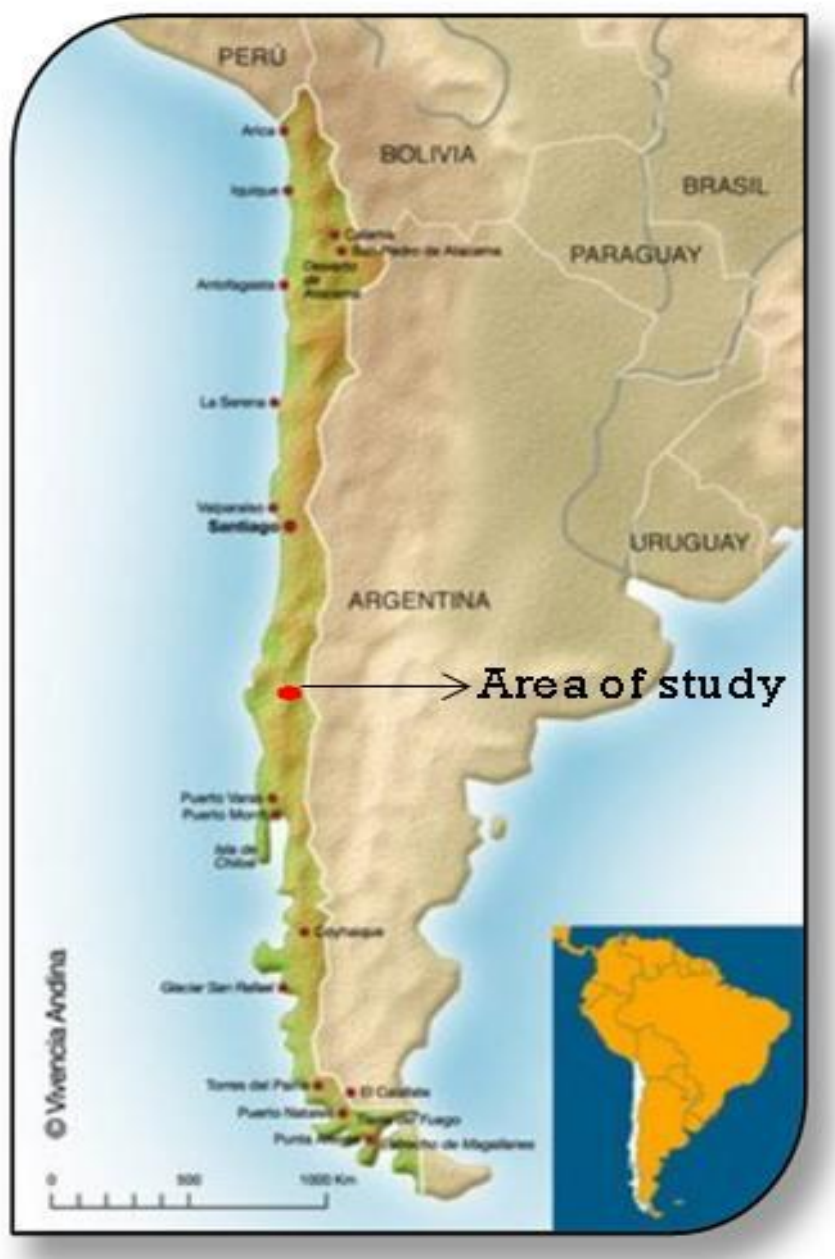

Figure 1.1 Chile and its geographical location Source: Adapted from http://www.vivenciaandina.com by C. Leaman-Constanzo

The projected dam on the Nuble River is a scheme designed to be built 30 $\mathrm{km}$ east of the town of San Fabián de Alico, and it has an estimated cost of US\$145 
million (Seia, 2011). The main objectives of the dam are firstly, to regulate water resources on the Nuble River in order to provide water security for irrigation, and extending the area irrigated from 44,000 to 66,000 hectares within the districts of Chillán, San Carlos, and San Fabián de Alico among others (see figure 1.2). Secondly, the dam will generate hydroelectric power at an annual average of 525 GWh with a nominal power of 94 MW (Seia, 2011).

The water storage projected is 600 million cubic metres, where the floodplain reaches an area of approximately 1,700 hectares. The dam wall will have a height of 136.5 meters, and will be placed directly on the rock of the river (Seia, 2011). However, some of the main negative impacts identified relate to the relocation of around 40 families present there. Also, another significant effect is the loss of 690 hectares of native forest, loss of 11 archaeological sites, and loss of aquatic flora and fauna downstream of the dam (Seia, 2011).

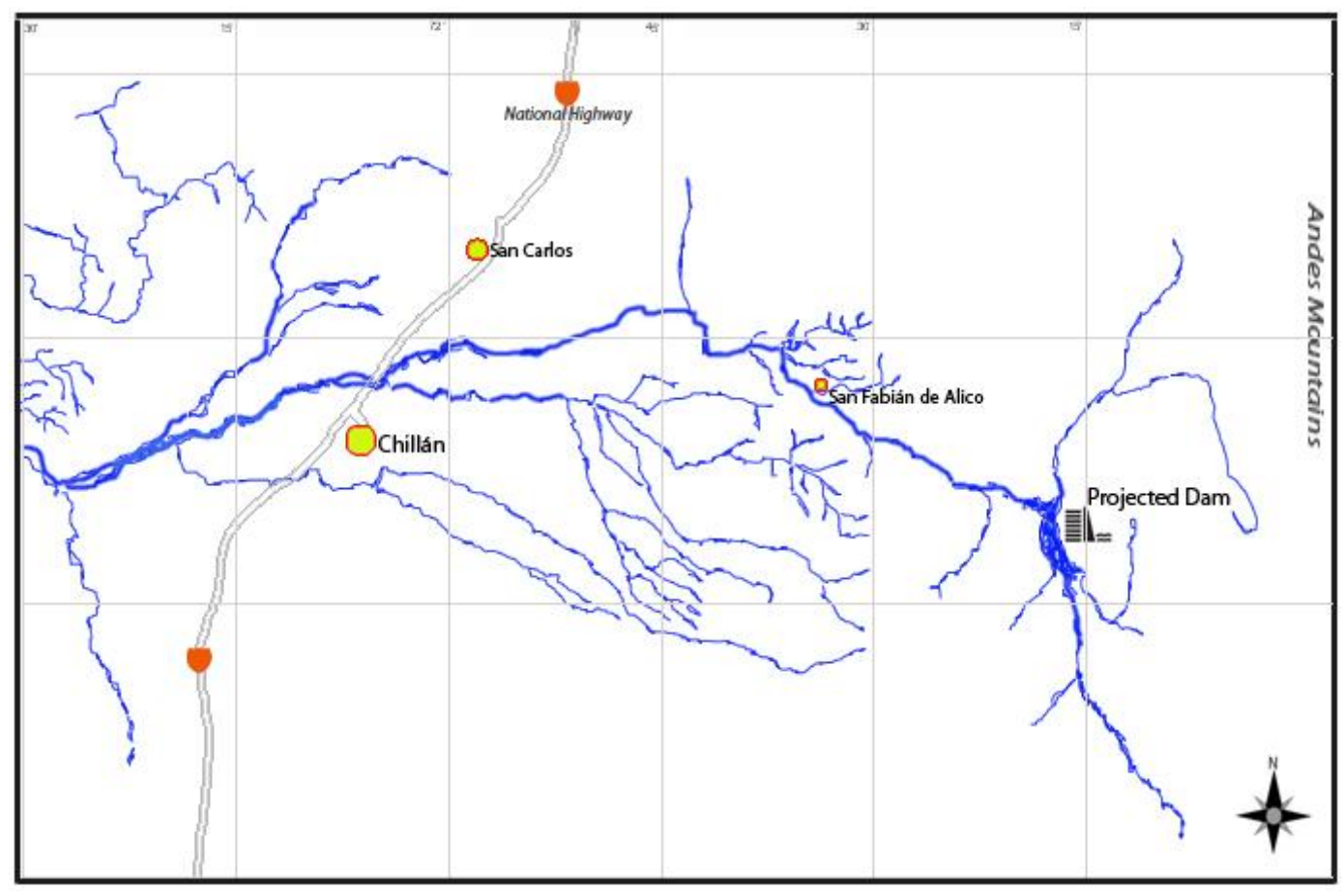

Figure 1.2 The area of influence of Nuble River and its tributaries Source: Adapted from SEA (2011) by Katia Guillof 
The origins of this project began in 1956 as a solution for irrigators downstream who were suffering water scarcity in their agricultural production. These farmers created an association to defend and realise this project which would favour more than 25,000 people associated with agriculture (Punilla, n. d.). However, this project did not materialize due to a lack of support from the governments of that time.

More recently, in the mid-1990s Chile faced an energy crisis that redefined the energy agenda in the country (Bastias, 2010). Politicians and technical staff proposed that the dam could address both water and energy issues by generating electricity while supplying water for irrigation. Fitting with increasing recognition at a national level, of the importance of water for economic development, the project has been firmly back on the agenda.

For over 80 years irrigators have been waiting for this work which intends to boost the agricultural production of this area, and consequently supply the food chain at national and international markets. However, the cost of this project and the current energy shortage affecting Chile has led to the central Government to consider this dam as a multi-use one. Hence, this dam will provide power through hydroelectric generation for both the region and the country, and water for irrigators-most of them wealthy farmers- downstream (Punilla, n. d.).

Yet local communities, together with the local government and some politicians, strongly disagree with this project which will force around 40 families to relocate and flood an area of 1,700 hectares. Moreover, the dam is projected over an area declared recently as a World Biosphere Reserve by UNESCO due to its unique environment (UNESCO, 2011) where one of the last populations of Huemul, an animal that is a national symbol in Chile, still lives. Moreover, the area has a high level of poverty and most for the economic activities of these people is linked with tourism and other agricultural activities that river provides (Pladeco, 2008). 
Therefore, four main stakeholders can be identified in this conflict, as is shown in figure 1.3 which helps to establish how these participants are involved in the case study.

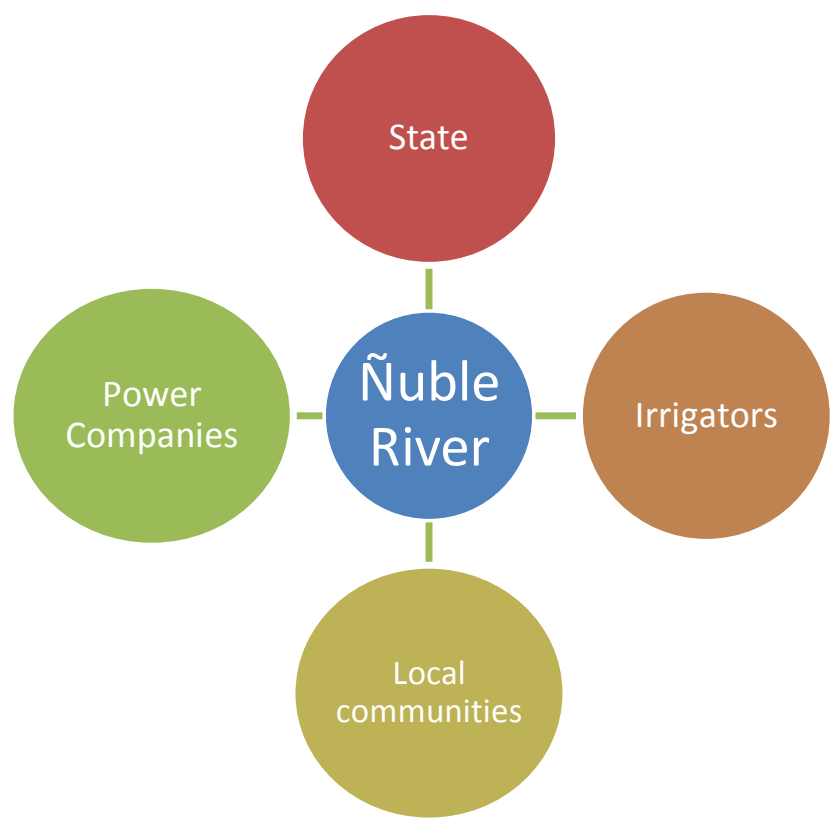

Figure 1.3 Main stakeholders involved in the conflict of Nuble River Source: C. Leaman-Constanzo

\subsection{Research aims and objectives}

\section{What?}

This thesis aims to explore the complexities of the use of water in Chile in a rural context, taking a broad political ecology theoretical approach. In particular, the research will investigate the conflict over the Nuble River to understand the discourses in the use of water and how these discourses are conceived, implemented and negotiated between different stakeholders in a neoliberal context.

\section{Why?}

By engaging in this conflict the research provides an understanding of the priorities that dictate how natural resources are used in Chile, especially water. It incorporates local and regional perspectives through details of the case study, while placing these in the context of wider economic and political structures. 
Exploring the discourses around water use will facilitate understanding the contested scenarios that arise when neoliberalism meets nature. This is critical because of the way in which neoliberalism tends to commodify the biophysical world whereby nature must be used efficiently with price regimes and rights. This commodification of nature has led in some places to social marginalization as a product of a market model. Water management in Chile, in particular the Nuble River, can be considered an example of the commodification of nature where conflict results, and will therefore provide the means to explore these issues.

Through the perspectives of diverse stakeholders involved in the Nuble River conflict, this research seeks to address the incorporation of these different voices towards water management at regional and national levels where decisionmaking occurs.

\section{How?}

Due to the location of the project, this is not considered large at the national level, but it is part of intense debate at the local and regional scale, making this conflict suitable for investigation through the lens of political ecology. Here, I seek 'to understand the complex relations between nature and society through a careful analysis of what one might call the forms of access and control over resources and their implications for environmental health and sustainable livelihoods' (Watts, 2000, p. 257). Political ecology is a diverse field that critically inquires into political and economic changes and tension in a particular context, but it is useful in terms of challenging notions of development, participation, democracy, sustainability among others (Watts \& Peet, 2004).

The value of using political ecology as a lens for my research is that this approach first, is concern with power, knowledge, and the discourses of individuals and groups (Watts \& Peet, 2004). In this regard, many current scholars (Dean, 2010; Li, 2007b; Robbins, 2012; Watts, 2003) have focussed their studies in political ecology around Foucault's concept of power/knowledge, especially how this concept is related with the notion of governmentality (Foucault, 1991). Foucault developed the concept of governmentality as a critique of the traditional 
understanding of power as exclusively exercised by the State's agencies, rather Foucault argued that power is embedded in the relational actions of the population, and the knowledge that it creates (Li, 2007a). Moreover, political ecology addresses the relationship between nature and society, and how social and material elements have changed this relationship over the time (Robbins, 2012) Finally, this approach engages in the contested terrain of neoliberal ideas managing nature 'drawing attention to historical shifts from roll-back to roll-out neoliberalism' (Bondi \& Laurie, 2005, p. 3).

All of these features of political ecology help to shape the whole process of this research, and contribute to a critical understanding of the ways in which nature has been neoliberalised in different ways in the Biobío Region in Chile, particularly on the Nuble River where very little academic research has been undertaken on this matter.

Hence, the primary research question of this thesis is:

\section{How is water understood and managed as a tool for development in Chile by different actors?}

Underlying this question are the following specific questions about the case study area.

1. How is neoliberalism articulated in the discourses employed by the stakeholders in the Nuble River conflict? How is the conflict negotiated?

2. What are the social and environmental implications of the relationship between neoliberalism and nature in the case study?

In order to achieve the above mentioned aims, this research addresses these questions by exploring the interaction of state, private, civil society and local 
communities around rural development and water management. Hence, using qualitative methods to analyse the data, the research intends to contribute to reflections on water management policy in Chile at the national level using a discourse analysis to reveal how the stakeholders involved have articulated their power relations around the river.

\subsection{Thesis outline}

Chapter two introduces the research design for the thesis. It situates the research within an appropriate epistemology with a social constructivist framework that facilitates a discourse analysis of the data collected. Here, the philosophical approach and methodology chosen for the thesis is explained. Chapter Two also provides a discussion on ethical considerations, challenges and limitations of the fieldwork.

Chapter three provides an overview of the relevant literature. It begins by examining the origins of neoliberalism, focusing in particular in the neoliberal nature debate. It then introduces how the encounter between neoliberalism and nature has been addressed by scholars, and how this encounter has shaped Chilean society through the operation of the Water Code, the main tool of water management in the country. It concludes by linking the hydro-social cycle and development to highlight that control and access to water are associated with land, technology, ownership, and power relations in some societies.

Chapter four contributes details of how the neoliberal project took place in Chile, the circumstances that led to the adoption of neoliberal measures, and how these measures influenced the new role of the State. It then explains in detail the Water Code, as well as the role of environmental institutions in assessing projects that use nature. Part of this analysis reflects the opinions of some of the participants of this research.

Chapter five presents the results and discussion of interviews with a number of members of ministries of the Chilean state, the Nuble River Vigilance Committee, mayor, public servants, and local actors of San Fabián de Alico, and 
one member of power company based in Santiago, the capital city. It addresses the narratives each stakeholder holds on water issues, and how these narratives shape the way discourses are prioritised regarding the opinions of those involved in this research. Furthermore, this chapter discusses decision-making on the Nuble River, and explores the power relations that arise in water management in the country.

Chapter six contributes to drawing out conclusions based both on the work in previous chapter, and on literature, and the data. This final analysis chapter examines the effects of the narratives of treating water as a tool for development, and the main lessons from this conflict.

Chapter seven reviews the results presented in chapters five and six. It syntheses the value of my research questions and framework, addresses some of the limitations identified following the fieldwork and analysis, offers suggestions for further research. It ends with some recommendations, and further research possibilities. 


\section{Chapter 2}

\section{Research design: Introducing the methodology}

\subsection{Introduction}

This chapter provides an overview of the research design and how the research was conducted. It begins with a discussion of the theoretical framework that has shaped it and the methodology adopted. The research methods used are discussed, as well as the reasons for selecting the Nuble River and Chile as a location. Finally, the chapter concludes with a consideration of relevant ethical issues and limitations experienced during the time spent in the field.

\subsection{Philosophical approach to the research}

A piece of research incorporates multiple layers of expression, representation and interpretation. The way in which all of these layers are incorporated into research requires careful treatment to frame the investigation. By doing so, researchers are able to make explicit their experiences in the field and explore how these experiences affected their final results (Winchester, 2005).

Increasingly, the use of qualitative research has been employed to explain the interface between human beings, their environment and development, which is the case in this research. 
The exploration of ways in which people experience transformations in their everyday life is a cause of attention when creating knowledge (Howitt \& Stevens, 2005). The ontological and epistemological position of the researcher frame the overarching aim of the research, what questions are asked, the manner in which they are answered and how the results are analysed (Crang \& Cook, 2007).

Thus, the process of how this research was carried out is as important as the outcomes of the research itself. The following section outlines the adopted philosophical approach for the present study.

\subsubsection{Social constructivism, discourse and power}

This research adopts a social constructivist approach. Instead of searching for universal truths it acknowledges that a phenomenon is historically and socially situated. Social constructivism, as LeCompte and Schensul (1999) pointed out, assumes that "what people know and believe to be true about the world is constructed-or made up-as people interact with one another over time in specific social settings' (p. 110). Constructivists, then, disagree with the positivist concept of universal truth, believing rather that understanding of the social world is socially constructed (Mikkelsen, 2005, p. 184).

The epistemology underpinning this research aims to explore different meanings of a problem shaped by conventions of language and other social processes (Denzin \& Lincoln, 1994). Social processes are understood in a specific context through discourses that represent individual ideas, a key fact for this thesis. Nowadays, when trying to understand different voices and ways to explore environmental and social issues, social constructivism appears as an epistemology which can link the sciences and the humanities in academia as a tool that questions the assumed objectivity of knowledge (Demeritt, 1996). This point is particularly relevant in the Chilean context due to the technocratic approach to water management that has resulted from the neoliberal agenda and has fashioned the interaction between nature and society for decades. Therefore, a social constructivist approach allows this research to include the claims of people outside "the experts" to influence "both the character of scientific understandings 
upstream and the particular political outcomes that may result from them downstream in legislation or administrative law rulings' (Demeritt, 2001, p. 309).

In addition, discourse is understood in this research as 'a set of statements that help to constitute objects and subjects which aim to identify discursive practices' (Potter, 2008, p. 218). Bearing this in mind, this research has a Foucauldian approach to examine the relationship between social systems and discourse and the meaning of this relation (Howarth, 2000). Thus, common perceptions and understanding are primarily used as devices for specific purposes that "need to be placed in relation to other social objects, such as the state economic processes' (Howarth, 2000, p. 3). This Foulcualdian perspective is critical to comprehend the relations of power in social relations when conflicts on decision-making arise (Robbins, 2012). Studying discourses and narratives of each stakeholder involved in the Nuble River conflict helps to address the research questions from a historical and social construction of power.

The conflict in the Nuble River involves the articulation of different meanings of the river uses by the stakeholders involved. This research recognises that there is a world out there which is objective and but can only be known subjectively. The different meanings and assumptions of this world are individual in essence but collective in the end. Therefore, discourses through which individuals shape communal objectives are core to this research, and that is why social constructivism is an appropriate epistemological approach.

\subsubsection{Positionality}

Approaching this research from a social constructivist perspective means that I need to clarify my own perception of the reality involved this research, and how it has influenced the outcomes. This research seeks to explore the vision of those interacting with nature situated within a broad social and political context that is firmly tied to my own background and position. I chose the Nuble River as a location to analyse this interaction mainly because this river is part of my roots, as it is located close to my hometown in Chile. People from my city are called nublensiños, derived from the river. I became aware of issues and effects of water 
management when I worked as an agricultural engineer in the region as I mentioned in the introduction chapter. In particular, I saw how "hidden" processes affect relationships with nature both in the way nature is managed at different scales and in how it affects individuals and communities.

However, returning to Chile for fieldwork posed several dilemmas in negotiating 'field versus home' (Sultana, 2007, p. 377). It meant that there were buried tensions, and some participants felt my presence as an odd mix of being both an insider and an outsider (Mullings, 1999). This raised questions related to some assumptions about my identity. These assumptions play a central role because, as England (1994) argues, research is 'intensely personal' (p. 87) and therefore since my first interview I was aware that my positionality was important and influenced how I conducted my research. This led me to try to be careful to present myself as an equal, showing an understanding of issues in rural areas in Chile by my previous work and experiences, as well as equal with those working in decision-making spheres. Situating myself with my own values and beliefs on the subject investigated legitimated me to remove or diminish some hierarchy or uncertainty between the researcher and the participants. Considering my positionality in front of my interviewees could be considered as a 'sense of failure' (Rose, 1997, p. 306) in generating information, but this is a core part in the process of reflexivity and as strategy for situating knowledge. It allowed me to avoid false expectations around the neutrality of knowledge exposed in much of academic literature (Hay, 1998).

Being clear about my motivations to the participants from the beginning helped me enormously to provide a space of trust, recognition and respect for a conversation of mutual cooperation and participation. How these motivations encouraged those being interviewed and the type of information they could reveal was an important part of my fieldwork. Echoing Kobayashi (2009) 'the production of geographical knowledge is more than simply the "location" of knowledge - it involves the act of situating, and thus positioning, embodying, and engaging the knowing self and the known other' (p. 821). 


\subsection{A qualitative case study}

The methodology chosen had a direct influence on the methods chosen. Hence, the following section will explain how, according to my philosophical stance and positionality, I conducted this research and the implications of it in the final results.

\subsubsection{Qualitative research}

In geography and other related fields (such as development and environmental studies), the use of qualitative research has become an opportunity for researchers to engage with people and their surroundings in subjects relevant to them. Interacting, sharing, and understanding their local context gives an opportunity for geographers working with qualitative research to explore different issues (Winchester, 2005). Therefore, I have chosen a qualitative ethnographic approach which has a 'strong emphasis on exploring the nature of particular social phenomena, rather than setting out to test hypotheses about them' (Denzin \& Lincoln, 1994, p. 248). It is rooted in the concept of culture, of how people think, believe and behave, situated in local time and space, and influenced by its political, economic and social context (LeCompte \& Schensul, 1999). In that sense, ethnography must hold an anti-essentialist point of view as it tries to understand the dynamics and complexities of the situations it studies, avoiding "timeless" and "homogenized" images of cultures and societies, and must look at the field sites as interpenetrations of the local and the global, where people have continuously changing identities (Brockington \& Sullivan, 2003). In addition, ethnography looks at cases of investigation which facilitates data analysis and helps to interpreted the meanings and functions of human action (Denzin \& Lincoln, 1994).

Thus, an ethnographic methodology allowed this research to explore and interact with stakeholders in a way that enriched the communication and the production of knowledge valuable for them and for broader academic debates. 


\subsubsection{Case study}

I have chosen a single case study as a focus for my research as Denscombe (1998) notes 'to illuminate the general by looking at the particular' (p. 30). The selection of this case study originates from my own personal interest and previous work experience with small farmers in the Biobío region, my links to the Nuble River, and the way in which in the Nuble River are crystallised broader tensions and discourses.

Bradshaw and Stratford (2005) suggest that when a case study is selected they 'are deemed typical on the grounds that these will provide useful insights into causal processes in other contexts' (p. 73). Bearing this in mind, my chosen case study is critical to reveal the dominant neoliberal discourses that have been influencing water management decisions in Chile and beyond.

I was interested in critically exploring society in relation to water management, in particular in this neoliberal era given that Chile is one of the first and more radical examples of the adoption of neoliberalism and the comodification of water, which makes this study very pertinent and relevant in theoretical terms. Also, my previous experience led me to an interest in how water management is seen by a group of people when different understandings are faced.

This aligns with the social constructivist approach adopted in this research in terms of revealing the meanings and experiences of people in a particular context that can inform broader processes in different places.

\subsection{Research methods}

To address the specific research questions posed in this study from a social constructivist position and with an ethnographic case study, I adopted three methods: semi-structured interviews, participant observation and the use of secondary texts (including newspapers, grey literature, and magazines). 


\subsubsection{Semi-structured interviews and choice of participants}

I believe as a researcher that it is necessary to interact and understand diverse relations of nature and society in a particular place, exploring some events, incidents and practices that make this relationship. Semi-structured interviews are conversations between two parties, and it is a specific form of human interaction in which knowledge evolves through a dialogue' (Kvale, 1996, p. 125). It allowed me to analyse a range of topics, feelings and opinions with open-ended questions that promotes the participants' personal reflection (Kitchin \& Tate, 2000). Semistructured interviews also have the benefit of being flexible enough to explore other issues or interests that arise with interview participants, according to the flow of the conversation (Kitchin \& Tate, 2000).

Semi-structured interviews permitted me to explore ideas and links among the stakeholders involved in the conflict of Nuble River. Overall, 17 semistructured interviews were conducted over a period of two months (March and April of 2012). Six of them were members of regional and national government agencies, one was a member of a NGO working in conservation and sustainability, seven interviewees were from San Fabián de Alico (two from the local government and the rest part of the civil society), one was a member of a power company, and one a lecturer of the school of Geography at University of Chile working on political ecology. Table 2.1 provides a list of participants and their institutional role.

Participants were selected based on their role in the four groups of stakeholders involved in the dam project. A snowballing technique was used to select some participants according the suggestion of the stakeholders, the review of the relevant texts (mainly newspapers and social network website), or simply by the interest of others to be part of this research, especially those living nearby the area of study or in the region. The first group included local actors and local authorities from San Fabián de Alico, district in which the dam project is being planning (area of study) who oppose the dam. They were local residents as well as non-local residents working there or with strong links with the area of study. I also 
incorporated organisations from the civil society, small tourism entrepreneurs and local authorities.

Table 2.1 - List of Interview Participants

\begin{tabular}{|l|l|l|}
\hline Name & Type of Organisation & Location \\
\hline Ibor Borguero & INDAP & Chillan \\
\hline Beatriz Bustos & University of Chile & Santiago \\
\hline Juan C. Bustos & Local Committee & San Fabián de Alico \\
\hline Nelson Cortés & SEIA & Concepción \\
\hline Enrique Concha & Local Committee & San Fabián de Alico \\
\hline Cristian Fernández & Local Council & San Fabián de Alico \\
\hline María I. Fernández & Enerplus-Power Company & Santiago \\
\hline Vladimir Fuentes & Local Committee & San Fabián de Alico \\
\hline Marcelo Jelvez & INDAP & Concepción \\
\hline Margarita Letelier & Ñuble River \\
\hline Vigilance Committee & San Carlos \\
\hline Modrigo Lopez & NGO & Concepción \\
\hline Mauricio Morales & Local Committee & San Fabián de Alico \\
\hline Andrés Muñoz & INDAP & San Fabián de Alico \\
\hline Bolívar Ruiz & SEIA & Concepción \\
\hline Pablo San Martín & GORE & Concepción \\
\hline Jaime Yáñez & C.N.R. & Santiago \\
\hline Pablo Zambrano & Local Council & San Fabián de Alico \\
\hline
\end{tabular}

A second group was composed of regional and national government authorities from relevant bodies and decision-making institutions. It included the National Irrigation Commission of Ministry of Public Works, the Institute of Agricultural Development (an agency administered by Ministry of Agriculture), the Biobío Regional Government, and the Service of Environmental Impact Assessment of the Ministry of Environment. In addition, I interviewed the Head of Communications and Community Management of a power company named CGEENERPLUS, one of the private power companies interested in the dam project. The last group of stakeholder participants included the Nuble River Vigilance Committee, an association of irrigators (large farmers) who are pushing toward the 
construction of the dam to provide water for their irrigation systems and agricultural production.

The semi-structured interviews were organised around ordered but flexible questioning. The structured part of this technique helps reduce some biases on the emphasis of some topics that the interviewee wanted to emphasise, and provides a relatively organised recollection of data for a latter analysis (Kitchin \& Tate, 2000).

All of the interviewees chose the option of using their real name in the consent form of this research. Their public involvement on issues surrounding the Nuble River makes reasonable that option. The consent form, information sheet, and interview schedule were obtained following the guide and principles of VUW human ethics committee policy (see Appendix One).

\subsubsection{Participant observation}

As a way to understand how people live in the context of their everyday life, ethnographers have utilised participant observation. One of the advantages of this method is that it allows the researcher to be involved in activities related to the research topic in order to access other ways in which the research participants express their ideas and work. However, this technique is highly demanding and there are other considerations to take account. First, becoming a "participant" involves 'an immersion of the researcher into the everyday rhythms and routines of the community' (Crang \& Cook, 2007, p. 37). This was challenging for this research because I am not from San Fabián de Alico and I did not have direct links with this community. Therefore, it required time to develop networks and trust. Second, being an "observer" implies sitting back and deciding which activities to engage in. It was important to avoid the apparent authority of the academic expert arriving and analysing this particular society as a portrait. Instead, my aim was to interact, with a certain degree of autonomy, to get an insight into 'the dynamics and history of the people studied' (Scheyvens \& Storey, 2003, p. 66) in mutually beneficial ways. 
By observing the participants and how they communicate their ideas, the use of body language, the attitude of each participant and how they talk to each other was important. It permitted me to engage through "gatekeepers" to get involved in two events of the local community of San Fabián de Alico. Although, they were not related to the conflict in the river, these events (one folklore music festival, and the opening academic year at one primary school) allowed me to engage with locals and explore the role of some participants of this research within the community. Also, I was invited to a meeting with the directory of the Nuble River Vigilance Committee dealing with the dam project, where I also explained the objectives and scope of this research. These events helped me to establish contacts and build trust in a short period of time. Also, the connection between this district and my hometown (the main city in the area) created common stories and roots which in my opinion facilitated my introduction with participants. Finally, this sort of ethnography gave me an indication of the degree of concern the participants held, the politics involved, and other sources of information related the case study.

\subsubsection{Secondary texts}

In order to have a broad and well informed idea of the project and its conflicts, I drew on and analysed the opinions and thoughts given by the stakeholders in the media and grey literature. Reports and articles from newspapers (local and national), radio, TV interviews, internet, blogs, social networking and any other sources of information were considered. The challenge of this approach is to collect relevant information of the topic of study, but it enabled me to explore the complexities of how issues are represented, and how representations change and simplify issues over time.

\subsubsection{Coding and analysis}

Because this research is about the narratives people construct in relation to a conflict, I undertook a discourse analysis (see section 2.2.1) to analyse my data using both deductive and inductive coding techniques. How the people act, respond, think, and perceive the world is constituted through a linguistic 
description of the world (Waitt, 2005). Human geographers have emphasised this Foucauldian view to investigate ways that different truths construct the tension between the biophysical and non- biophysical world. This approach has challenged other disciplines to take account of excluded voices, such as indigenous, peasants and gay movements. Moreover, other scholars drawing on this approach have found it useful to reveal social marginalisation in processes of environmental management (Glesne, 2006).

Considering the research methods and the kind of sources used in this thesis (semi-structured interviews, participant observation, secondary texts), Waitt (2005) suggests that 'discursive formations emerge from a coherent pattern of statements that can be identified across a range of sources' (p. 176). Thus, it is necessary to scrutinise the structure of discourses to enhance my analysis. Coding helped to clarify key themes in the structure of narratives and allowed me to systematically examine how new knowledge emerged from my sources (Creswell, 2003). This is an iterative process during the whole analysis that implies inductive and deductive procedures (Creswell, 2003). In particular, I found data inductively from the narratives of the participants, as well as deductively from the literature that I used in relation with my research questions.

Throughout the process of using a Foucauldian discourse analysis, it is clear that it is a non-linear process, but rather it engages in a cyclical analysis trying to answer questions and narratives that in turn raise further questions for exploration.

Finally, I have translated all the interviews from Spanish to English as I have transcribed them. So, it is important to take in consideration this language barrier, as well as any effects this may have had on my research. 


\subsection{Ethical considerations}

Ethics have become a key concern in the last decades specially when research involves human participants. However, ethics in research for some must be linked to the approach of ethical development as a way of rethinking development (Qizilbash, 1996).

Victoria University requires students engaging in primary research with human participants to gain ethical approval, allowing the researcher to address ethical considerations.

This is particularly important to bear in mind when ethical and thorny dilemmas are encountered in the field. However, ethics involve on-going reflection and negotiation, because while problems are confronted and solved, new conflicts are being born (Qizilbash, 1996).

\subsubsection{Ethical issues and relationships with contributors}

The main issues that I faced were related to my own opinion and self representation. As explained in section 2.2.2, my positionality played a key role in terms of getting participants interested. The fact that this research is done through an overseas university allowed me to facilitate a frame of distance and closeness at the same time.

Many of the participants were contacted before my trip through gatekeepers close to them. Therefore, I was not labelled as stranger but instead, "a friend of a friend" doing research. I think this explains why interviewees were keen to meet with me in different circumstances, from a national head of a programme within a ministry in the capital city to another facing the potential flooding of his/her land.

Finally, two of the key contributors of this research posed difficulties to be involved. In one case, the participant of the direct ministry involved in the project did not allowed me neither to record the interview nor take notes, and the other (regional manager of the institution managing water) did not answer my several emails and calls for a meeting. Notwithstanding, the level of contribution of others to this research was very valuable and provided high standard information. 


\subsubsection{Victoria University of Wellington code of ethics}

Following the procedures that Victoria University of Wellington requires students to consider and address the ethical implications of their research. In accordance with these requirements, each participant of this research was provided with an information sheet and a consent form (see Appendix One) prior to the start of the interview. These forms explained to the participant who I was, what I was researching, the reasons I was interested in interviewing them and the use of the information collected.

By signing the consent form, participants acknowledged that they had been provided with information on the research and were willing to take part. Participants were offered the choice between using their own names or a pseudonym (see table 2.1). Surprisingly, all of the participants were happy to use their own names in the research. Therefore, in the following chapters participants' statements are identified with their real name and institutions that they represent.

\subsection{Summary}

This chapter has shown that this research is situated within social constructivism using discourse analysis of research participants' opinions. Utilising semi-structured interviews, participant observation and analysis of secondary texts interviews to map the perceptions and experiences of those involved in the conflict investigated, allowed finding different perspectives and points of conflict.

In addition, this chapter pointed out some of the issues and complexities of the research, which might have had potential impacts on the research results. Positionality, analysis and ethical considerations were also discussed.

I was a local researcher and this helped me avoid many problems. However,

some challenges still remained. I learnt to stay flexible and focused in terms of research design, methodology, and methods with a view to dealing with every possibility and changes in the field. Despite some challenges, the interviews with 
informants ended satisfactorily. The research findings were reinforced and enhanced by my understanding and perception of my home country's tradition, culture and contexts. 


\section{Chapter 3}

\section{Approaching water considering the literature}

\subsection{Introduction}

In order to address the objectives outlined in chapter one, this section provides an overview of the relevant literature to set this research in an appropriate theoretical framework. Given the problem outlined in chapter one how is water understood and managed as a tool for development - it is clear that there are four key areas of literature that require exploration.

Firstly, a discussion of debates around key concepts on development studies is presented. In doing so, the appearance of the neoliberal paradigm as a project and ideology in development is analysed. Secondly, the current trend that explores the encounters of neoliberal ideas and nature is reviewed. This is conducted by discussing literature on neoliberal natures considering the different meanings and drawbacks of these encounters. Thirdly, an overview of the controversial and resisted Chilean Water Code is provided. This Code has been the main tool for water management in the country in the last 30 years and it has been criticised mainly for two reasons: the market approaches to allocate water rights, and the poor public participation on decision-making. Thus, the Water Code has created uneven water allocation whereby inequality of development appears, especially in rural areas (Budds, 2004; Carruthers, 2001). Finally, this literature review offers an overview of the evolution of the hydro-social and techno-nature paradigms among social geographers. These approaches are increasingly being used to understand the relation of waterways and the human world, in order to 
analyse the engagement of a particular society when water projects are being assessed, and how these projects create different discourses of governance, participation, power, and emotions. All these elements are present in the Nuble River case, and will be considered as part of this research.

Bringing together these bodies of literature, this research aims to provide an original and nuanced perspective to study the current situation of the Nuble River. Thus, this research aims to make a contribution not only to a better understanding of this particular conflict, but also to the Chilean water management system and to broader water management discussions.

\subsection{Contextualising development}

The concept of development is contested. It is not my intention to situate my research in one development approach in contrast to another, but rather to explore the understandings around development, and how this concept has shaped societies and countries worldwide.

In the Geography field, development has been considered in many studies encompassing the ideas of economic, political, and social progress in one hand, and as referring specifically to intentional programmes on the other hand (Brohman, 1996). Taking this view, the complexity involved in development is how to address its meaning in an appropriate way, especially where this involves human beings and their environment. This has been a major challenge for development practitioners as well as many geographers. Willis and Kumar (2009) suggest that those practitioners in development have focused their studies on how and why development varies across space, how this has challenged power relations, and how the scale of intervention has been experienced at different levels.

These areas of interest are shared for those researching environmental issues overlapping with the perspectives of development studies in many fields. This reflected in the aim of this research, in terms of exploring the use of 
development and environmental struggles as a discourse through which many projects have been supported with tangled and mixed results in the global north and south, and in urban and rural areas (Chambers, 1997). Various development discourses and projects have been proposed by academics, experts and politicians, some emphasizing social conditions, others environmental issues, but most of them, prioritising economic aspects. Among them, one of the most compelling sets of ideologies and practices that have been foundational to recent development projects have been neoliberalism which will be explored in the next subsection.

\subsection{Origins and tenets of neoliberalism}

Based in liberal economic ideas dating back to the Enlightment in the $18^{\text {th }}$ century, neoliberalism revisits calls to promote individual and moral rights independent from governments (Chambers, 2005). Economists working at The Chicago School of Economy, led by Milton Friedman, reworked these ideas and reformulated them both as a policy programme and political project (Brohman, 1996).

Moving away from Keynesian ideas of state welfare, for Friedman and those at the Chicago School, the key was not stability of fiscal policy (or government spending) but monetary supply. This means that for them, low inflation and interest rates would ensure the right signals were sent to markets. Also, they argued that central banks had to be independent of governments to ensure free operation of the market (Bondi \& Laurie, 2005). These key concepts plus the historical context in the late 1970s, created perfect conditions to set this ideology and policy programme into action. Moreover, this became a dominant model for economic and governmental management adopted by many countries, and reshaped how individuals and society views welfare and prosperity. These far reaching changes implied a new political order worldwide, a new role for the State managing common resources, new opportunities and barriers for individuals, the influence of technology, and so on (Castree, 2008b). But, most importantly neoliberalism 
reshaped the way in which society and environment interact. This last point is key in this research, as well as for other scholars studying the effects of neoliberal policies on natural resource use.

The oil crisis during the 1970's saw the introduction of new thinkers pushing for a new economic model. They sought to deregulate the market and argued for less intervention by the state as a way to promote free trade (Desai \& Potter, 2008). The Keynesian idea of state involvement in the economy was criticised by these groups who wanted a more "modern" role for the state. For them, the Keynesian state that looked after the well-being of citizens was not adequate in this new world context, so new forms of political-economic governance were necessary (Larner, 2000). Thus, the shift was through privatisation and deregulation over the welfare structure of the state.

A number of conditions facilitated the adoption of neoliberal ideals around the world. First, conservative governments in the North viewed this approach as a way to solve internal, and also, external economic problems of their countries. The UK and US, under the Thatcher and Reagan administrations respectively, adopted these ideas promoting concepts of commercialisation, privatisation, marketization, and commodification as central in their governments agendas (Bakker, 2010). Second, in the early 1980's many developing countries announced that they could no longer pay debts to northern financial institutions, creating an enormous fear towards an imminent collapse in the whole international bank system. As a consequence, the key organisation charged with addressing the debt crisis was the IMF or International Monetary Fund (Craig \& Porter, 2006). As a response to these situations, new international policies were launched. The most notorious was the introduction of Structural Adjustment Programmes (SAPs) to indebted countries, which aimed to boost economies mainly through cutting state expenditure, reducing state intervention, and promoting liberalisation and internationalisation of trade (Desai \& Potter, 2008).

All these neoliberal features resulted in a notable improvement in trading between northern and southern economies, which produced an enormous benefit to 
the agricultural sector in global south countries that began to export their goods and products at a rate not seen before. It also affected local economies because rural areas were the main producers of agricultural and raw goods, creating improvements in labour markets for males and females (McCarthy \& Prudham, 2004). There were simultaneous efficiencies in land production as a result of the increased property rights that neoliberal policy proclaimed. Communitarian tenure systems were replaced with a system that viewed land as an essential commodity necessary for market exploitation (Liverman \& Vilas, 2006).

Open markets increased opportunities for new business and supported the emergence of new entrepreneurs in the industrial-export sector. This was also reinforced by the export-oriented policies of neoliberalism, as well as being underpinned by the self-regulating market (McCarthy \& Prudham, 2004). Banks and financial systems allowed new credits for ordinary people to have access to loans and to benefit from them in these new economies where everyone take part. Flexible labour markets under neoliberalism were central to increased rates of women working in many different areas of the economy (Peck \& Tickell, 2002).

Other scholars have proclaimed that neoliberalism has established new forms of governance by processes of decentralisation. Bakker (2005) has highlighted the beneficial impacts in water supply systems in the UK which have achieved better management and increased awareness in the way of population uses water. Also, Budds (2004) argues that the decisions to use natural resources have involved different actors, from national to regional and to the municipal level. In addition, studies by Robbins and Luginbuhl (2005) suggest that neoliberal water management and forestry sectors (among others) have experienced considerable efficiency in their use. This has generated good returns in investments, but more importantly, income and improvements in livelihoods. Then supposed win-win scenarios would be possible under the neoliberal nature approach (Duffy, 2005). However, the impact of neoliberalism on the environment has also been questioned. Most studies have focused on the uneven consequences and the concentration of profits in the hands of a few. Nevertheless, this is highly 
contested terrain in all of the aspects mentioned above and, as will be seen in this research, neoliberalism manifests in many different nuances.

Therefore, in order to better understand the adoption of neoliberal theory for development in a critical way, this research will now explore how neoliberalism has influenced and managed strategies in the environmental field. Neoliberal human-environment relations have been described by some as the neoliberalisation of nature, or just neoliberal nature (Mansfield, 2004; McCarthy \& Prudham, 2004; Perreault \& Martin, 2005) and is the subject of the next section.

\subsection{Neoliberal nature}

The effects of neoliberalism on nature have been addressed by scholars of environmental management and development studies, mainly from a political ecology perspective. Studies by Bakker (2003, 2010), Castree (2008b), Mansfield (2004), McCarthy and Prudham (2004) and Larner (2000), among others, have considered the consequences of the encounters between neoliberal ideas and nature. For them, these encounters have led to contradictory results in the context and scale where they occur (Peck \& Tickell, 2002).

The idea of the conceptual separation of nature and society proposed during the enlightenment and the scientific revolution in the West consolidated the early attitudes to conservation (Cronon, 1996), and has been taken for some (Bakker, 2010; Castree, 2005, 2008a, 2008b; Larner, 2000) to explain the instrumental ethic though which neoliberal ideologies and practices address nature. The assumption here is that discourses of a market approach to the use of natural resources have been "normalised" under neoliberalism, allowing their exploitation. Thus, these discourses have influenced Western and non-Western nation-states in decision making processes, regulation and policy frameworks in how they treat nature.

Given how central privatisation has been in water management, it is discussed further here. Bakker (2003) and Swyngedouw (2005) have emphasized 
that the privatisation of water, whether in urban or rural areas, has reconfigured the hydro-social landscape. For them, historical events (the period post World War I and the global recession after the oil crisis in the 70's to mention a few) and international agreements such as the Dublin Principles in 1992 and the Kyoto Declaration 2003 have altered the way water is managed (Bakker, 2003). Water management now occurs through public and private interactions, and both sectors aim to have good environmental standards and good returns provoking a tension in the commodification process (Swyngedouw, 2005).

The state and the private sector have become very interested in adapting the demand for water into their objectives. Consequently, artisanal ways of water management conducted in most rural communities are no longer deemed efficient and those who value sustainable livelihoods are outside dominant discourses (Sultana, 2011). Those local views are neither part of the elite nor part of narratives where water is deemed a necessity for the development of a country. Then, these discourses are silenced in efforts to materialise projects such as the dam on the Nuble River, leaving behind communal and ancestral ways of using water. This implies changes not just in the use of water, but also, in the environmental institutions and the ways of planning development on the ground.

Other authors have emphasised different aspects of the neoliberal nature approach and tended to be more critical. McCarthy and Prudham (2004) point out that neoliberalism changes the relations between society and biophysical nature. Hence, rural communities have suffered social and environmental transformations as new forms of environmental governance have emerged. This concern is supported by Budds (2009) who has found that power relationships play a key role when projects about natural resources are being assessed. Larner (2000) further critiqued the pace at which neoliberalism puts aside local ideas creating social inequalities. Other studies have highlighted the importance of local resistance as a way to shape specific management approaches (e.g., conservation) to be applied when local and global bodies are involved in order to maintain some sense of selfdetermination (Duffy, 2005). 
More important, the introduction of payments and systems of monetary valuation in the use of natural resources are suggested as the key point for studies analysing neoliberal measures. There have been particular studies that stress this point. Liverman and Vilas (2006) suggest that these practices mentioned have provoked radical changes in society, especially in Latin America. Moreover, neoliberalism permanently drives profit seeking behaviour so it has set the tools and knowledge within different societies with local features. This is explored by Mansfield (2004) who shows the rationale of neoliberalism to harness profits by seeking efficiency in environmental solutions. In this manner, countries have forgotten possible solutions to conflicts between conservation and development, such as traditional indigenous knowledge and indigenous approaches to nature.

Further encounters between neoliberalism and nature and its tensions are exposed in the next section in particular with regards to the case of the water market in Chile and its impact on rural communities facing water access issues.

\subsection{The neoliberal Chilean water market}

The Chilean state adopted radical policies in the agriculture sector as a way to achieve economic growth. Thanks to the natural conditions of the country the military junta privileged the exploitation of the natural resources to generate incomes (Liverman \& Vilas, 2006; Murray, 2002). Here water became crucial to develop this new economy because this resource it is the engine of the natural cycle for crops, as well as for hydropower dams, the main source of energy of the country.

However, the problematic distribution of water, the intensification of agriculture, as well as the natural scarcity in some areas put pressure on water management. It had been seen as a "free" resource, and so some people have had access to it while others have not. It is important to take account that the reasons for scarcity is variable - in some places scarcity is caused by power and politics , 
so scarcity is socially constructed and in other places it is much more associated with climate.

In this sense, a usual neoliberal policy introduced in many countries has been the use of tradable water rights to boost the care and sustainable use of water resources. Such policies follow the four core points raised in the Dublin Principles: 'care for the environment, increased participation of non-governmental stakeholders, sensitivity to gender issues, and the increased role of markets' (Budds \& McGranahan, 2003, p. 91). Thus, water has been converted into an economic good, that can be more efficiently managed (Bakker, 2005). Here, water rights were promoted under the Water Code established in 1981, which has enabled water rights to be traded on the market (details about what the Water Code is and how it is neoliberal, who and in what context it was established are discussed in chapter four). This policy was created by economists who graduated from University of Chicago as known in Chile as the Chicago Boys (Galaz, 2004). Under the structural adjustment programmes in Chile, the Chicago Boys created the conditions to develop neoliberal policies boosted the protection of individual rights over collective rights.

Certainly, those economic adjustments prompted new trade agreements with northern countries which transformed the Chilean economy. They provided a source of raw materials and natural resources from the "periphery to the centre". One of the most privileged sectors was agriculture which improved its production and export sales from the mid-80's, encouraging dramatic growth in the national economy (Challies \& Murray, 2008).

As mentioned earlier, water management is governed by the Water Code and confers management to one specific department, the General Directory of Water (DGA, Direccion General de Aguas). While the Water Code remains contested (discussed further in chapter four), another dimension that this research engages with is the role environmental institutions play in water management.

The lack of coordination and different criterion within different departments of the state assessing water projects and their impacts on the nature is a problem 
associated with water governance. The procedures and discourses in which different institutions allocate water have received little attention in the literature related to Chilean water management. Instead, studies have exposed the circumstances of the creation of the environmental framework within the Chilean state and its drawbacks assessing nature (Carruthers, 2001; Prieto \& Bauer, 2012; Tecklin, Bauer, \& Prieto, 2011). However, these studies are important as well in trying to recognise the market logic behind the institutions in Chile.

In the case of the national environmental commission or CONAMA (Comision Nacional del Medio Ambiente in its acronym in Spanish) it was created after the return to democracy in 1990 and its first mechanisms and policies were designed by 1994. Key elements of these new apparatus in the Chilean state were based in neoliberal concepts. In this regard, the new toolkit for environmental institutions was underpinned by a premise of payments for services as the most efficient means to attain the sustainable use of natural resources (Mansfield, 2004). In addition, Carruthers (2001) and Tecklin et al. (2011) suggest that this environmental framework set in the Chilean state is a response to introduce the country into the global market. Indeed, these reforms followed the rules imposed for the global north countries to export goods. So, the logic within this new legal framework responded to protect natural resources under the assumption that natural resources would be better managed through private property.

Furthermore, the creation of environmental institutions in Chile illustrated that establishing the neoliberal model in Chile was beyond the military dictatorship (Carruthers, 2001). In fact, after the soviet bloc collapse the neoliberal paradigm was seen as an uncontested project in politics. Hence, the new political parties in power after the Pinochet dictatorship deepened the model both in the mode of production of raw material as well as the nature-society relation within the country. 


\subsection{The problematic efficiency of the Water Code: Access for all?}

All these policies and programmes were supported by the military dictatorship of Pinochet without any popular consultation which resulted in rapid socio-economic changes (Perreault \& Martin, 2005). These measures brought harsh consequences in rural areas, especially for peasant and indigenous communities. They were not familiar with this privatised regime and its rules, especially using water. As Boelens (2009) and Budds (2004) argue in their works on the Chilean water management model, the separation of water and land, the downsizing of the state and its role as an "observer" of free market operation, and the new rights for the most economically powerful buyers, dramatically changed the social-natural rural landscape. In addition, Gentes (2008) observes that the core idea in the neoliberal framework seeks to undermine communal ideas in managing natural resources. As a result, individualistic enterprise takes place, looking to make profits in this global market (Gentes, 2008).

Some business sectors such as mining, hydropower, and forestry benefited from the Water Code most. They could purchase large quantities of water rights, and push informal water users like peasant communities aside. In this way, as Boelens (2009) explains, big companies 'seek ways to motivate all water users to register their rights and they drive public policy geared to making users participate in water rights trading' (p. 320). Thus, other water uses like customary rights (common in indigenous communities) are registered and become part of water trading, affecting the autonomy of groups and limiting alternative forms of water management.

There are hidden effects under these homogeneous rules and organisational structures that affect most communities. Social networks of contacts, informal norms, social positions, and the privilege of trading goods and resources between new neoliberal entrepreneurs and the military authority, increased uneven access and control of water (Garande \& Dagg, 2005). The top-down approach in decision- 
making, the communication channels, and the poor participation at the community level perpetuated these social effects and continue to this day (Boelens, 2009).

In addition, studies by Budds (2004, 2009) and Galaz (2004) question the goals behind the Water Code pointing out that this resource was seen as a valued and limited resource, with a price, with responsibilities, with property rights, and they found that somehow this legislation increased poverty. Management under the Water Code treated all players in the water market as equal. As a result, peasant and indigenous families were seen at the same level as large-farm industries and transnational companies (Boelens, 2009). The reality is that water rights are disproportionately held by foreign mining, forestry and hydropower companies (Prieto \& Bauer, 2012). This suggests that in effect, the distribution of rights is not equitable and favours the larger players. While changes have been made to try to address these inequalities, the overall structure remains the same (RomeroToledo, Romero-Aravena, \& Toledo-Olivares, 2009).

As Bauer $(1997,2005,2010)$ suggests, the trade of water in markets did not have the effects expected. According to his studies, water efficiency and private control over use were improved, but trading has been limited as a result of legal and administrative complexities, and ambiguous or contradictory economic signals of price and value. Neoliberal models for measurement, economic valuation, and marketing of natural resources and ecosystem functions were the focus of these novel national environmental commission or CONAMA. McAfee and Shapiro (2010) and Larner (2000) declare that the purpose when neoliberalism encounters nature, is to show that the natural environment can be safely managed as a commodity. Thus, the commodification of nature occurs along neoliberal lines that determined a conceptual separation of nature and society (Bakker, 2003, 2010; Robbins \& Luginbuhl, 2005). As a result, nature is exploited and limited according to individualistic and human consent. Nevertheless, the last statement should be treated with great care because every neoliberal regimes varies in its practices and effects in time and space (Larner, 2000; Peck \& Tickell, 2002). 
From the foregoing analysis, it is clear that encounters between neoliberalism and nature have had important consequences in Chile, demanding additional studies in the field of political ecology to investigate the power relationships involved in the struggles for access to water.

\subsection{Linking the hydrosocial cycle, techno-natures and development terms}

Water is often linked with notions of development, mainly through the delivery of safe-drinking water. Also, water is associated with growth as a key factor for global human development, a goal expressed in the Millennium Development Goals (Sultana, 2012). This idea of water as a means to achieve development, supported by international organisations and governments, is often a hallmark of progress, and contributes to demonstrating that a country is under good administration (Sultana, 2012). International organisations have developed links with the private sector, and therefore have strongly influenced the expansion of private companies in the water market. For example, Bakker (2003) mentions four key characteristics of these links. For her, the scale of involvement of multinational companies, the amount of finance being mobilised via these companies, the ideological and the financial support from key international finance institutions, and finally water privatisation is driving development programmes to achieve safe water for those living in scarcity.

As a result, opportunities have opened for private companies to look throughout the world for suitable locations and/or projects to invest and gain profits through water management. As Bakker (2003, 2007) says, there are all sorts of types of privatisation and not all are full cost recovery. However, David Harvey (2003) and Erik Swyngedouw (2005) point out more generally that any form of privatisation or enclosure in the name of capital is accumulation by dispossession. Moreover, this has brought some consequences. As Loftus (2009) notes, there is 'a noticeable move between the study of how distribution of water 
has been shaped by relations of power and an analysis of how water itself shapes those relations' (p. 954). That is why using political ecology as a lens helps to address a broad understanding of dominant power discourses around the use and management of water.

For Swyngedouw (2004, 2009), Kaika (2006), Zimmerer (2011), and Castree (2005), the correlation between hydrological cycle at different scales and the relations of social power, political, and economic factors have been labelled as socio-hydrological cycle and it has been used to explain current trends in water management. The socio-natural relations of water and social power have been recently emphasised by geographers as an important field to investigate (Loftus, 2009; Sultana, 2012; Swyngedouw, 2009). Here, the discussion has centred on how water is seen by some as divorced of its socio-hydrological importance, and rather seen only in terms of the profits of others. As a result, under the lens of a sociohydrological cycle, water and social power are complexly interrelated, and the experiences of groups and communities facing water projects in their localities are highlighted.

This idea implies, according to Swyngedouw (2009), that the concept of the hydro-social cycle is applicable as a combination of physical and social processes that are entangled in a certain waterscape. Hence, water hybridises the socionatural encounters in an inseparable way which is key when trying to understand why water is much more important that a simple commodity. Also, particular attention needs to be given to power relations where hydro-social changes take place because there are winners and losers (Kaika, 2006). As Swyngedouw (2009) points out, 'processes of socio-environmental change undermine the stability or coherence of some social groups or environments, while the sustainability of others elsewhere might be enhanced' (p. 57). Hence, the current research aims to contribute to this task through the analysis of arguments and discourses about particular strategies of water use in the Nuble River. The case discussed in this research reflects the fact that interventions in the organisation of the hydrological cycle are always political in character and therefore contested and contestable' (Swyngedouw, 2009, p. 57). 
Water projects and technologies are embedded in development practices, policies and discourses. This implies that other unseen impacts associated with water projects (for instance, ecological and social) are being diminished, creating contested scenarios in the context of development. Water technologies and hydraulic projects have been produced and reproduced as signs of prosperity and modernity, which explains the large number of dams, flood control, and irrigation schemes financed by development organisations (Swyngedouw, 2004). In addition, these tend to be supported through water management schemes that result in complex power dynamics between institutions and private interests. Nevertheless, these dynamics have brought changes not just in waterscapes, but also in the nature-water-social relations. These changes in the nature-water-relations have been called "hybrid nature" as they comprise nature, culture, society, economy, technology, and ideology components (Bakker, 2010; Bennett, 2010; Kaika, 2006; Swyngedouw, 2004; White, 2006). Consequently, as Swyngedouw (2004) suggests 'material, representational, and symbolic practices are welded together' (p. 110) driven by the notion of modernity. In this vein, opponents to those water projects are challenging both the pace of development goals and the governance of institutions, creating uneven arenas of discussion and participation in decisionmaking. Therefore, as socio-ecological transformations in waterscapes take place, questions arise in relation to the inequitable power relations in narratives of water as a tool for development.

In addition, scholars have underlined aspects of participation and emotion in water conflicts. Here, Sultana $(2009$, 2011, 2012) has explored these issues in a study of groundwater usage in Bangladesh. Sultana claims that water projects usually take place with "pre-existing groups" as those require less investment in terms of costs, time, and are less likely to result in conflict (Sultana, 2009, 2012). Such approaches reinforce the idea of hierarchical and top-down decision-making which is common in rural areas with a history of patriarchal governance. In this context decisions are taken, validated by a so-called participatory process, and provide the legitimacy for governments to carry on with projects. Such processes challenge the idea of open citizen participation (Sultana, 2009). The meaning of 
participation varies in different contexts and places, and often reinforces social norms, especially for those that do not feel comfortable talking in public spaces or challenging existing power structures (Sultana, 2009).

Emotions and meanings are highlighted by social geographers working in development and environmental subjects to emphasise that struggles over natural resources are 'entangled and interconnected' (Sultana, 2011, p. 164) and to explain the ways that nature-society operates in any context. This is because access, use and control over natural resources come to expose the narratives that natural resources play in everyday life (Smith, Davidson, Cameron, \& Bondi, 2009; Sultana, 2011). Water, trees, land, fishing, and so on are part of daily economic activities in rural communities, far more than in urban centres. That is why in general, projects using these resources are highly contested by these communities.

Claims to natural resources are always about power and control. In consequence, access, use and control of them in a development terrain needs to be addressed by environmental management systems, especially within the water rights framework in the Chilean context. As Mehta (2003) has pointed out, control of water needs to be seen differently from access to water because control and access are associated with land, technology, ownership, and set in broad social relations. If access to water for those living around a river basin has to negotiated, control tends to be both ecological and social and located in the hands of a few. Here, the notion of neoliberalism in terms of 'hybridising' society and nature towards efficiency and profit making arises (Bakker, 2010; Mansfield, 2004), and is apolitical and in the hands of experts in water management. This is particularly the case in Chile under the Water Code. Under such a regime the politics, power relations, and livelihoods of marginalised groups remain invisible.

\subsection{Summary}

This chapter has presented a review of the relevant literature, focusing on the theory and practice of neoliberalism, both as a development paradigm and as 
an environmental project. Neoliberal discourses around development have been described and contested because it has brought uneven effects in social and environmental terms. Neoliberal ideas have been used by international organisations and many governments worldwide in their attempts to manage in a more "efficient and sustainable" way goods and communal services, such as natural resources.

Watercourses have been seen as a pillar for development everywhere around the world. Projects using its resources are often linked with modernisation and prosperity. Under the umbrella of the neoliberal governance of nature, the relation of nature-society has changed into a more technocratic view. As a result, different tools of water management have emerged and been implemented. For instance, the Water Code in Chile established that water is a tradable commodity, imposing exclusive property rights for those who partake in the markets. The technocratic neoliberal regimes over water management in Chile have been embedded in Chilean society since the 1980s imposing a discourse that depicts river basins as resources with low productivity but huge potential.

Within the wider field of development and environmental studies, slight attention has been given to address the different narratives participants use to explain development linked to waterways and their socio-ecological-economic importance at different scales. The concepts explained in this chapter, and then help to lay the conceptual foundations and provide the tools to address each of these areas when exploring the case of the Nuble River. Incorporating the neoliberal-nature literature together with terms such as the hydro-social cycle and techno-nature offers a unique and original perspective to analyse the case study. There is little evidence to suggest that they have previously been brought together both in Chile, and more specifically in the Nuble River. 


\section{Chapter 4}

\section{The neoliberal institutions in the Chilean context: Past and present}

\subsection{Introduction}

Having established the neoliberal character of current trends in water management this chapter turns to the specific context of Chile to provide an appropriate background necessary to frame this research. First, the chapter lays out the historic process by which neoliberal reforms were introduced in Chile. Then, it examines the main features of the Water Code and how it was enacted as the primary tool for water management. Finally, the chapter finishes by exposing the contested role of environmental institutions in Chile as the key means to component assess nature and projects using water. The context within which Chile's water management has developed over time is linked to both turbulent political struggles and the global economic drivers by which the country has shaped its model of development.

\subsection{Neoliberal reforms in Chile}

This research addresses the critical problem of how water is used as a tool for development in Chile. There is plenty of evidence to suggest that this understanding of water has shaped the current situation of the Nuble River. Yet, this particular case is situated in a broader and more complex context that informs how water management is understood in Chile today. 
At the beginning of the 1980's, Chile experienced a notable change, adopting neoliberal reforms as a model of development (Salazar \& Pinto, 1999). These structural transformations reached the whole society, but were mainly put forward by setting new institutions and legal frameworks in the country. The rapid introduction of these changes was due to the military regime that had been in power since the coup d'état against the socialist government of Salvador Allende in 1973.

The military regime or military junta broke a long history of republican sovereignty in which many governments from the whole political spectrum had been in power in a continuous democratic process from the beginning of the republic of Chile in the nineteenth century (Salazar \& Pinto, 1999). The military junta introduced strong measures that affected not just the economy of the country, but also led to social and political transformations. Some actions included the closure of the National Congress, and as a consequence all political parties; the abolition of work unions and of any sort of social movements; and media censorship. Strong economic changes were carried out through a Structural Adjustment Programme (SAP) later in the eighties (Desai \& Potter, 2008; Murray, 2009). Sadly, the death and disappearance of opponents to the military junta were part of the enforcement practices to impose the ideological and economic model pushed by the military junta. Fear was used to control the population and avoid a return to democratic rule or any participatory process of election and decisionmaking.

Furthermore, in 1980, the military junta chaired by Augusto Pinochet (a former military guard of President Allende) created a new constitution and introduced new institutional arrangements to establish Chile as a friendly freemarket country (Salazar \& Pinto, 1999). The constitution was tailored by the military junta to secure their power for another eight years with Pinochet as president, as well as it sought to develop the country. But most importantly, the constitution was influenced by a new economic and political project, neoliberalism, which was shaped in the United States but in practice appeared suitable to be implemented in a complex country such as Chile. Therefore, a new era in Chilean 
history began, focused on the implementation of a political-economic model that was intended to enable the country to overcome poverty and achieve "development". This model and emergent development programme could be put forward because of the extreme control being exerted by the military dictatorship that remained in power for 16 years (Salazar \& Pinto, 1999).

As was mentioned in the previous chapter (see chapter 3 , section 3.2), the neoliberal model emerged in the United States based in liberal and conservative ideas promoting the individual and moral rights independent from government (Chambers, 2005). Economists working at the Chicago School of Economics, led by Milton Friedman, reworked these ideas and reformulated them both as a policy programme and political project (Brohman, 1996). Due to the oil crisis in the 1970's, liberal ideas were revitalised and rearticulated as the solution to solve the worldwide economic debt crisis. It was in this context that Chile was seen as a good place to apply this development model.

The idea was well received by the military junta which had a longestablished shared political and economic agenda with the United States. The relationship between the United States and the military junta was key in the overthrow Salvador Allende's socialist government (Salazar \& Pinto, 1999). Since the colonial era, social and economic injustice was prevalent in this part of the world. As a result, new charismatic leaders (such as Allende, Fidel Castro, among others) could undermine the capitalist model and the United States imperialist interests in the continent (Escobar, 1998).

Consequently, and as a way to consolidate the relationship between the United States and Chile, neoliberalism was intended as a development model to firstly, boost the Chilean economy, and secondly to show that the neoliberal model could work throughout the world even in developing countries (Brohman, 1996). In order to do so, new and young Chilean economists were awarded postgraduate programmes and academic exchanges at the Chicago School of Economics to help implement neoliberal ideas in the country. Among these so-called "Chicago boys" was Sebastian Piñera, the current president of Chile who made his fortune during 
processes of massive privatisation of state companies, and also by the introduction of credit cards, something new in the country at that time (Salazar \& Pinto, 1999).

Details of the process of the implementation of neoliberalism are beyond the scope of this research. However, as Bauer (2005) has said, "the 1980 Constitution and its associated institutional arrangements are strongly weighted in favour of rightwing political interest, laissez-faire economics, and vested property rights' (p. 159). It is within this context that the main tool of water management was created in Chile. The Water Code was enacted in 1981 amidst a free-market approach, which some have called the Chilean model of water management (Bauer, 2005; Budds, 2009; Jenks, 2009).

\subsection{The tools of free-market managing nature: The Chilean Water Code}

Of the Latin American countries, Chile made some of the deepest neoliberal reforms with regards to the environment and resources (Liverman \& Vilas, 2006). New strategies of governance under a neoliberal regime sought to boost the care and sustainable use of water resources linked to private properties (Galaz, 2004). Thus, water was converted into an economic good, in a move towards promoting more efficient management of this resource (Bakker, 2005).

The Chilean Water Code declares that water resources are inalienably public property, and the national government may grant water rights to private parties where these are available (Bauer, 2009). This contradictory declaration means that when water sources are physically and legally available new water rights will be conceded. The applicant for water rights is charged a minimum amount of money from government. But, once the water rights are in private hands, water is declared as a good 'to be freely tradable, bought, sold, mortgaged, inherited, and transferred like any other real estate' (Bauer, 2005, p. 150). Yet, no taxes or fees for the government are imposed, unless users are not using those 
water rights. Nevertheless, this "free fee of use" was changed in the Water Code in recent years (Jenks, 2009). Finally, once water rights are granted they are protected by private civil law in the general system of real estate title registrations and are guaranteed under the Constitution (Bauer, 2005). Therefore, while water is public property in law, underneath it is clear that a private regime is the dominant aim of this document.

The Water Code is a law that reinforces the private property regimes declared in the Constitution and weakens government authority in conflict resolutions (Bauer, 2005). The government agency that determines and grants water rights is the DGA or General Directory of Water (DGA or Dirección General de Aguas in its Spanish acronym). This agency is located within the Ministry of Public Works, and operates according to the Water Code. One of the main conflict is when in a river basin appears multiple water users. Margarita Letelier, president of Nuble River Vigilance Committee has no doubt that whoever owns water rights has the legal power to actually decide what is done with that water:

There is no secret about it. We are the owners of the water of the river, so we have the raw material, thus we have the power to manage the business. We define where, when, and at what time we share the water, for instance with the hydropower companies to generate electricity .

(Letelier, interview,13.04.12)

Margarita Letelier is right, unfortunately. One of the main issues with the Water Code is that it actually says little about other water users who do not have water rights. The only distinction in water rights is between consumptive and nonconsumptive rights. Non-consumptive rights were introduced into the Water Code as a means to encourage hydroelectric development on rivers that already had their consumptive rights allocated (Bauer, 1998). These rights allow users to remove water from a body of water, use the water (ostensibly for hydroelectric generation), and return the water, unaltered, to the watercourse. Consumptive rights (municipal, industrial and irrigation), on the other hand, allow the user to remove water from a body of water and use it however they like, with no 
requirement to return it to the flow. Notably, consumptive and non-consumptive rights are the only two types of water rights outlined by the Water Code.

One of the major players among non-consumptive water rights are hydropower companies. For hydroelectric projects these water rights allow water to be used upstream as long as it is restored downstream, even though this practice affects water users downstream. The impacts and conflicts of this legal clause can also be seen in the Nuble River, a case in which the limitations of the Water Code to solve conflicts between different interests is crystallised.

Undoubtedly the Water Code has achieved what it was created for. Nevertheless, scholars have questioned the goals behind the Water Code, as well as its uneven consequences (Budds, 2004, 2009). Wealthy families (such as most of the members of Nuble River Vigilance Committee) and big companies have been able to buy more water rights than other sectors of the population, creating inequalities in the access to water. As a result, rural communities have seen their development limited, and poverty levels have increased (Liverman \& Vilas, 2006). This inequality has recently increased due to high levels of water rights in the hands of mining and energy companies, most of them owned by foreign investors. Among the privileged is ENDESA-Chile, a Spanish power company that controls $81 \%$ of the total water rights allocated for non-consumptive use in Chile, mainly for hydroelectric purposes (Gentes, 2008). This fact has fuelled strong criticism, from environmental and social perspectives. It led to the revision of the Water Code and modifications in 2005. However, the changes made were superficial and the basic principles and procedures of the original version, as well as its main detrimental impacts, have remained (Gentes, 2008).

Therefore, the Water Code considers water a commodity, separated from land and created water rights for all flowing surface water and groundwater resources. If water is available it can be granted in perpetuity almost for free (documents and signature fee apply), and once in private hands it can be purchased at market prices, with the general directory of water (DGA) playing an administrative role (Budds, 2009). 


\subsection{Chilean Water Code: Neoliberalising nature}

One of the central underpinnings of neoliberal ideology is the selfregulating market (McCarthy \& Prudham, 2004). The idea is that the market is the best and most efficient mechanism to administer goods and services. In order to achieve this, there must be increasing commodification so that goods and services can come under the control of market mechanisms (McCarthy \& Prudham, 2004). Therefore, Heynen and Robbins (2005) suggest there are four broad relations involved in the neoliberalisation of nature - governance, enclosure, privatisation and valuation. These features are quite clear in the Chilean Water Code, and will be used to explore in this section how neoliberalism has articulated water management.

\subsubsection{Water governance}

Water rights are issued by the DGA which must issue rights upon request if water is available and unclaimed. The state has little or no direct role in the Chilean water market, whereas the courts play an important role in dispute resolution. In fact, it is the inability of the courts, the DGA, and the Rivers Vigilance Committees to effectively and fairly mediate disputes that leads to some of the most problematic issues in the water market (Bauer, 2005; Galaz, 2004).

Water in Chile is often 'considered an agricultural input that must be harnessed and exploited before it is "wasted" into the ocean" (Budds, 2004, p. 331). In fact, this is one of the major and well-known arguments to justify the construction of dams along the country. During my interviews with government officials and other actors supporting the dam in the Nuble River, this was a recurrent and almost self-explanatory argument. It was articulated by those working in government agencies, irrigators in interviews, and even MPs cited in newspapers (LaDiscusion, 2012; RedBiobio, 2012; TerraChile, 2012). For instance, Jaime Yañez, a National Irrigation Commission (Comisión Nacional de Riego) official, stated: 
84, $86 \%$ of water reaches the sea without any instrumental value...large water flows run through the basins without any economic uses for agricultural or other sectors. Therefore, we decided to run this dams programme as a way to solve this issue.

(Yañez, interview, 28.04.12)

Without considering the environmental or social services that rivers provide in a number of ways, water flowing freely is problematic for Jaime Yañez. It is the waste of a valuable resource, a resource that is not being "rationally" or "effectively" used according to him. This represents an opportunity and even a kind of moral imperative to do something "useful" or productive with this resource. In a similar vein, Margarita Letelier, leader of the Nuble River Vigilance Committee suggested that combined irrigation and hydropower provide a rational, logical alternative to stop such waste, which she articulates as a kind of national duty:

Chile is a country with many rivers and with a very steep slope thanks to the Andes Mountains. Hence, Chile can combine irrigation systems with hydropower... and this is renewable and is a resource that is being wasted year after year, because we lose around 2,000 million cubic meters in the sea, $85 \%$ of the water from rivers is lost to the sea!

(Letelier, interview,13.04.12)

As we can see, in Chile granting water rights and managing this system has involved changes in governance as Heynen and Robbins (2005) have suggested. Changes have been made in institutions and legislation in order to allow the market to gain more prominence in the management and allocation of water as a natural resource.

The foundation of Chile's water management regime is that, by stepping out of the water market, the state allows the market to freely allocate water rights to the sectors of the economy that can make the most efficient use of them (Domper, 2009). In this way, it is suggested that water rights are allocated in an economically and, by extension, theoretically socially optimal manner. Thus, the role of the state is to create the governance structure - the Water Code - and make the initial allocation that allows the market to work by giving a price or 
economic value to water, or as Heynen and Robins (2005) have called it, to allow a process of valuation of natural resources.

\subsubsection{Water enclosure and privatisation}

The Water Code defines water as a national good for public use but water rights are unquestionably private property. These rights, once issued, are permanent, absolute, and are not tied to land titles (Bauer, 2004; Domper, 2009). Expropriation for bad use of water rights can only occur with explicit legislation and the state must pay market value for the rights. Furthermore, although the state - after the 2005 reforms - has the right to tax unused water rights, non-use of rights is not sufficient grounds to expropriate rights.

If there are multiple requests for the same water, the DGA is required to hold an auction. This has led to claims that the state does not prioritize one user above another, but rather the water to be put towards the most effective use as determined by the market (Domper, 2009). Others have criticized this stance (Bauer, 2009; Budds, 2004; Galaz, 2004), claiming that the Code is not as fair as it appears because it excludes poor communities and prevents them to having access to buy water rights, even of waters on which they have been dependant for years. Indeed, the structure of the Water Code implicitly values certain uses above others.

These processes mean that water is being both enclosed and privatized, two of the main elements that Heynen and Robbins have identified in the neoliberalisation of nature. They have defined enclosure as the capture of common resources and exclusion of the communities to which they are linked', and privatization as 'where natural resources long held in trust by regional, state, and municipal authorities, are turned over the firms and individuals' (Heynen \& Robbins, 2005, p. 6). As we can see, under the Chilean Water Code water is being separated from the communities previously connected to it, and transferred to private, mostly corporate hands, such irrigators and hydropower companies. 


\subsubsection{Water valuation}

Since the Water Code only recognizes consumptive and non-consumptive rights, the Chilean water market fails to consider other uses, services and values of water. So the process by which price is given to water can be seen to be assigning arbitrary values to nature. This is contradictory to some core ideas of neoliberal society based in the control of land (and water in Chile) "by those who work on it' (McCarthy \& Prudham, 2004, p. 277).

The efficiency of water use under the current structure of the Water Code is debated. The 2005 reform introduced taxes on unused water rights to prevent speculation by creating a cost for those who hold unused water rights, thereby encouraging optimal allocation (Bauer, 2005). Once again, the solution was the commodification and financial incentivisation of water. Such an approach neglects other (new or old) ways of using water. For instance indigenous management practices see water as a spiritual element, and many local communities include rivers as part of local cultural values (Berkes, 1999; Berkes, Colding, \& Folke, 2000).

Whether or not the Water Code protects and allows a more sustainable use of this natural resource has been a hard question for environmentalists and communities facing issues of water access and control. However, more recently in Chile another instance where water allocation can be appealed was established though. The environmental institution now plays a key role in projects using water and other natural resources. In the next section, I will explore how these institutions operate, describing the main features and ideology within which they were enacted. 


\subsection{The role of environmental institutions}

\subsubsection{Chile's environmental institutions: A history of (in)convenience}

Central to Chile's environmental governance is the Ley de Bases Generales del Medio Ambiente or NEFL (National Environmental Framework Law, hereafter NEFL) and the requirement for all projects (such as the dam on the Nuble River) to have an environmental impact assessment to be undertaken. A notable difference with the Water Code is that the NEFL was created under democratic rule, after the end of Pinochet's dictatorship. Despite the return of democracy, and some changes to the development model of the country, the neoliberal form inherited from the dictatorship was not changed. In fact, some have argued that neoliberalism was actually deepened and strengthened in Chile after Pinochet (Salazar \& Pinto, 1999). With regards to the environment, it was external pressures that led the first democratic government to include the NEFL in its political and technical agenda (Tecklin, et al., 2011).

In order for Chile to join the North American Free Trade Agreement (NAFTA), the Chilean government of Patricio Aylwin (1990-1994) had to enact an environmental law, as a pre-condition imposed by the US congress. The law was passed rapidly through the Chilean congress and in 1994 the Ley de Bases Generales del Medio Ambiente or NEFL came into effects (Silva, 1996; Tecklin, et al., 2011). Thus, as Sepulveda and Villaroel (2012) explain, 'the nascent environmental framework....was conceived and designed by economic and political elites during a democratic transition characterised not only by a commitment to the neoliberal agenda-which prioritised an economic growth that deepened and expanded the exploitation of natural resources-but also by a weakened civil society' (pp. 184-185).

These conditions were also central to the implementation of the NEFL,

which took place at a time when the relationship between the new democratic government and former members of the military junta was still weak and cold. The military still held important power and put pressure on the new government. Thus, 
the relationship between former members of the military junta that were still active in the army and the new elected government was marked by a strong political agenda in the consolidation of the new period of democracy. During this period (known as the transition), any important social and economic change to the model was agreed by both parties. Moreover, an environmental framework for the country was not a priority compared with other issues.

The speed of establishing an environmental framework due to interest in signing a trade agreement with the US, led to rushed legislative reform more concerned with creating an organisational structure than with a solid and coherent environmental focus (Sepúlveda \& Rojas, 2010). Thus, the Chilean government approached environmental matters from a position closer to bureaucratic and business interests than the aspiration to develop full environmental legislation (Silva, 1996). As a consequence, the NEFL established the National Environmental Commission (CONAMA or Comision Nacional del Medio Ambiente in its Spanish acronym) as a new structure within the state. As a part of its functions, the Commission was responsible for the System of Environmental Impact Assessment (SEIA or Sistema de Evaluacion de Impacto Ambiental in its Spanish acronym), in which project proponents must submit their proposals to be assessed. Also, a council of 10 ministers was established for CONAMA as its governing body and charged with setting governmental policy and enacting regulations' at a national level (Tecklin, et al., 2011, p. 886). Meanwhile, CONAMA's regulatory and decision-making actions at project-level were established through COREMA or Regional Environmental Commissions (COREMA or Comision Regional del Medio Ambiente in its Spanish acronym). These regional branches are at the forefront of the environmental institutions in Chile, because their main function is to decide on SEIA applications and issue permits. One of the main criticisms of COREMA is their case by case approach (Rojas, Sabatini, \& Sepulveda, 2003). Instead of looking for a national standard of assessment, criteria have been used in ambiguous ways depending on each case. As a consequence, local environmental demands have increased with this weak legal framework, creating scenarios within the country 
that have been called 'internal environmental demand' (Sepulveda \& Villaroel, 2012, p. 185).

Later, during the presidency of Eduardo Frei (1994-2000) what is known as "the Frei doctrine" was established, in which he declared that "no project will be stopped for environmental considerations' (Rojas, et al., 2003, p. 23). This meant that the new environmental legislation should manage natural resources through projects that could help the country to reach the status of a developed country. In this context, international companies viewed Chile as a friendly free-market territory for investment using nature, with a weak legislation. Not surprisingly soon after, the first environmental conflicts in the country appeared. The Ralco dam in Alto Biobío in the mid-1990s was one of the most emblematic projects, as it not only involved intervening in a unique ecosystem but also affected the indigenous Pehuenche population living there (Latta, 2011). The project was fiercely opposed by local and international organisations on environmental, human rights advocacies and indigenous grounds. Finally, after many years of legal disputes in courts, the project was approved, establishing a precedent, and sending a clear signal to the market about future projects and investments throughout the country (Latta, 2011).

This weak environmental framework continues today, and although some organisational changes have been made, the fundamental structure and policies have not been reformed. As highlighted by Tecklin et al. (2012) 'even substantial organisational changes are more feasible than minor changes in the policy approach within Chile's neoliberal model' (p. 892). More recently, and because Chile joined the OECD, some reforms to the NEFL have been made. However, these have only been of an organisational structure showing that the system is highly variable, and continued on the political will in the decisionmaking. The inconsistencies of the NEFL reflected in the SEIA will be explored in the next section.

\subsubsection{Assessing nature: Conceived, reformed, commodified}

In terms of recent changes in the environmental regime in Chile, this subsection explores the basic rationality of the initial SEIA and recent changes. By 
doing so, the subsection will expose the extent to which these changes inform the current processes for assessing nature, especially when this involves water.

As mentioned earlier, the main tool for assessed interventions in nature and to prevent environmental degradation was the SEIA. This tool allowed consideration of environmental effects to be included in the design and implementation of projects and activities carried out in the country. Thus, the evaluation and certification of both public and private initiatives are assessed to ensure they comply with the relevant environmental requirements.

Before the legal reforms of 2009, proponents of a project submitted their proposals to be evaluated under the SEIA. COREMA then decided if a project was approved, rejected, or approved with technical conditions. According to Tecklin et al (2011), 90\% of assessed projects were approved between 1993-2009. Although COREMA was created as an autonomous and independent entity from central (national) Government, in practice this was hardly the case. Most of COREMA's members were appointed by the nation's president. Moreover, the head of each COREMA was the regional governor, a member fully trusted by the President and appointed by him/her. This fact fuelled many criticisms from civil society who questioned the democratic, independent nature of this agency and its processes (Castillo, 1998). Furthermore, on numerous occasions, such as in the renowned case of the Ralco dam, the President directly intervened in projects that had been rejected by COREMA. In the case of Ralco dam, then president Frei not only lobbied with private investors, but also disaccredited, and removed officials from their position if they were not in favour of the project (Namuncura, 1999).

In addition, public participation in the process is limited. Opponents to projects can send formal comments to the national level of CONAMA, organisation to appeal decision made by COREMA who acts just at regional level. The period of public involvement was limited to the first 60 days of the process (MINSEGPRES, 1997). However, project proponents can modify or add information after this period of public participation was closed, implying a slow and bureaucratic procedure. As 
a consequence, local conflicts became more radical, and environmental institutions were contested and delegitimized (Ormazábal, 1997).

These criticisms of too much political intervention, lack of independence and limited public participation in the SEIA process, and new conditions that emerged as a part of the requirements to be part of OECD, led to reforms to NEFL in 2009. Under the reorganisation, new bodies were established. In synthesis, this process was reflected in the creation of the Ministry of Environment which replaced the former CONAMA. As figure 4.4 shows, alongside the Ministry of Environment, environmental courts, an environmental oversight agency, and an environmental assessment service (EAS) which replaced the former SEIA were established, which together would address the environmental management demands in the country. In particular, the SEA was created to manage the former SEIA as an allegedly more independent and more strictly technical agency. In addition, the COREMA's were replaced by regional environmental assessment committees, led by the regional head of the SEA and integrated by members of other public agencies related with nature (Sepúlveda \& Rojas, 2010). Nevertheless, the reform did not reduce political intervention, mainly because the approval or rejection of a project is based on the recommendation of competent agencies. In other words, the decision is made by government agencies appointed for political reasons. Hence, technical reasons for rejections can be reversed by political authorities, as previously occurred (Sepulveda \& Villaroel, 2012). In addition, public participation was only slightly reformulated. From the original 60-day period for responding to concerns, communities now have an additional 60-day period. Despite these changes, the case by case approach still remains in the system. Local environmental conflicts have continued to increase and the new process was criticised recently by OECD (Guioteca, 2012). 


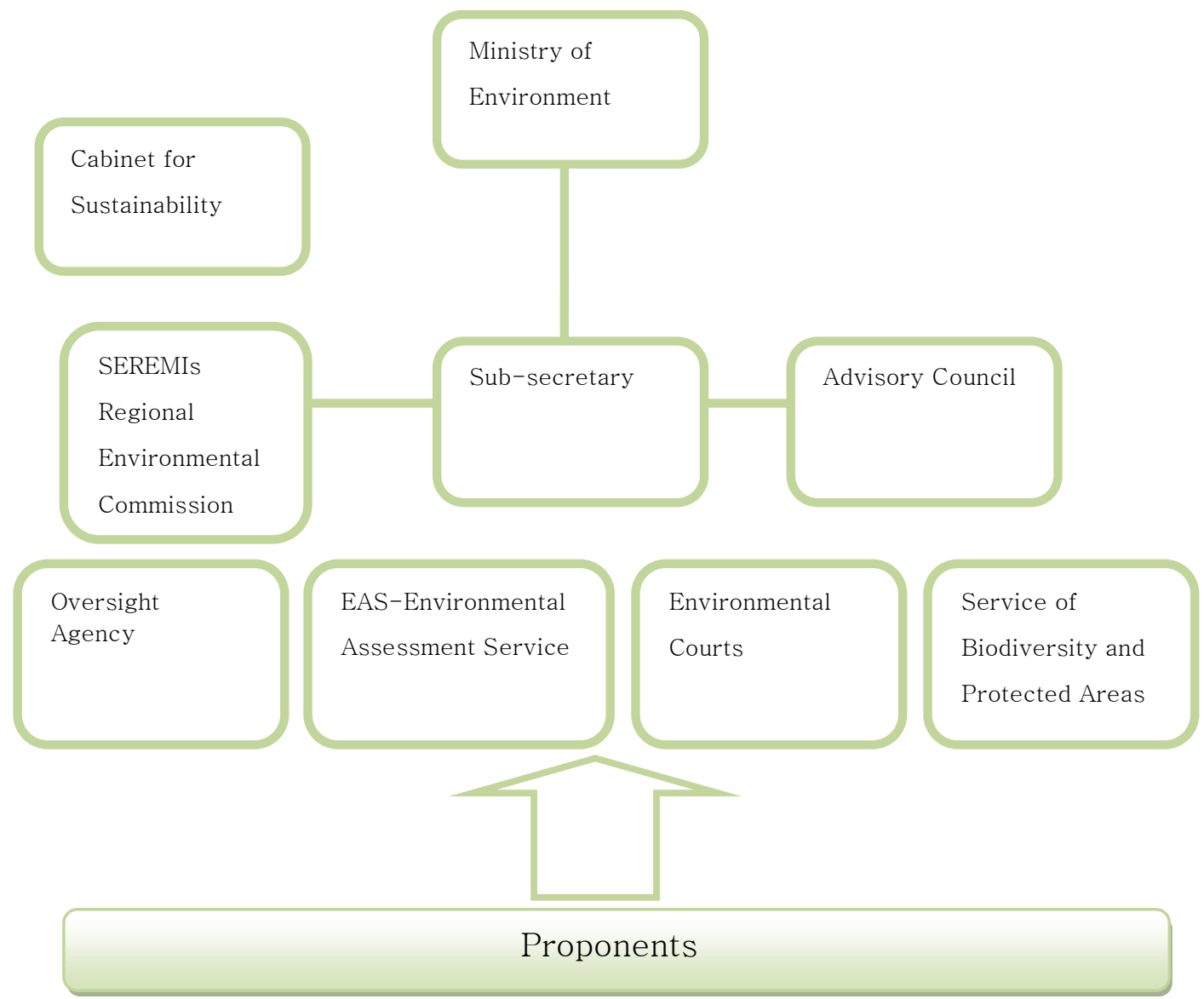

Figure 4.4 Organisational chart of Ministry of Environment

Source: Adapted from www.mma.gob.cl by C. Leaman-Constanzo

Finally, environmental courts have gradually been established in some regions, which suggests that the system was not prepared for all the changes required after three years of implementation (Guioteca, 2012). The idea behind the new environmental courts is to create an organisation autonomous from ordinary courts where most of the projects can be appealed. These tribunals will be organised in three multiregional jurisdictions, each comprised of two lawyers and one environmental expert who will be able to apply fines or other measures decided by the environmental oversight agency, based on the decisions taken by regional environmental committees (Sepulveda \& Villaroel, 2012).

In general, some of the drawbacks of the NEFL, and in particular of the SEA are in evidence in the case study of the Nuble River. 
Environmental institutions should have greater independence from the government in power....also, it should be an entity which includes the claims of the community properly...they should have more powers, because it is not enough assessing a project, and then delivering these projects to a private organisation to do and undo whatever they want ... then, who oversees compliance after that? Who monitors the projects if there is a change? Obviously environmental institutions should have more and more independence in decision making.

(Fernandez C., interview, 10.04.12)

While we have this inefficient environmental institutional system, a mini water project or a wind project, is trapped as well as the project in the $\tilde{N} u b l e$ River....Environmental institutions today, is an institution that is in its infancy...also, the environmental courts are still not being operational, so mean while they are not working it is a good intention but with no power to decide.

(Fernandez M., interview, 20.04.12)

The institutional environment is a joke here and everywhere. It does not work, and certainly it should have functionality because there are things that should not be allowed in our environment in this country.

(Letelier, interview, 13.04.12)

Research participants acknowledged that working with the current system limits possibilities to address environmental impacts in different ways. Overall, changes on the NEFL reflect failures and repetitions of the former system. First, despite claims of more technical and independent bodies involved in the management of nature, it remains highly politicised and subject to much political pressure from authorities at different levels. Second, public participation continues to be limited, and the voices of communities who raise concerns on projects are reduced to a very specific and limited period of time.

The issue of participation has always been regarded in the law, but it was not included as a strong counterpart, and that is a flaw of the system of environmental institutions.

(Cortez, interview, 03.04.12) 
One way to improve the NEFL would be that the roles of citizens in the environmental system were stronger and more integrated, but this does not happen today.

(Lopez, interview, 20.03.12)

Third, calls for more technocratic approaches that aim to facilitate the central role of the market in environmental management, have contradictorily led to an impressive increase in the size and complexity of the state apparatus. The fact that despite neoliberalism's claims to state reduction, it has tended to increase the role and size of the state in the context of environmental governance in Chile. Castree (2011) has suggested that a paradoxical situation is often presented, where the market is both created and regulated by the state, and so instead of stepping aside, the state is actively engaged in making the market work. Thus, the "minimal state" is more a myth than a reality with regards to the neoliberalisation of nature. The alleged 'neutrality' of states in relation to the market is also a myth. This is because states have to actively negotiate the interests of business, the public and other actors, including its own agenda, privileging certain actors or interests at the expense of others (Castree, 2011).

These facts are important, and are highlighted in the discussion of the Nuble River in subsequent chapters, as it reflects the limitations of the environmental management system. The continued political influences in the evaluation of projects, alongside the marginalisation of the public are very problematic issues. This political intervention has eroded the legitimacy of the environmental regime, suggesting again that the courts are the real last instance to stop or delay projects with high environmental impacts.

In cases such as the Nuble River, water rights are assessed by the DGA according to the Water Code. However, projects such as dams using water are assessed by the environmental assessment service (EAS). Both bodies and systems were conceived under the influence of economic drivers protected by a Constitution designed under neoliberal ideas, and have been subjected to reforms that have nevertheless reinforced their neoliberal nature. But both systems 
continue to operate independently from each other, posing challenges to secure an adequate framework for the management of water.

On the one hand, DGA and SEA are based on similar views of water as a resource. The Water Code sees water as a commodity, a strictly economic asset transacted by the market at market prices, while the SEA sees it as a resource to be economically used but subject to certain environmental regulations in a highly politicised and pro-market context. Thus, the neoliberal management of water, including the institutions, legislation and procedures involved in it, is today highly fragmented, complex, bureaucratic, partial and contradictory. Water management includes extensive involvement of the state to secure market-friendly management, and fails to address concerns regarding ecological, social, and cultural values. The way in which discourses from different stakeholders, including state officials, understand, make sense of and contest the tensions and contractions of the management of the Nuble River will be explored in more detail in the next chapter.

\subsection{Summary}

Overall, Chile has developed a neoliberal project that has profoundly transformed the relations with and uses of natural resources, which have entailed the enclosure, valuation and privatisation of natural elements and the creation and modification of institutions and regulations that despite their allegedly technical and neutral character, have strong ideological bias (Carruthers, 2001).

Clearly, dominant ways of understanding relationship between human and non-humans within Chilean society is illustrated by the neoliberalisation of nature. The case of Chile and its Water Code is a clear example of the application of a strong neoliberal policy agenda. Drawbacks are clear in the framework of water management developed in Chile (Budds, 2009). This has led to the degradation of the quality and quantity of freshwater resources around the country, and decisions over its use are increasingly creating tensions at different levels, especially in 
localised settings (Bauer, 2005). It is also leading to strains on livelihoods and social expectations of water users.

The contradictory, fragmented, and contested role of environmental institutions involved in decisions around the use of water are a key concern of this research, which requires considering the discourses of the stakeholders involved in the Nuble River. Narratives of participation and political intervention have been contested over time in Chile regarding the character of the environmental regime. These narratives will be explored in the next chapter, considering interviews of actors that debate the nature of environmental governance. Some suggest that the environmental management are more concerned with economic motivations rather than conservation and sustainable local development. By looking at these discourses I aim to explore the ways in which water can be seen a tool of development, one of the central questions of this thesis. In doing so, this research calls for re-thinking water management, seeking alternatives for a more comprehensive and sustainable approach of water use and management for future generations. 


\section{Chapter 5}

\section{Negotiating water: Nuble River stakeholders, conflicts and discourses}

\subsection{Introduction}

As the previous chapters have detailed, a neoliberal framework has shaped the way in which water and other natural resources are assessed and managed by the different Chilean governmental agencies. This political context has diverse effects when conflicts arise with regards to the access and control of water. Different stakeholders articulate a variety of discourses of their relationships with the Nuble River. It is important because it elucidates how these discourses are negotiated among different stakeholders involved, and how conflict arises. In doing so, this chapter will inquire into how these narratives are articulated and prioritised by each group, drawing on quotes from research participants.

While this chapter suggests that improvements in the neoliberal water management in Chile are not easy tasks, it also reinforces the idea that it is essential to incorporate the full range of discourses into decision-making, rather than privileging only economic rationalities.

\subsection{Farmers and irrigation: Markets, rights and lobby}

The major concern for the farmers of the central valley of the Biobío Region is the water shortage that the country has been suffering in recent decades. An inherently semi-arid region, identified by Amigo and Ramírez (1998) as a sub- 
humid Mediterranean bioclimatic region, it has been more recently affected by weather patterns such as El Niño, La Niña, and other atmospheric phenomenon associated with climate change. These phenomena are cyclical periods resulting in some regions receiving heavy rain and others prolonged periods of drought (Romero-Toledo, et al., 2009). The Pacific coast of South America, in particular Chile and the central valley of the Biobío region, are facing these weather phenomena that directly affect on irrigation requirements and therefore agricultural production.

With or without the occurrence of droughts, good water management is key to ensuring an adequate distribution of the available water resources, either surface or groundwater. The main economic driver for the farmers in the Biobío region is their crops oriented to both national and international markets. Therefore, the Nuble River basin is crucial to the northern part of the region due to the presence of rich soils appropriate for a variety of crops and animal farming. Berries, wheat, beet (for sugar production), dairy products, and rice are the central commodities of the region (Fleming, Abler, \& Goetz, 2010). For all of them, water is indispensable to maintain the level of production required to participate in competitive markets. Since the water rights were released through the Water Code, most farmers have been eager to acquire those rights to assure a secure source of water for their farms. When water rights were first introduced, the Nuble River basin was seen as a region with plenty of water. Later, when most of the consumptive rights from the river were assigned causing a over-allocation of rights, underground water turned into another valued source and started to suffer significant levels of stress in the whole area (Gazmuri-Schleyer, 1996).

However, the introduction of new irrigation systems into the agricultural sector in Chile since the beginning of the 1990's marked a milestone for farmers (Jenks, 2009). New ways to irrigate crops were presented as the solution to issues of water scarcity and maintaining productivity: firstly to increase the competitiveness of the sector in times when the Chilean economy dramatically opened to the world, and secondly for better use and distribution of the resource. 
Thus, new irrigation infrastructure was required to implement the new technology, which included new reservoirs, irrigation canals, drip irrigation, pivots, and so on.

It is in this context that a boom in the agricultural sector in Chile occurred, especially in the Biobío region. New international markets were opened to Chilean products through the introduction of large food companies that facilitated the agrofood chain business (Gwynne, 1999). In addition, these companies established links with farmers to be part of the chain of production (Fleming, et al., 2010). This means that incomes were boosted for the whole sector, from peasants to agricultural entrepreneurs. The term agro-food power was coined to describe a region that became a driving force in the agricultural sector of the Chilean economy. Then, the Biobío region became known as a agro-food power (Fleming, et al., 2010). The importance of supporting these high levels of production, and the significance of water management to do so, was addressed by Igor Borghero, Regional Irrigation Manager of INDAP (in its Spanish acronym) or Institute of Agricultural Development, an agency under the Ministry of Agriculture, when he said:

Well, our guidelines suggest a need to use water better, especially for peasant and smallholder agriculture. Then, the benefit of the construction of these great works, such as the dam on the Nuble River, undeniably brings benefits to them, but also to the whole region in general, to remain as an agricultural agro-food power.

(Borghero, interview, 22.03.12)

Farmers and farmer associations in the area also draw on discourses around the idea of agro-food power to advance their interests and position themselves in negotiations with other actors. For instance, Margarita Letelier, leader of the Nuble River Vigilance Committee, one of the most prominent farmer organisations in the area, said:

The nature of the agricultural sector in the Biobio comes through the production of apples, wine, table grapes, corn, beet for sugar to mention few. So we have the potential in this region to produce different crops per hectare, there are no other countries competing with us on this...so we have high expectations to further increase production, and companies are 
looking to those ones who make things the best... Therefore, we are able to be an agro-food power.

(Letelier, interview,13.04.12)

The concept of being an agro-food power has been a prevalent discourse amongst farmers to justify their struggles with and demands to the government. The notion is associated with generating employment, in particular for poor rural families, but most importantly, to emphasise the importance of water as a motor for their agricultural activity. Then, the concept is mobilised discursively to make demands for more infrastructure for irrigation such as artificial reservoirs and dams.

The Nuble River Vigilance Committee was established in 1956, being one of the oldest farmers' organizations in the country (RioNuble, n.d.) According to their website, this body is defined as a "private organization that brings together a large number of small, medium and large agricultural businesses of the Nuble Province and therefore represents the interests of a major economic force in the area' (RioNuble, n.d.). They also declare that their final aim is to commercialise their commodities into the market which have resulted that most of their members are wealthy farmers (Morales, interview, 12.03.12). Therefore, their members aim to have high-quality final goods, but most significantly, they want to protect the interests of the whole range of farmers within the area. Here again, is when water appears as essential and a pillar for their activities, as it is central to farming.

Although the organisation has a long history in the region, it has changed its focus since the introduction of the Water Code. Now it emphases its role in the protection and management of water rights of the Nuble River. In order for farmers to be members of the Vigilance Committee, they must have water rights to the river or the catchment of the river (in the case of groundwater). So here, water rights are privileged as the primary tool for water governance, and is considered by the central government as 'an attractive approach to water management' (Yañez, interview, 28.03.12). Rules and rights are imposed by the Vigilance Committee to ensure all members maintain infrastructure such as good upkeep on 
intake gates, maintaining a network of irrigation canals, assessing the flow of water in different areas of the river, just to mention few. All of this information is collected and given to technical staff who work full time exclusively for the Committee. As Margarita Letelier explained:

Studies conducted by our technical team show that the river does not have enough flow for our 5000 irrigators. Almost $80 \%$ of our members have water rights registered. The river has 109 million cubic meters, which is the maximum flow that we can use. However, in the growing season the river has in total 20 cubic metres which implies that the river is purely seasonal...the problem is that the river has a lot of water in winter when we do not need to water the crops, and it does not have water in summer when we need to irrigate a lot. That's why it's so important for us as irrigators to have a regulating reservoir (dam) to irrigate the basin that is approximately 118,000 hectares. If we had a regulating reservoir with 600 million m3 [the expected design of the dam], we could irrigate around 70,000 hectares in summer. Nowadays, we can irrigate only between 15,000 and 20,000 hectares.

(Letelier, interview, 13.04.12)

Furthermore, the technical team apart of maintaining hydrological studies of the river, also make updating the website, educational campaigns, organisational strengthens within the members, scheduling meetings, and preparing monthly reports to the directory of the Nuble River Vigilance Committee (Letelier, interview, 13.04.12).

This way of working with updated information has allowed the Vigilance Committee to push for more support in irrigation systems and infrastructure in the area. Moreover, the government through its rural development programmes and agencies have funded, and will fund even more irrigation projects in the area. As Marcelo Jelvez Sub-regional director INDAP mentioned:

Today, agriculture without irrigation is nothing... This year, we have seen that the water deficit has been prolonged, which tells us the importance of more irrigation projects to address these problems. Therefore, the benefits are even greater with the dam on the Nuble River as it will be a new source of water for peasants to irrigate their land and crops.

(Jelvez, interview, 21.03.12) 
Therefore, the construction of a dam as an irrigation reservoir on the Nuble River has been a real demand indicating in part at least, the way in which the neoliberal agenda has shaped their vision for the future. Technology (through building a dam) can provide them with water in order to maintain and increase production and compete in markets. Calls to build this dam have been on-going for around 80 years, according mentions in the media (El-Observatorio-Politico, 2011; Jimenez, 2012; TVU, 2011). Through successive governments, this request was not taken seriously until recently as a result of the alleged energy crisis in Chile. Due to this crisis, the Nuble River Vigilance Committee has intensified their lobbying with the Piñera's administration and ministries to realise this project. There is a particularly strong connection with the current right-wing government, as some members of the Vigilance Committee are part of the political parties in the coalition in power. Thus, the organisation and its members, through diverse mechanisms that include technology, social relations, authority, and legal rights have gained early access and control over the river (Langridge, Christian-Smith, \& Lohse, 2006).

However, the farmers fear power generation will be prioritised over irrigation, should the dam go ahead. The government has explicitly supported the project as part of a dam-agenda designed to address water shortages in agriculture (ChileRiego, n.d.; Sustentable, n.d.). Yet within this agenda the government also seeks to establish a series of multipurpose dams to cover both irrigation and power generation by hydro dams. As a consequence, the Nuble River Vigilance Committee has accentuated their campaign to argue for irrigation as the primary purpose of the dam rather than hydropower. The basis of their discourses is that they have the water rights on the river. In this context, irrigators see an opportunity in working with the power companies to establish a management model for the dam, as well as to make profits of it.

In light of these events, the Nuble River Vigilance Committee has engaged in a new strategy to support the Punilla dam by trying to persuade the general public of the importance of the dam (see figure 5.5). According to Chilean law, the state has to fund large irrigation works. The Vigilance Committee has seized on 
this fact in its awareness campaign. But because of the magnitude of this particular project, the government is looking for a strategic partner to help with the development. This is where power generation companies fit in the game; they have established large investments in hydropower generation throughout the country, taking charge of the social and economic mitigation that these projects have involved (Prieto \& Bauer, 2012). Further details of how these companies act will be further explained in the following section.

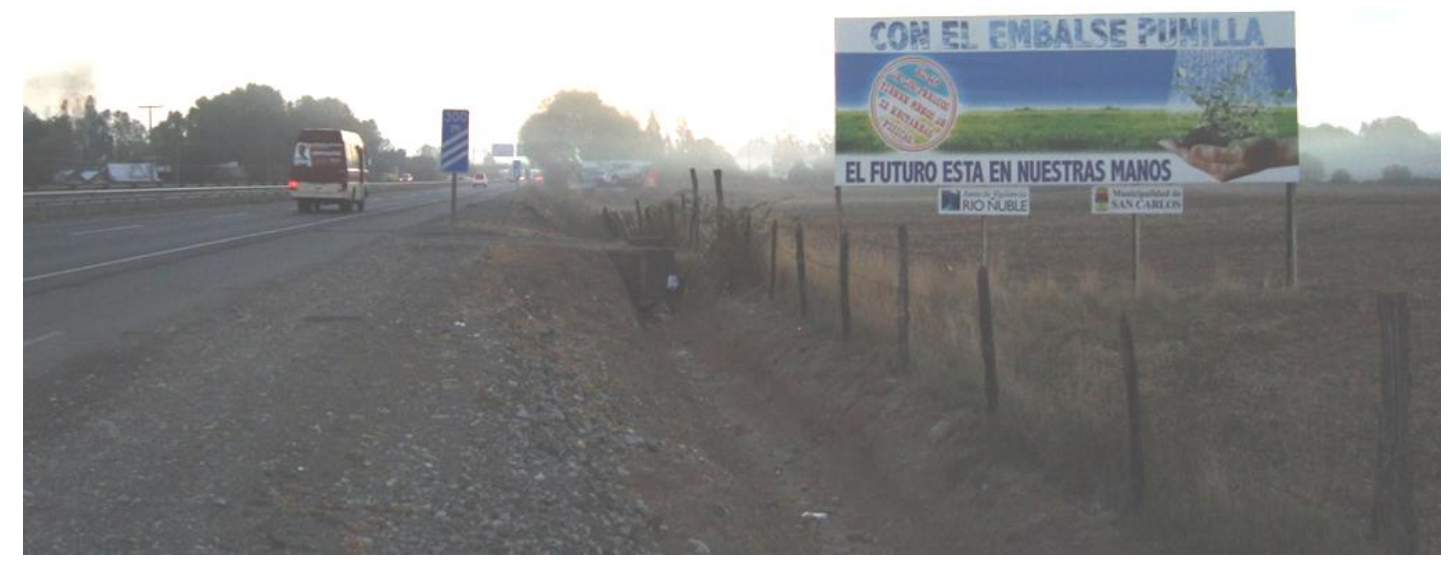

Figure 5.5 Sign in the main highway of the country for the dam project on the Nuble River. It reads: "With the Punilla dam, the future is in our hands. $60 \%$ of farms has less than 12 physical hectares". The sign is funded by the Nuble River Vigilance Committee and the local government of San Carlos, a prominent agricultural district in the central valley

Source: C. Leaman-Constanzo, 2012

In summary, farmers involved in the Nuble River basin are facing diverse issues and realities with regards to water management. The Nuble River Vigilance Committee plays a pivotal role on behalf of the farmers with water rights over the river. The committee brings them together as an organisation, is involved in governance, and as such has forged a way to manage the river while also bringing 
"development" to the area. Nevertheless, in Chile the pressure from hydroelectric generation companies over waterways is challenging this kind of organisation. It means that long term water access is not guaranteed even for farmers with water rights. Thus, within the neoliberal framework of water management in Chile, it is no surprise that trade agreements can take place among a few actors, regardless of other socio-ecological uses of waterways.

Therefore, the next section will explore how these agreements have been adopted and articulated by power companies using the Water Code. The section demonstrates that in many cases rural communities (such as those living nearby the Nuble River) are left behind in decision-making.

\subsection{Energy crisis, power companies and their effective "power"}

Chile is a country which has based its power generation on hydro power from rivers from the earliest days of the past century. The steep slopes between the Andes Mountains (a ranges that cross the country north-south and form the natural border with Argentina) and the Pacific coast makes the construction of dams and power plants for electricity generation on rivers suitable. The exploitation of this unique geographical feature of the country was boosted during times of economic prosperity in the 1960's in Chile, when large hydropower stations were developed in river basins (Bauer, 2009). The impacts to the environment were seen as necessary, affordable, and sustainable at that time. Also, these works brought development to rural communities, and even the creation of new human settlements in isolated and extreme areas of the country (Bauer, 2009).

It is useful to understand the context of hydropower generation in Chile in order to explain the development of this source of energy in the country. Also, this context helps to comprehend the role and discourses articulated by energy 
companies in the conflict over Nuble River. The so-called energy crisis has reshaped the energy agenda in recent decades, calling for alternatives and solutions.

The apparent crisis was triggered by some negative experiences, such as a natural gas scheme that sought to bring gas from Argentina through the Andes Mountains. An agreement between the two countries was established and Chile received gas supply from Argentina. However, the latest broke the deal by the year 2000, at a time when Argentina was facing both economic and political struggles, alongside internal gas shortage (Prieto \& Bauer, 2012). Companies together with the Argentinean State stopped the flow of gas to Chile in order to prioritise their domestic supply (Bauer, 2009). As a consequence, all the investments undertaken and proposed for this Chile-Argentina joint venture were lost, leaving Chile without another source of energy (Mares \& Martin, 2012). This scenario led to serious discussions around futures strategies of power generation for Chile. Having some suitable areas to develop renewable energies, especially in the sunny desert northern regions of Chile, as well as wind and tide power along the coastline, hydropower was still considered the most affordable option. Therefore, as Prieto and Bauer (2012) explain, 'the Chilean water institutional framework -the political, ideological, legal, and judicial- regarding water rights have determined that the original allocation of water pertains exclusively to productive uses, and within them, with special preference to hydropower' (p. 143).

For a country on the verge of being considered a developed country (Chile joined the OECD in 2010), renewable energy alternatives have not been prioritised, as the country is still to solve other urgent social problems (for example, current struggles over secondary and tertiary education systems). The cost of using renewable energy sources (does not include hydropower generation) is an obstacle that, so far, has prevented the government from incorporating new forms of power generation into the national power grid. This is why $r$

ivers are viewed as the solution, first due to the natural advantages of the country, and second because dams on rivers are highly economic providing a good 
return on investment for the country (Briscoe, Anguita, \& Peña, 1998). Also, the construction of dams with reservoir storage and run-of-the-river dams (ROR) are viewed as a sustainable and clean energy source by the country, a contested argument because of the known environmental effects of dams characterised by 'displacement of populations often the most impoverishes, and long-term ecological harm' (Dubash, 2004, p. 222). Even though, these arguments and discourses are internalised by different actors. For instance, María Ignacia Fernandez, Head of Communications and Community Management of a power company named CGE-ENERPLUS, said:

The run-of-the river dam is a clean and feasible alternative to generate cheap energy with low environmental impacts... There is no point of comparison with thermoelectric generation or even with a wind farm. They have greater environmental impacts, which can be 10 times that of a runof-the river dam project, especially in terms of the number of hectares used.

(Fernandez M., interview, 20.04.12)

In addition, Margarita Letelier, from the Nuble River Vigilance Committee also pointed out that:

Chile is a country with many rivers which can combine irrigation and hydropower generation without any problems ... hydropower is clean and renewable, and is a resource that is being lost every year in the country as we lose as much as 2,000 million cubic meters to the sea.

(Letelier, interview, 13.04.12)

Similarly, Bolívar Ruiz, SEA Regional Director of the Biobío Region also said:

We are a country with a narrow geography, so our rivers and streams have hydroelectric potential because they run down from the mountains with strong and great streams. This geographical feature is our advantage and we have to use it.

(Ruiz, interview, 03.04.12)

Based on these opinions, power companies have launched many small and medium sized projects of hydropower plants in rural areas, aiming to have 
minimum social and environmental impacts. Multidisciplinary teams are then allocated by power companies' projects in communities where dams or run-ofthe-river power generation projects are proposed to explore the main struggles or resistance that arises. María Ignacia Fernández from CGE-ENERPLUS, the power company interested to be involved in the construction of the dam on the Nuble River pointed out:

There is a commitment by the CGE group to the communities where our projects are developed, and therefore for us, it is not only about building a hydroelectric plant but also to enhance the places where we develop our projects. So for us, it is very important to establish fluid and permanent channels of communication with the community of San Fabian de Alico.... Communities or other stakeholders must understand that our company is not the state, but can be the richest neighbour in the area. That is true, however it does not mean that we will impose our rules there, not at all!... We come neither to replace what the Municipality nor what the State are doing, because our role is to make hydropower plants. But we assume that we will intervene in the environment, and therefore we are keen to meet the mitigation and compensation actions required by the legislation. That is why for our company it is extremely important to have relationships of trust with communities, and so we are settling a professional team there that lives with the locals to establish these relations.

(Fernandez M., interview, 20.04.12)

Certainly, this approach and discourse used by the power companies has brought positive results, in terms of obtaining better mitigation outcomes with local communities affected by projects in their territories. In addition, the Chilean state has seen this practice as a good way to deal with the impacts of those interventions in poor and isolated populations living around waterways. Thus, the Chilean state has positioned itself as a third party in negotiations. Yet, more importantly, the Chilean state has chosen to take on board power companies as big and powerful partners (Bauer, 2009), who can allegedly bring economic and social relief for those living in challenging areas. That is one of the main reasons why in many cases schemes of power station generation from dams, reservoirs, and run- 
of-the-river power generation are being considered as "multipurpose", such as in the case of the Nuble River case.

The financial input that large power companies bring is a strong factor in decision-making processes. According to Chilean law, the construction of a dam for irrigation purposes must be funded by the Chilean government, whereas hydroelectric dams are considered private investments (Prieto \& Bauer, 2012). Therefore, power companies help indirectly to fund irrigation projects the state should otherwise develop. Also, due to the fact that most consumptive water rights have already been allocated in Chile and groundwater rights have been granted mainly for irrigation, public-private joint ventures of river management are usually evaluated as positive. With them the Chilean state ensures the availability of irrigation water for farmers, while using the same dam for hydroelectric generation as well. This "two sides of the same coin" condition is beneficial for those involved in water management, especially to those with water rights. This was mentioned by different actors consulted in this research. Jaime Yañez from National Irrigation Commission said:

We aim to use water more efficiently. Today, all our studies are not just looking at only irrigation potential. The entire water infrastructure is being considered with a multipurpose character, which considers that other uses such as energy generation, mining, tourism, real estate, and all the benefits that a hydraulic engineering could bring. These two uses, irrigation and hydropower generation, could be very different and very competitive today. As a result, we are developing studies and we made agreements with the Ministry of Energy to encourage the use of all dams and all reservoirs for electricity purposes too.

(Yañez, interview, 28.04.12)

Also, Margarita Letelier, from the Nuble River Vigilance Committee, said:

We have a chance to work all together. We need irrigation but also energy. Then they go hand in hand, especially if you're going to make an enormous investment building a dam, the income resulting from that should have a double purpose. I think it is logical.

(Letelier, interview, 13.04.12)

Lastly, María Ignacia Fernández, of CGE-ENERPLUS, suggested: 
Water should be well used for both consumption and power generation, which is our theme. We have developed an agenda of projects with the government towards a sustainable use of water without spending or consuming it. Therefore, any initiatives for improving water management in the country are welcome by us.

(Fernandez M., interview, 20.04.12)

Based in these quotes, there is evidence that within those involved in the water market in Chile exist cooperation and mutual recognition of the importance of working together. However, there is little mention of other consequences of this sort of project. It is worth noting that the interviews for this research were undertaken before ownership of the dam on the Nuble River, how it will be managed and what the economic benefits of the project will bring are still to be determined. Many opinions may change as more specific details of the proposal emerge. Nevertheless, it does not change the dominance of the multipurpose discourse that prevails and shapes how rivers are identified in Chile this time.

As a consequence of the "energy crisis", power companies have established new forms of social relations with local communities in terms of compensation for affecting livelihoods. Economic and social incentives have been a driving force in minimising the negative image of power co mpanies using water in areas with rich biodiversity and unique local cultures. This is expressed already in the Nuble river conflict, especially in the town of San Fabián de Alico. Although the state has not yet negotiated with any power company to decide who is going to be involved in hydropower generation in the river, as noted, there is another run-of-the river project downstream developed by ENERPLUS, a subsidiary of the CGE Group. CGE-ENERPLUS already has a team working with the community in San Fabián. Their aim is to identify the main issues the community faces before the dam is built. So far, the local team has been involved in improving the main roads that connect the whole district, upgrading facilities for schools, delivering goods to neighbourhood organisations, building nurseries to cultivate native plants, and even providing courses to strengthen local leadership. As María Ignacia Fernandez explains: 
This is a consequence of the sustainability model we are developing.... the Nuble River project comes hand in hand with the CGE-ENERPLUS group that will be based in San Fabian de Alico for the next 50 to 60 years.. Also, this project includes social aspects that help to establish a long-standing relationship with the community of San Fabian de Alico... We (the company) came as residents to the district, perhaps the richer neighbours but neighbours at the end, so we have to live there as one more in the community. And due to that insertion, we understand that our project is an agent of change and development for the area, especially due to the impact that our work brings, so we take charge of these changes with both mitigation and compensation plans, which are now established by law. We seek not only to build an hydroelectric plant, but also to influence that community to live better, which is part of our social responsibility... therefore, this multidisciplinary team aims to keep this project not only as an engineering scheme, but also as a project that must be embedded socially in the community, because if we don't then the sustainability of the project over the next few years of operation will be very low, and the profits also can be bad.... This model of sustainability, which is being developed today, is the result of our past experiences in other hydropower schemes... Our environmental management and social insertion with the community aims to create a clear and bright future for our projects.

(Fernandez M., interview, 20.04.12)

Despite this positive picture of water governance and development involving different stakeholders and local communities, there are obstacles to its implementation. As María Ignacia Fernandez suggests:

The obstacle we have today in the SEA is enormous in terms of the small team of professionals working in that agency...and while we have this inefficient environmental framework any new project, be they a small solar project or a wind project, we will have obstacles, and this has happened with the Nuble River scheme. The environmental institution is an agency that is in its infancy today, it lacks tools such as the environmental courts. These are still not operational and have no resolution power...If projects are developed in a sustainable way today; it is because of initiatives of the companies, not because the environmental institutions enforce it.

(Fernandez M., interview, 20.04.12)

Therefore, this model of social development within and alongside hydropower projects is clearly highly desirable. Prioritising power input into the national power grid or respecting the law that protects those with water rights for 
irrigation are key issues that the Chilean state should solve. Otherwise, this model of business will not be attractive for power companies in the kind of neoliberal water market Chile has. With obstacles in the highly politicised and pro-market approach of environmental institutions, power companies continue to prefer projects where they manage river flow, and excluded the real participation of different stakeholders, so that effective means to address environmental concerns are jeopardised.

\subsection{Conservation and development: San Fabián de Alico communities and sustainable development}

Understandings of development in rural areas in Chile have been shaped at both regional and national levels. As in other parts of the world, planning programmes to achieve economic and social benefits for rural communities have centred their interventions within a national framework. However, rural communities have claimed that this vision is a mistake, and that local voices and narratives must be included in decision-making processes (Chambers, 1989).

Once again, these development discourses appear in the conflict of the Nuble River. In this context, locals of the town of San Fabián de Alico pointed out that there are other forms of development in the region that include tourism and recreation. The dam project will affect these forms of development potentially by excluding access. Moreover, these activities indicate an alternate relationship that locals have with the Nuble River basin.

Local practices associated with the river have been part of the life of many generations in San Fabián de Alico. Fishing, kayaking, and swimming are recognised as being the main activities related to the river. Moreover, there are other services provided by the Nuble River that are part of its socio-ecological importance (Loftus, 2009). The area is rich in biodiversity, and is highly valued by the local community. Community members emphasize the idea that conservation 
and development can be achieved through sustainable use of natural resources, and they continue to search for alternatives that embrace local experiences and knowledges. As Mauricio Morales, a local leader, explained:

The river has a huge value for maintaining the ecosystem here...the river has a number of birds, fish, animals and plants that use it, and they are the real owners the river. Therefore, we have to respect them and their natural habitats because we need them too....there are a number of creatures who have used the water for different uses.

(Morales, interview, 12.03.12)

This statement implies that the waterway's services have not been acknowledged by farmers downstream, and have been overlooked by environmental assessments applied at bureaucratic levels (Sultana, 2012). For instance, the river is a source of water for bees that, together with the presence of native forest in the area, provides high-quality honey with an exceptional and distinctive flavour (Fleming, et al., 2010). As a result, beekeepers in the area have a comparative advantage competing with others in the country. These different services and values associated with the Nuble River and its area of influence, have led community members to oppose the construction of the dam, which can be seen for instance in the signs many community members have put on their fences (see figure 5.6).
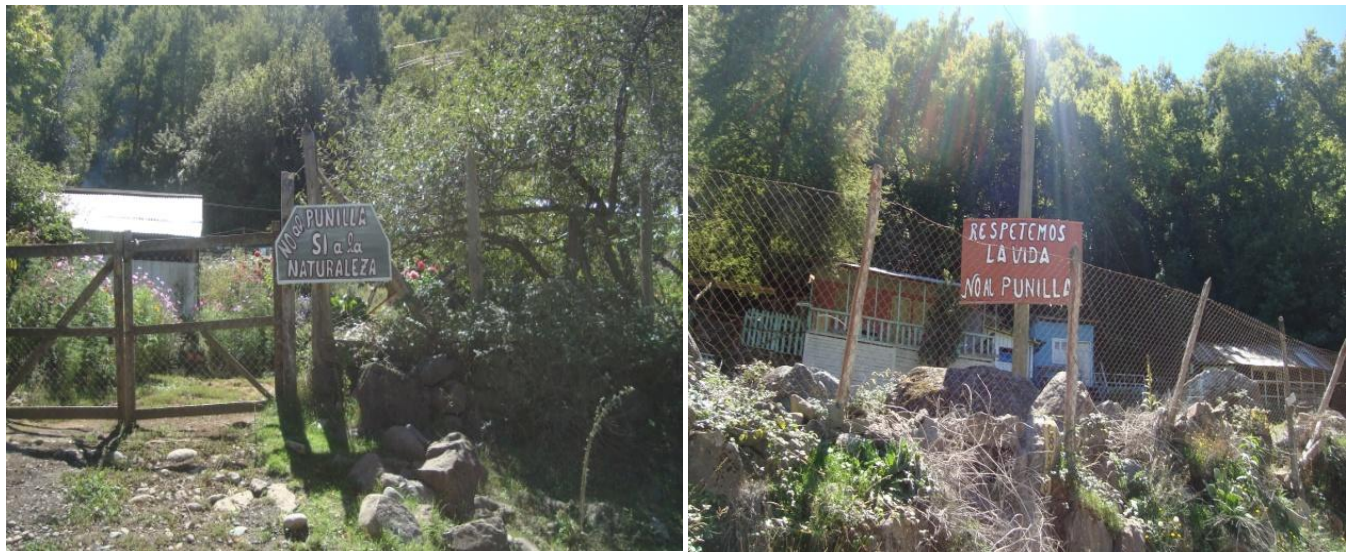

Figure 5.6 Local signs against the dam. They read "No to dam, yes to nature" (left) and "Respect Life. No to the dam" (right)

Source: C. Leaman-Constanzo, 2012 
In addition, the upper Nuble River is located in a mountainous area rich in biodiversity that has been recognised by the state as the Corredor Biológico Nevados de Chillan-Laguna del Laja (Biological Corridor Nevados de ChillanLaguna del Laja). Moreover, this area was recently declared by UNESCO as World Biosphere Reserve within its UNESCO's Man and the Biosphere (MAB) Programme (UNESCO, 2011).

The reserve aims to preserve biodiversity (nationally and globally), and was established in particular due to the region's rich wildlife and flora, including high genetic diversity (in particular insects) and the presence of huemules, an endangered deer species native of the Southern Andes mountain, endemic to Argentina and Chile (see Figure 5.7). The Huemul or South Andean Deer (Hippocamelus bisulcus) is literally an emblematic animal in Chile as it is featured in its national coat of arms. Also over time it has become an icon for conservation struggles by environmental advocates.
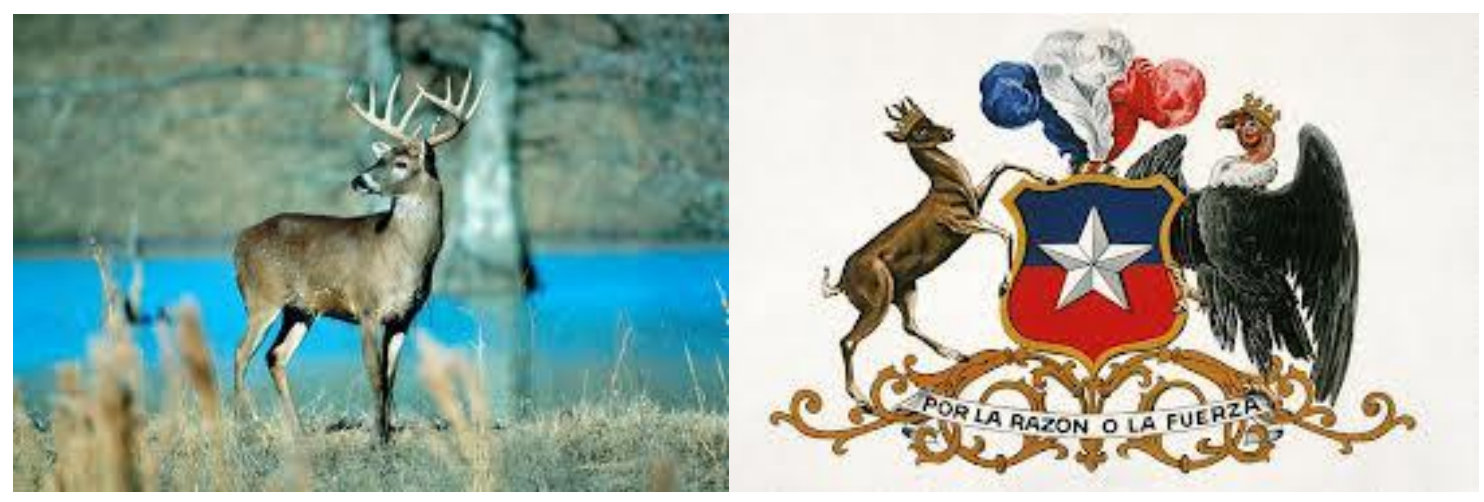

Figure 5.7 The huemul and its place in the Chilean national coat of arms Sources: $\quad$ http://www.dconstruccion.cl/?tag=huemules http://www.arabe.galeon.com/chile/pchile.htm

This is one of the most contradictory points of Punilla dam project. In 2004 efforts began to declare the area a Biological Corridor and World Biosphere Reserve. This included a huge range of government agencies coordinated by National Environmental Commission or CONAMA. For many years, this effort was shown as an exceptional model of a new approach to environmental governance and sustainable development. It included a participatory approach involving local 
communities and the local government, and was supported by the Biobío Regional Government and their regional planning programmes. However, in 2010 the same government body through COREMA approved the dam on the Nuble River, showing little coherence in the planning programmes for the area. As Bolívar Ruiz of SEA Biobío Region, stated:

After the approval of the dam on the Nuble River, the Biological Corridor was accepted by UNESCO as a World Biosphere Reserve, something we had been pursuing for seven years, but that was after the dam was approved. So, if we had known that before, for sure the dam project would have been evaluated much more strictly and would have had greater recommendations or comments [about conservation values].

(Ruiz, interview, 03.04.12)

Ruiz's comment raises several issues. First, it highlights the problematic dual role of the primary environmental agency in Chile, charged with evaluating and approving a project in an area it was at the same time aiming to protect. Also, it shows the shortcomings of the SEA. In a way, his comment suggests that the biosphere reserve once established served as external recognition that meant that it was finally taken notice of, but not before. With this thought the SEA fails to address and deal with the real impact of projects in areas of high environmental value. Moreover, it does not respect the will of local communities, local government and other actors who had already been consulted and supported the protection of their surroundings. And lastly, it demonstrates the contradictions and tensions embedded in discourses and plan to achieve sustainable development in the country.

Local tourism is among the sustainable development options already being developed in San Fabián de Alico. Tourism will be affected by the dam project. The natural advantage of the area for nature-based and sustainable tourism has been recognised beyond its communal borders. One of the most well-known examples is the Nuble-Fest, a rafting competition that has been running for the last 5 years. Every November thousands of competitors from around the country gather in San Fabián de Alico for one of the national championship events. According to the locals, the river has a better flow rate of water for the competition during that 
month (Fuentes, interview, 13.03.12). Over time this initiative has grown in terms of both competitors but also visitors, and has helped to raise the tourism profile of the area. Moreover, tourism highlights the dependant relationship that local people have with Nuble River, and its role in fostering more sustainable development options. As Juan Carlos Bustos, President of Committee of People Affected by the Dam on the Nuble River says:

The development of San Fabián de Alico is associated with tourism, but tourism with the river! One of the main economic activities of the sector is Nuble Fest...during those days a significant number of tourists arrive, and all the campsites are full. We offer horse riding trips, goat barbeques, tortillas [traditional Chilean unleavened bread], and so on.

(Bustos J., interview, 23.03.12)

This is also acknowledged by Enrique Concha, President of Los Sauces Neighbourhood Council (sector that will be flooded), who pointed out:

Now we do these things in the river such as the Nuble Fest, which opens the season. Many tourists come, even from other countries. So, we are expecting more people to come in the following years. Nuble Fest is done in the spring when the flow of the river water is perfect for rafting. Thanks to the river we exist here, so if they want to build a dam, our community and our life will disappear forever.

(Concha, interview, 13.03.12)

And this points back to the issue of the tensions and contradictions that exist between a local community and authorities looking approaches to development. On one hand, locals have defined their development through tourism using their surrounding natural resources, and on the other hand national and regional government propose a construction that directly affects and contradicts these locals' authorities. As Vladimir Fuentes President of Las Guardias Neighbourhood Council (another sector that will be flooded) express:

Our PLADECO (Development Communal Plan) indicates that the core of the development of this community is tourism. Why? Because we have plenty of natural resources, such as the river, the mountains, etc. Precisely what this dam project is going to destroy... What will we gain from the construction of the dam? Nothing, nothing.

(Fuentes, interview, 13.03.12) 
This contradiction is also made explicit by local leader Mauricio Morales:

Tourism is the key in this territory.... here the State has invested a lot of money training small entrepreneurs in tourism. Then the dam project comes and I wonder, why has the government trained all these people saying to them that this is the way to overcome poverty in a sustainable way? Today, after 10 years of support, highly trained local tourism initiatives are offering rafting and other services thanks to the river. The Nuble River is the main economic source of many families; they exploited the river in a sustainable and coherent way... so the management of the river should be in the hands of locals who use it in an ecologically sound way. But they cannot make decisions about the river because they do not have water rights. Now I ask, is that fair? They have lived their whole lives here!

(Morales, interview, 12.03.12)

But tourism has also been used more recently as a discourse to express opposition to the dam, and as a way of raising awareness of the social and environmental impacts of the project. This vocal opposition has included the Mayor of the local government and a Senator of the Chilean Congress who have engaged in campaigning for the protection of the Nuble River. In addition, the use of social media and networks, blogs, media, seminars, and others have been used to promote the effects of the dam if built. As a result, local and non-local residents are more informed than before of the consequences of the project for the river, as well as of the services the river provides for humans and non-humans. As Cristian Fernandez, mayor of San Fabián de Alico, points out:

This river is to me very beautiful, and that if we all do things right, there is an important niche for the development of our town and of future generations. We have been carrying out significant activities to support this, such as Nuble Fest that is currently hosting its fifth year.

(Fernandez C., interview, 10.04.12)

However, this campaign has not been without controversy, particularly due to its apparent lack of effectiveness. While the campaign against the dam has had 
high level see of involvement, it has mostly been only local, so at regional and national levels the conflict is not perceived as important. This has been attributed to the role of the local government in this process. In the early days of the conflict, the mayor of San Fabián de Alico was in favour of the project. He then changed his opinion as he became aware that he could lose votes in the municipal elections of November 2012. Local leaders are still aware of this change, and therefore were reluctant to include him in their initiatives against the dam, and are critical of his involvement. Pablo Zambrano Community Development Director for San Fabián de Alico Municipality for instance, said:

The reality is that the mayor and others from the local government have been involved in issues against the dam, but the truth is that they have handled it very weakly at municipal level.

(Zambrano, interview, 12.03.12)

Also, Rodrigo Lopez of NGO CODEFF or National Committee for the Protection of Flora and Fauna questions the fact that the local authorities lost an important opportunity to defend the interests of local communities formally. He says:

Municipalities play an important role, but they must be informed. Otherwise, failures are evident as happened in San Fabian de Alico. This council and the mayor supported the dam project at the beginning. Then they realized too late of their mistake... Municipalities' opinions have an important role within the EAS, which does not happen with other civil organisations or NGOs. They can negotiate better, but their involvement was weak and without any clear opinion.

(Lopez, interview, 20.03.12)

In addition, Vladimir Fuentes adds:

The Municipality manages very few things, and when important matters arise, they don't give them the appropriate relevance. For instance, the final report of the SEA has five volumes, but none of the members of the local council read it. Now, how do I know that? Because we went to a council meeting and the councillors and the Mayor knew less than us. Outrageous!

(Fuentes, interview, 13.03.12) 
It must be noted that in the recent municipal elections (November 2012), Cristian Fernández was not re-elected and will end his term in December. It is hard to make definitive conclusions, but it was clear while conducting interviews in San Fabián that the dissatisfaction of local people with his approach and actions in regards to the dam project was one of the reasons many people said they would not vote for him.

Another key impact of the construction of the dam is relocation. The social consequences of the relocation of around 40 families living in the area that will be flooded, is a highly controversial topic, and has been considered one of the worst impacts of this project. Narratives around displacement and relocation are emotional, and claims are that adequate compensation is impossible given how high the personal costs of moving are. Andres Muñoz, agronomist of the Local Development Programme of INDAP said:

From an economic and social viewpoint, there are people who have lived there all their life. Most of them probably do not have land titles, but they were born there, have raised their children there, and they live mainly from agriculture. The main activity in the area is raising goats, and doing so they manage to survive the entire year. So, what happens to these families? What is the cost of moving for these families? It's sad, eh?

(Muñoz, interview, 10.04.12)

Vladimir Fuentes also emphasised the cost of the huge change that relocating involves, not in economic terms but in terms of their attachment to place and their way of life:

This is going to change the way of life of people who are rooted to their land. Here we live in different ways from the cities. Trying to change the way of life of people who are in their 50s, 60s, and 70s or even are 90 years old. How do you think they will be able to cope with that?

(Fuentes, interview, 13.03.12)

But beyond issues of the compensation and adaptation processes involved in relocation, people also referred in their discourses to the "invisibility" and the disregard for other ways of life. Juan Bustos, one of the people that will be relocated if the Punilla dam is built, said this clearly: 
They [the government] think that up here there are only animals, trees, rocks, fish, water, etc...But there are people who live here too, people that are us and our families, and we are not being really taken into account seriously.

(Bustos J., interview, 23.03.12)

Narratives of other incommensurable costs involved in the dam project intersect with broader and deeper discussions around development and sustainability. As Pablo San Martin, Regional Head of the Unit of Land Information Management of the Biobio Regional Government said:

From that point of view there are obviously people who do not want to change their way of life, or perhaps are willing to change but not so radically, especially people involved in lifestyles such as herding. The costs we have to assume for an intervention such as this one in terms of development and environment definitely cannot be compensated adequately for the families living alongside the Nuble River that will be relocated. Therefore, this project is supporting economic concentration and benefit in the hands of only a few, but using the name and the flag of being a "sustainable development". Indeed, this is what happens with this dam project.

(San Martin, interview, 05.04.12)

How can other ways of living and relating to place and nature be accounted and fostered within a neoliberal, technocratic and contested framework? This also affects issues related to local identity and the urban-rural frontier, which bring the debate into an equitable development and sustainability within different social groups in a country.

\subsection{Summary}

As it was explained in this chapter, the capital and social relations of farmers located in the central valley, and their water rights on the river are a central part in the conflict. The Nuble River Vigilance Committee members are relatively wealthy and politically well connected which together with their rights over the river make their discourses in support of the construction of the dam 
strong. This also means that any agreement or decision in the management of the river must involve them. Therefore, they have apparently gained access and control over the flow of water of the river thanks to their better involvement in processes of social and economic capital (Gunderson, Carpenter, Folke, Olsson, \& Peterson, 2006).

However, the energy crisis of the country and the influence of power companies is also important here. Decision-making from the central government towards the multipurpose use of dams and reservoirs, mainly for irrigation and hydroelectric generation, have changed and complicated the landscape of freshwater management. The country's neoliberal legal framework for both water and electricity has facilitated the development of hydropower over other sources of energy. As a result, the current water governance is privileging small clusters of economic forces that seek profits from rivers, without considering other social and ecological uses for waterways.

These two strong economic players linked to river basins, farmers and power companies, are the main challenges for local communities living in and around them. The communities of San Fabián de Alico have pursued alternatives because of the dominance of these discourses. They have lived there with the river through many generations, but this clashes with a lack of other structural and relational mechanisms to maintain that accessibility (Langridge, et al., 2006). Also, having access to the river is potentially important as a form of resistance or subversion of neoliberal programme.

The campaigns against the dam project have been highly visible and influential at community level, but ineffective at regional or national scales. This is probably due to the fact that this area is impoverished, isolated, and far from the centres of economic power. But also, the high cost in terms of money and energy implied in putting forward a broader campaign against the dam would be usually assumed by charismatic leaders or city councils. However this has not happened in San Fabián de Alico, with consequences that are evident today. Therefore, any initiative from the local communities to voice their opposition to the dam needs to 
be supported by legal and scientific alternatives. However, even when doing so to a certain extent, the invisibility, irrelevance, and disregard of other ways of living (different from urban or involving big capital business) is evident, as are the dismissal of other, non-economic, non-technocratic ways of relating and connecting to the river based in tourism, recreation, and conservation.

Chile is a country with a high dependence on exporting natural resources that use freshwater for their production. Also, hydropower generation has experienced significant development thanks to the unique geography of the country and the regulation framework, which has led to increasing pressures over waterways and basins. In addition, the market approach of the Chilean water management system has increased the historical tensions between farmers and hydropower companies over water, especially as both are important economically profitable sectors. Altogether, these elements are complex. In the case of the Nuble River, the way in which the central government deals with these conflicts creating or failing to create partnerships with power companies such as CGEENERPLUS (and what those partnerships would involve), while also including medium and big farmers downstream, could become a referent for a different model of water governance in Chile.

However, the challenge would still remain as to how local communities that live and depend on rivers such as San Fabián de Alico could be involved. The narratives of relocation, economic mitigation and compensation, and other solutions proposed by the other stakeholders involved in the project (including the state), do not satisfy the local population at all and raise concerns about justice. They are not looking for better financial returns, but rather, while also wanting to improve their living standards, they aim to maintain their way of life, their families, and the connections and ecological services that Nuble River provides them with.

After analysing the narratives of these stakeholders in this chapter, the next chapter will now deal with one of the main questions of this research, which is how is water being understood as a tool for development. 


\section{Chapter 6}

\section{The contested use of water as a tool for development}

\subsection{Introduction}

In the previous chapter, I analysed in detail the struggles over the meaning and values associated with the Nuble River for stakeholders involved in the conflict. This final discussion chapter, in turn, focuses on the more implicit results that river management has had within the Chilean model of development. As discussed in chapter four, the pressure to keep the pace of development has led the country to undermine its natural resources in the search for future prosperity, wellbeing and to adopt a technocratic approach to environmental management. With a currently fragile environmental management system that reflects the institutional arrangements that have paved the way for a particular way of understanding progress, Chile is facing a significant dilemma with regards to the governance of natural resources. In this chapter, I will first analyse the way in which this technocratic view of development has influenced water management. Then, I will focus on the effect a property rights regime of water management has for those with interests in using that water. Finally, drawing on the lessons of the Nuble River case, this research exposes the numerous drawbacks of current river governance for this river but also more generally for the country.

While it is extremely difficult to provide solutions to improve water management, this chapter attempts to show that governance and management of river basins based in neoliberal ideologies have not been good for all. This helps to demonstrate that the Chilean water market is neither successful in trading rights 
nor sustainable for those dependent on waterways. The encounter of neoliberalism and nature in Chile has brought social inequality and marginalization, as this chapter will demonstrate.

\subsection{Explaining the progress of Chile: Water used as a tool for development}

As this research revealed in previous chapters, the neoliberal model imposed by the military junta and followed by successive democratic governments, has dramatically shaped the Chilean model of development, including how the environment is understood and managed. In this regard, exploring the meanings of water as a tool for development will help to understand the narratives that produce knowledge around water.

On the one hand, the causes of current water crisis in the country go beyond the Water Code as the main tool of water management. In order to understand them, it is important to look carefully to the development model implanted in Chile, which remains the hegemonic way to allegedly bring about progress and overcome social and economic issues. This path relies extensively on the exploitation of natural resources and the invisible hand of the market (Craig \& Porter, 2006). No doubt, it has allowed extraordinary advances in the country's economic achievements. Chile has been identified as the most reliable country in Latin America in terms of good returns on investment, low levels of corruption, and credible democratic institutions. Moreover, it was ranked $44^{\text {th }}$ country in the last Human Development Index Report of the United Nations Development Programme (UNPD, 2011).

Chile has based its economy in extractive activities, mainly mining, fishing, forestry and agro-food production. These sectors have kept the pace of progress in the country for many decades. Mining has historically had a particularly large share in both Chile's GDP and in its exports. However, currently two-thirds of 
copper production is in hands of foreign investors, and the rest is produced by CODELCO, the state-owned company (Gregorio \& Labbé, 2011). Prior to the 1980s, mining was fully state owned. Since then however mining has progressively been privatized. Details of the associated social and environmental impacts of mining in the country can be found extensively in the literature (Amezaga, et al., 2011; Oyarzún \& Oyarzún, 2011; Urkidi, 2010). Not surprisingly, water is key in mining exploitation, and therefore most of the superficial and consumptive water rights around mining areas have been given to those companies working on copper exploitation (CEPAL, 2005). Copper mining occurs mainly in the northern regions of the country, in or around the Atacama Desert, the driest desert in the world. As a result, communities and cities living nearby waterways used by mining activities have suffered from both limited access to water, and the high pollution of these rivers. However, the mining industry is a high consumer of energy, and as this thesis has previously explained in chapter five, is supplied mainly by hydropower generation. Therefore, mining is one of the main drivers of hydropower dams being planned and built in the country, which affects many rivers in the wetter centralsouthern parts of the country (CEPAL, 2005). In chapter five, the discourse of multiple purpose river projects was identified. This discourse goes beyond just irrigation and hydropower generation but works to promote development in other sector too, such as mining. For example, Yáñez of the CNR notes:

Today we are developing joint studies with the Ministry of Energy to use all the reservoirs and dams in a complementary way. Thus, the country's major economic activities such as mining, agriculture, fishing, and so on do not running off on energy which implies to stop their activities.... So, the water issue we have looked beyond the irrigation, because we see progresses in other regions of the country with different productive vocations, as those associated with mining.

(Yáñez, interview, 28.03.12)

The concept of governmentality here provides a useful tool to explore the opinion expressed by Yáñez. This kind of narrative, highlights the nature of the political project that is institutionalised through these discourses (McKee, 2009). The intervention showed in this quote by one of the members of the Ministry of 
Public Works, reflects how water is articulated in discourses of development seeking to alter subjects behaviour and practices to get final results. It produces new knowledges that have direct effects on common people and simultaneously legitimizes projects (for instance, multipurpose dams) towards economic growth creating effects such as social marginalisation (Dean, 2010).

Furthermore, rivers are the main source of power generations in Chile. As has been previously explained, the geographical conditions of the country lead to the fact that rivers and power generation are intertwined. The development of this kind of energy has been facilitated by internal and external events. Institutional and legal arrangements such as the Water Code is one of the most important internal factors that have contributed to the growth of this sector (Bauer, 2005; Prieto \& Bauer, 2012). External factors include the lack of other energy sources in the country, together with an unsuccessful natural gas agreement pipeline scheme with Argentina. In addition, neighbouring natural gas rich countries such as Peru and Bolivia, are highly resistant to establishing economic agreements with Chile due to historic discussions on border issues.

Today water is undoubtedly the fuel of the economy in the country. In particular, water from river basins is being assessed in terms of power generation and any future projects must consider this point. So dams, reservoirs, and run-ofthe-river dams have been and seem to be an unquestionable path to delivering power into the national grid. Evidence from interviews supports this claim to a link between water and development. For instance, María Ignacia Fernandez of CGEENERPLUS pointed out:

We need this kind of project because energy is key for the country to back-up the main economic sectors. Without energy, we will not reach the level of progress that everyone was expected.

(M. Fernandez, 20.04.12)

Here questions are raised about what is driving the model of development and the whole idea of economic growth. Who is expects this progress? What level of progress is it that is deemed to be needed? These 
concerns and the quote of Fernandez questioning the government's desires that apparently is using the legal framework to give privilege to some and punishing the wishes of others (Li, 2007b).

A similar situation is presented with the agro-food sector. The agro-food chain is one of the main incomes of the Chilean economy and it is mainly an export-oriented approach. Agricultural products are going to global markets everyday at a steady rate, consuming high amounts of energy in production processes. Moreover, while this sector generates jobs in rural communities helping them to overcome a long history of marginalisation and degradation (Murray, 2002), it also works to disempower them. The agro-food sector offers seasonal jobs with poor labour and health conditions. Also, due to competitive economies of scale, small farmers have become unviable, and campesino life styles are disappearing while transnational food corporations are expanding. This neoliberal framework further marginalises and threatens the rural poor or at least small farmers.

What happens is that these companies along with the State the only thing that matters is to generate money for the country's incomes. They want to keep good numbers of growth over the $6 \%$ or $7 \%$, with a low rate of unemployment, high GDP, etc. But everything has a cost, and what is the cost? Destruction of small communities, the environment and change of life style for us. This is unacceptable.

(Bustos J., interview, 23.03.12)

The way in which government and its technical discourses influence and shape human conduct (Dean, 2010) is exposed here in this passage. Set of practices from the central government persuade some type of vocabularies which is used as instrument to justify intervention and decisions. Then, these practices are internalized by people creating a discourse difficult to oppose. Moreover, this point is emphasised in sections 4.4 .1 and 5.3 where it refers to rivers are only valued when they are harnessed rather flow out to sea.

However, it is important to highlight that not all practices and narratives of the state are accepted. Farmers in the Nuble River look at state intervention with 
suspicion. Talking about development, Margarita Letelier president of the Nuble River Vigilance Committee, referred to her preference for a more passive state, as for her development is about successful market engagement and efficiency:

I would die if the state became the main administrator of water. Everything that is administered by the state is harmed, is inefficient, is poorly managed. And do you know why this happens? Because all public officials earn the same money, whether they have a good or bad performance in their roles... Well, development for me means always going forward, improving, and becoming better, more efficient and maximising the results and income with the same resources... yes, that is development to me.

(Letelier, interview, 13.04.12)

Letelier suggests here that for her private property, competitiveness and efficiency are key to both managing water and development. Her understanding of development, like most big farmers in the area, is strongly linked with the neoliberal framework. This in turn informs their support for privatisation, commodification, and enclosure of natural elements such as water, which are seen as key elements not only to maintain their business, but to engage in narratives around their contribution to national development. Based on this and the rights they have under the Water Code, they see the rolling back of the state (Peck \& Tickell, 2002) as crucial for the state to become only a witness of the market swings, and where other possible pathways for using water for development seem to be unthinkable or irrelevant.

This appreciation of development is opposite to the narratives of people of San Fabián de Alico. Development for most rural communities is strongly linked with the natural environment in which they live. Those natural conditions provide goods and services that are highly valued by communities, supporting their economies, but also crucially their identity and traditions.

The development must be harmonious and not just an economic issue. It should include aspects of family, cultural, environmental, and religious. As a society, we have to incorporate all of these features into the economic model, otherwise just few would reach degree of development at the expense of the sacrifice of others.

(Fernandez C., interview, 10.04.12) 
As section 5.4 mentioned, preserving local economies and conservation as reasons to stop dams have been part of the national agenda since the conflicts over the construction of the Ralco dam in the Biobío River in the mid 1990's. This area has the largest concentration of Mapuche-Pehuenche indigenous people in the country. Their emblematic fight against the Chilean State's environmental institution which set begins of the contemporary environmental and conservation movements in the country. Indigenous land, sacred places and pristine nature were flooded after years of allegations in Courts and fierce lobbying (Namuncura, 1999). Here, national and international NGOs, and indigenous and environmental organisations were key to raise awareness of the negative effects of the Ralco dam beyond the local boundaries, but also to question the development model. These concerns are also being currently articulated by some in the Nuble River conflict, as Mauricio Morales, one of the most influential local leaders suggests:

In general, these things happen because there are two types of development competing. The one from the communities in the mountains and their history, and another that is coming from cities, moving and consuming resources. Then, from that point of view, there are two cultures clashing.

(Morales, 12.03.12)

In other words, Morales is revealing that the language used "has the capacity to make politics, to create signs and symbols that can shift powerbalances' (Hajer, 2005, p. 300). As consequences, these mechanisms of governmentality have normalized certain decisions and have created political conflict in particular places. Another important point is tourism as an instrument by which local communities have defended their lifestyle, surroundings and put forward narratives to reinforce the idea that other development options are possible. Some scholars (Berkes, 2004; Scheyvens, 2002; Sharpley, 2002; Timothy, 2002) have suggested that mixing tourism, development and conservation is possible, if the nuances of a particular place are carefully considered. The incorporation of tourism within strategies of rural development has been seen as a way to support those living in peripheral areas (Timothy, 2002), who are often viewed unimportant at the national level. Therefore, implementing and training 
locals to develop small scale tourism is a strategy to make them visible and promote poverty alleviation in a less exploitative way. As Dallen Timothy (2002) expresses, "community based tourism is a more sustainable form of development than conventional mass tourism because it allows host communities to break away from the hegemonic grasp of tour operators and the oligopoly of wealthy elites at the national level' (p. 150). In the case of the communities of San Fabián de Alico, these narratives were articulated as a way to recognize and defend the services that the Nuble River provides to them. In this vein, Juan Bustos clarify what the river means:

Then, the development of San Fabiann de Alico is associated with Nuble River and its tourism. We offer to the tourists campsites, traditional food, fishing, kayaking, riding horse, etc. In other words, that tourist enjoys their holidays doing what we do every day.

(Bustos J., interview, 23.03.12)

People of San Fabián de Alico wants to build a more integrated form of rural tourism that reflects and helps to defend the particularities of their place, ways of living, and their values in a holistic way (Cawley \& Gillmor, 2008).

Water is an economic engine in Chile that has received a boost with the implementation of the neoliberal legal framework (Bauer, 2005, 2009; Budds, 2004; Prieto \& Bauer, 2012). Water is a mainstay for many productive sectors such as mining and agriculture, both considered the basis of the Chilean economy. Chilean industry has developed and reached a standard of production recognised worldwide, especially by the quality and delivery commitments of the goods of these sectors (Brohman, 1996). This benchmark rests in weak and market-friendly environmental institutions, which have brought progress and well-being through the exploitation of natural resources (see chapter four). As a consequence, conservation programmes and strategies such as the declaration made by UNESCO of World Biosphere Reserve for the upper Nuble River have become highly dependent on the will of private organisations to preserve nature. However, these private organisations could lead into the commodification of those zones, making it difficult to trust in their will. 
Furthermore, the separation between watercourses and society, after more than 30 years of the neoliberalisation of nature in Chile is evident. Any project that disrupts waterways or streams will be presented under a discourse of a national benefit, be it for the generation of electricity and its implications for mining, or for agro-food production. Thus, local discourses are made invisible against appealing to national goals and narratives of development.

With this model of river management, water is seen as a tool for development. However, the dominant definition of development is associated with legal control of water rights which establish particular power relations. This dynamic of relationship in developmental projects 'have targeted marginal groups' (McKee, 2009, p. 480) which has resulted in social inequalities and marginalisation.

Chile needs water to develop some important economic sectors, so the challenge is to find good governance of rivers (or the flow of them). Furthermore, this research has found that governance associated with the water market is also highly politicised. Careful attention needs to be paid to water politics in Chile as a way to improve the institutional arrangements necessary for a more sustainable use of the water resource. The complex scenario of the dam on the Nuble River exemplifies the above. Also, the involvement of politics in this case study for/against the project shows that water 'is a political good' (Fisher, 2008, p. 30), and therefore water is part of the political agenda which needs to be accounted in the country (Galaz, 2004). This complex relationship between water and politics is a cause for concern towards improving the Water Code and acknowledging that water should not always be managed only according to narratives of national benefit and economic development. The involvement of politicians often responses for public recognition and a stepping stone to other levels of their political careers. Consequently, it is important to ensure that politicians have the knowledge and capabilities to decide regulations and institutional changes to overcome the current shortcomings in river governance in Chile.

Considering the previous discussions in chapter four, five, and discussed above, as well as the literature used in this thesis, there are implications for using 
water as a tool for development. It seems that how development is defined, and how water is imagined in development in the Nuble River case, establishes three main arguments which can be generalised to the national context in the country. Hence, in the following sections I will expose these three arguments that reflect the main lessons in this research.

\subsection{Water markets and rights based model is neither successful nor sustainable}

The Nuble River is highly important for the many services it provides. Those services are not just restricted to local boundaries, but rather they are intertwined in national levels where water has been deemed essential for the country and its development. Thanks to geographic conditions between the Chilean Andes Mountains and the valley in the central-south regions, most of the rivers and streams have been used by communities for long periods of time as mentioned in the story I gave in chapter one, where I was part of a participatory project to design a potable water system in a poor and isolated community on the coast of the Biobío Region (see section 1.1.1). With the introduction of the Water Code the link between communities and water was altered, shifting towards a regime of concessions and third parties (Yáñez \& Molina, 2011). These water rights, along with aiming to support the management of water, were explicitly introduced to boost the economic activity of the agricultural sector (Budds, 2009). Thus, a key aspect of the Water Code was to ensure that those with water rights could irrigate their crops throughout the year. However, and as will be discussed below, many took advantage of this situation and bought water rights for the purpose of both accumulating them for future trading and securing access to water (Torres \& García, 2009). In light of this, and the unevenness of allocation, it is uncertain that the Water Code has achieved its two primary aims - environmental sustainability and economic success (details in section 3.5 and 4.3).

Allocation is underpinned by neoliberal agendas and weak institutions that allow the market to allocate water rights. Two issues follow as a result. First, 
water is over-allocated resulting in unsustainable water take and users being unable to take their full allocation simply because of low flows. As noted by Rodrigo Lopez of NGO CODEFF and discussed in section 4.5 above, weak institutions that are not independent of political agendas push for the economic benefits of water, without due regard for environmental sustainability or a sound basis on which to make such decisions:

There is a mention of environmental flows in the Water Code, but the record of this is poor. No environmental resolutions have mentioned anything about environmental flows, so we do not know what is happening with the resource in the whole basin. So we have to improve this instrument with other perspectives than those that exist today because the Water Code has shown that it is not a sustainable way to manage the resource.

(Lopez, interview, 20/03/12)

Thus, the water rights model is not successful because is not environmentally sustainable, nor does it allow users to irrigate crops all year round in situations where water is over-allocated.

Second, those who are awaiting the allocation of water rights or unable to afford to purchase water rights are by necessity, continuing to take water. For example, Margarita Letelier of the Nuble River Vigilance Committee notes that if the Code were applied effectively, "half of the irrigators in all basins of Chile would be without water, because they do not have registered rights' (Letelier, interview, 13.04.12). Therefore, the system is not economically successful as water is not being traded among water rights users. Because water use is not controlled, in effect the Water Code has resulted in more people using water than before, as economic interests have added to those more traditional users. For example, transnational corporations have accumulated rights entire watersheds without care for the ecological (Torres \& García, 2009). This has led to the degradation of the quality and quantity of freshwater resources around the country. Again, the model favours the few, leaving impoverished areas without this vital element. Juan Bustos from the local committee against the dam emphasised this idea: 
We do not have money to buy water today, and probably we will not have money tomorrow when the dam exists. Then, the dam project benefits are few who do not know even how to manage that water.

(Bustos J., interview, 23.03.12)

The Chilean water market has been claimed to be a successful model by international organisations such as the IMF and World Bank (see section 4.2 and 4.3). Yet it is highly contested among sectors of the academy and grassroots organisation (Budds, 2004; Galaz, 2004; Liverman \& Vilas, 2006). They argue that it is linked to a clear neoliberal agenda that promotes environmental degradation to keep pace with the economies in other countries of the third world (Escobar, 1996).

In the competition for economic development and the race to "progress" as a nation state, economic sustainability has taken priority over social and environmental sustainability. Rather than the win-win scenario neoliberal proponents advocate via the notion of 'trickle-down', it is now well established that neoliberalisations produce win-loss scenarios and increase inequalities and environmental degradation (Larner, 2000; McCarthy \& Prudham, 2004; Peck \& Tickell, 2002).

\subsection{Current water management in Chile as it stands is not good for all}

The Chilean neoliberal state has apparently considered development through win-loss scenarios based on the export-growth model. Social and environmental effects have produced diverse results in the country (see section $5.2,5.3,5.3)$ that has produced knowledge of development in different ways for different groups.

The Nuble River case is no exception, particularly in the narratives of locals who will be affected by flooding a biodiversity rich area, and the relocation of 
families (see section 5.4 where the consequences of the dam were explored). In addition, non-economic perspectives and approaches of using watercourses are not considered under the Chilean Water Code. The dominance of economic growth and neoliberal technologies of governance mean that holistic understanding of the socio-hydrological cycle proposed by some scholars (Castree, 2005; Kaika, 2006; Loftus, 2009; Swyngedouw, 2004, 2009; Zimmerer, 2011) is still a long way off in Chile. Thinking through water management as a socio-hydrological cycle renders visible knowledge and relationships with water that remain invisible under the dominant neoliberal discourses. Current water management in Chile is physically and discursively shaping the future life of communities in uneven and complicated ways.

The demand for hydropower generation is significant, especially because it is needed for the mining, agricultural, forestry and fishing sectors as well (section 6.2). The loop between water, hydropower generation, national income and development remains a crucial one. In fact, the government of Chile recently released the first National Energy Strategy in 2012 (MINENERGIA, 2012). The Strategy is based around the notion that Chile is currently facing a challenge to have enough competitive energy resources to achieve the desired level of development in the next decades for the benefit of all Chileans (MINENERGIA, 2012). Ministries and other public services within the Chilean State are working along the same lines, as Jaime Yañez of CNR expresses:

We are promoting a strategy of water management that we are coordinating with five other ministries...Because where there are reservoirs, there is development. Water is strategically important for agriculture, as well as other economic sectors. For us where there are dams there is development because they generate agriculture, they provide energy, and even tourism thanks to the lake formed. Therefore, dams generate business, growth, and positive externalities for human settlements.

(Yañez, interview, 28.03.12) 
The last point is remarkable considering that the Chilean state is investigating, promoting, deliberating and making decisions on the Nuble River, and the effects of this approach have not been positives for all. For instance in the Nuble River case, the Chilean state does not want to implement the project on its own, and looks for a partner in the water market (mainly power companies) which implies a clear message to market and its property rights regime (Castree, 2011; Peck \& Tickell, 2002) which benefits those with social and economic power.

Given the embeddedness of neoliberalisation in Chilean governance, especially in relation to water, and the unevenness of its effects, it is crucial to highlight instances where it is contested and critiqued. As Karen Fisher (2009) argues 'contested discourses of neoliberalism and development have provided an opportunity for reconceptualising the role of the state and the emergence of new forms of governance' (p. 194). It is clear that the neoliberal discourses imposed by government (see section 6.2) have privileged a development model based on economic growth.

In particular, with the Nuble River case, the unevenness of these dominant narratives and that neoliberal strategies and discourses has produced win-loss scenarios are evident. This point seems to be key to the contribution that this research can make to re-think water management in Chile. In particular, it helps to highlight the need for a new form of water governance, so water resources can be assessed in more comprehensive ways to inform important decisions. Otherwise, mirrored by research participants that build narratives around a national development to justify projects such as the dam on the Nuble River, imposing an powerful discourse that affect local places and peoples, and reinforces the idea that water market is not good for all. 


\subsection{The encounter between neoliberalism and nature in Chile has increased social inequalities and marginalisation}

In the Nuble River, power companies and central government have declared that they are taking on board communities opinions to diminish the impacts of their interventions. However, most interventions are related to mitigation measures for those directly affected. Nelson Cortez, professional in charge of the evaluation of Nuble River dam project from the SEA explains that:

If you take another look at the same problem, we know the area is going to be flooded, but that project will take those families and relocate them somewhere else. So, if those people are happy with that, and with other social, economic and humanitarian compensation given, they would feel settled and happy again.

(Cortez, interview, 03.04.12)

Here there is a key question though. What if the compensation is inadequate to them? The bigger issues with this quote is that "progress" of this nature is renowned for its attitude that you can just go ahead and move people around and give them another bit of land, some cash and that will shut them up (Li, 2007b; McKee, 2009). It ignores any emotional attachment to land, to place, to the histories that those people have with the locality that is part of their very identity. Moreover, the effects of such developments are unequal, affecting poor communities rather than wealthy ones because wealthy communities will fight, and it will cost a lot more to relocate them. These narratives of injustice are a compelling call to care for those most vulnerable. Yet, hiding the injustice is a powerful rhetoric of progress, growth and development, alongside appeasement through compensation and relocation (rather than displacement) that masks the real effects of the project.

As I discussed in section 6.2, water when used as a tool for development combines a complex array of drivers that perpetuate marginalisation of those 
already marginalised (as Nuble River case) through water rights/access, relocation, lack of recognition of cultural-social-spiritual relations with the land and river, and livelihoods that depend of rivers outside agriculture and power generation. When water is valued for its development potential only, dominant power relations, driven by neoliberal rationalities shape what is legitimate knowledge and so what arguments are heard and incorporated into decisions made on water management.

One strategy to oppose the dam has been to seek international recognition of those areas as valuable and rich in biodiversity. Hence, using mechanisms that are also based on scientific and technocratic approaches, these actors bring issues of local conservation to an international arena, creating narratives that question the Chilean neoliberal economic model that privileges the exploitation of natural resources to support economic growth through the participation of global markets (Harvey, 2005). However, these actions have not always had the expected results. As was explained previously (Section 5.4), the declaration of World Biosphere Reserve by UNESCO in the upper area of the Nuble River has had little influence in the decisions made with regards to the construction of the dam. This could be seen as the outcome of the relationship between neoliberal modes of governmentality and activism (such as environmentalist and social justice movements), characterised by 'fissures, disjunctures, and confrontations of various kinds' (de la Cadena \& Starn, 2007, p. 21). Nevertheless, the dominance of neoliberal discourses managing nature mean that alternative arguments have not been heard, such as the declaration of the area as World Biosphere Reserve. Moreover, public servants have adopted these dominant narratives. For example, Ibor Borguero of Indap states:

The truth is that the area to be flooded has some touristic attractions and it has beautiful natural surroundings which gave the area this international recognition. However, there are other areas of the country where the surroundings are much more pristine and exceptional, such as the Patagonia region. If we compare these two areas that I mentioned [the upper Nuble River and Patagonia] there are notable differences. So if the decision were mine, I would rather keep one to the detriment of the other.

(Borguero, interview, 23/03/2012) 
Facing poverty and marginalisation, local communities such as San Fabián de Alico assert that the river gives them all they need to develop and overcome poverty. This does not mean wealth, but certainly minimum standards to reach an appropriate level of well-being. However, the discourse of equality and inclusivity towards managing the river articulated by central government lies in tension with ideologies of competitiveness and individualism proclaimed in the neoliberal model. Therefore, it is important to pay attention to those whose everyday life is connected with waterways (see section 5.4). There is a need to increase awareness in communities, like those in San Fabián de Alico and others (nationally and internationally) who are experiencing the impacts of these kinds of interventions, to demonstrate that there are uneven effects of considering water just as an economic value.

\subsection{Summary}

Trying to find out how water is understood as a tool for development in the Nuble River has revealed that particular issues in a particular place are the result of national and even global perceptions of a development model. Development can be thought of as 'a philosophy, a process, the outcome or product of that process, and a plan guiding the process towards desired objectives' (Sharpley, 2002, p. 23). So the "desired objectives" are evident, they are just no desired by everyone in the way in which rivers are managed in Chile. It seems that these desired objectives are privileging a few supported by institutional mechanisms and pursuing the commodification of commons (McCarthy \& Prudham, 2004). The Nuble River case study highlights the way in which neoliberalism asserts market led development through economic, social, and political goals (Scheyvens, 2002), and how all these aspects converge. However, some of these wider goals (social and political) are undermined through the destruction of a social and environmental area in the name of development. It is necessary to expose this fact, especially for 
those facing the dispossession of water (Fisher, 2009; Harvey, 2003; Swyngedouw, 2005), which is one of the main outcomes of the Chilean Water Code since it was enacted.

Understanding the neoliberalisation of nature in Chile after more than 30 years of its application illustrates that neoliberalism has been destabilised and is not an homogenous process. Rather, it responds to a distinctive context where the flow of its rivers is needed to develop some important economy sectors. The challenge remains to find better alternatives for water governance to avoid total market control, especially in a country in which the market is embedded in the deepest roots of its development model. Moreover, most of the literature on water politics and neoliberalism has focused on the effects of neoliberal reforms when the private sector has been part of the infrastructure of water supply. Notwithstanding, far less attention has been given to explore the process of commodification of water when it is considered an element of national relevance, especially in relation to issues of access and scarcity as in the case of the Nuble River.

Damming a river has enormous consequences for the socio-ecological character of a river. This is common knowledge mentioned by most of the participants of this research. However, damming is also a feasible solution to manage water shortage. This is particularly important as most people who hold water rights have not been delivered with the amount of water they had allocated to them in the area (Letelier, interview, 13.04.12) putting in evidence the lack of success even for those with water rights. Despite this, the dam proposal for the Nuble River has resulted from an extreme market approach based on the Water Code. This research suggests that the Water Code has failed to account for other aspects of water management such as social and environmental outcomes, and rather, it just sees water as a commodity that can be traded without considering cultural values or other services essential to the life of humans and non-humans.

Finally, I argue that the outcomes of the encounters of neoliberalism and nature have increased social inequality and marginalisation, showing that water 
conceived of as a tool for development is not always good for everyone. The omission of these issues in places often rich both in biodiversity and socio-cultural heritage, is a cause of concern for Chile and more globally. 


\section{Chapter 7}

\section{Reflections, findings, and suggestions on water management in Chile}

This chapter gives a brief summary of the research and conclusions from the thesis. It will explore what the findings suggest for water management in the future, by considering areas for further research, recommendations for policy and practice, and some limitations found in the research process. Finally, it offers some reflections on the overall significance of the project.

\subsection{Interpreting findings: Conclusions and implications from a case study}

This section addresses the principal question about the understanding of using water as a tool for development in Chile. To explain this, it is necessary first to answer the specific sub-questions posed for the case study introduced in Chapter One.

The first question asked how is neoliberalism articulated in the discourses employed by the stakeholders in the Nuble River, and how is the conflict negotiated? These questions focussed on an analysis of dominant discourses around access, rights, and control of water in the case study, but also in Chile more generally. The conflict on the Nuble River has led stakeholders to articulate their narratives towards recognition of their particular struggles linked to this case study. The conflict drew attention to differences in water uses and how this resource has become essential for the country. 
Powerful discourses were used by participants to expose how this conflict has been expressed under a neoliberal governance of natural resources. The narratives dealt with direct implications of the dam on communities, irrigation, conservation, and power generation. The implications are varied, showing that the proposed dam creates a scenario of winners and losers. Irrigators and power generators generate national level economic growth at the expense of local communities and biodiversity. So, why is this sort of solution is chosen? This question is key when looking for an answer in terms of the cost of progress. Under neoliberal discourses, the extraction of natural resources is legitimised in order to keep the pace of the economy. As a consequence, emotional attachments to places are not part of the agenda of policy-making as important matters, but they are for communities living and dependent of natural surroundings. While some scholars point out the importance of including different approaches on water management like the hydro-social cycle (see section 3.6 and 5.4), those voices are hidden in light of the technocratic view embedded in the neoliberal model which were expressed by stakeholders in this research.

The second question asked what are the social and environmental implications of the relationship between neoliberalism and nature in the case study? In addressing this question, the lens of political ecology helps to understand the conflict of water in Chile from a historical and multiscalar perspective. In addition, it allows insights into the consequences of the neoliberal model adopted in Chile and how it has affected water management in the country. The introduction of the Water Code triggered a series of outcomes both in society and in government institutions. As a result, increasing tensions of freshwater resources have set the political, social and environmental agenda. Looking at those consequences allowed me to acknowledge that strains on water users are beyond a local problem. It leads to the recognition that the conflict in the Nuble River deals not only with the dam and its effects within a particular community, but also it is a response to global and national arrangements that trouble the livelihoods of communities and their use and relationships with their natural surroundings. Drawing from the lessons of the Nuble River case, and the general consequences of neoliberal water governance in 
the country, the tensions of accessing and using of freshwater bodies will increase in Chile, causing inequalities and marginalisation in those most vulnerable.

Finally, the primary research question asked to how is water understood and managed as a tool for development in Chile by different stakeholders? The evidence suggests that water has been used as a technology that leads development. The use of water has been imposed as a national desire because of its perceived association with creating opportunities for development. It showed that while some changes in the Water Code have been done, the predominant discourse speaks of water as a commodity that rests in the market/rights model. This has increased struggles over waterways without considering other cultural, environmental, and social services that they provide. Hence, water would bring development through an exercise of power, constraining the self-determination of human beings for its use (Foucault, 1978).

The Chilean state is influenced by neoliberal thinking that has become embedded as dominant discourses which have shaped and disciplined subjects (Peck \& Tickell, 2002). In this regard, water was targeted as a cornerstone in the economy for its multiple uses mainly for the agricultural, mining and energy sectors. In line with the neoliberal approach adopted at state level, the Water Code was enacted as a series of practices applying the neoliberalisation of nature (details in sections 4.3 and 4.4). However, as has been demonstrated, this tool is neither successful nor sustainable (see section 6.4). Over-allocation of rights, insufficient knowledge of sustainable flows, and speculation of rights to mention few, have plagued the Code's application producing serious interventions in nature changing enormously the socio-ecological character of rivers.

I argue that this scenario of using the water as tool for development in Chile which is based on the neoliberal ideology of the Water Code, suggests that a more integrative tool of water management should lead future changes to the Code and the institutions governing water basins. Otherwise, the limitations and drawbacks revealed in this research will continue in the country, exacerbating inequalities, as is demonstrated in the Nuble River case. 


\subsection{Limitations in the process}

This research has aimed to include wide variety opinions to represent each of the stakeholders involved. Despite these efforts, the results of the analysis were limited by the time frame and the scale of a master's thesis. These limitations led to reduce significantly the number of participants and the length of time in the field. In addition, two key participants were reluctant to be included in the interviews. One was the regional director of Biobío Region of General Directory of Water, and the Nuble River dam project manager of Ministry of Public Works. I tried to meet with both of them during my fieldwork in several times. Both of them replied to my emails suggesting changes in time, places, and dates. Finally the technical staff of the Ministry of Public Works accepted to be interviewed but without a recorder or note taking and after work hours. I found this to be an irregular situation so I decided not to take part under those conditions. Both these men were crucial in the whole process of the design and planning of the project, so it was frustrating to not get access to their opinions.

Furthermore, the period of time chosen to do my fieldwork and interviews might not be the most appropriate because during that time of the year (MarchApril) organisations and meetings around the conflict were not active. This limited the level of participant observation I was able to undertake. I had access to two meetings during that time, but after my fieldwork there were numerous activities and events related to the case study which could have been highly interesting. However, staying longer on the field meant extra funding which I could not get, being another important constraint on fieldwork.

Finally, writing a thesis in a language (English) different to that used in fieldwork (Spanish) heightened the potential for misinterpretation in translation. This is particularly the case where there are no direct translations in the English language. However, every effort was made to provide clear translations in good English that was consistent with the intent and meaning of the research participant. 


\subsection{Further research possibilities}

It is clear that further research on the impacts of water management in Chile is necessary. Firstly, and perhaps most obviously, if the project goes ahead, it will be important to follow up on the process and effects of relocation and displacement of the 40 families most directly affected. Their experiences and narratives would be an important part within the large literature of emotional geography, displacement in the name of development and studies that are focusing on the marginalisation that result from the neoliberalisation of nature. Moreover, there are further questions as to how the dam project will affect tourism in the area, in particular those involved in the sector in San Fabián de Alico and to explore how alternatives economies will guide the area towards a well-being associated with services provided for the river.

Secondly, the model of management of the dam on the Nuble River, although yet to be finalised is likely to be shared between the Nuble River Vigilance Committee and power companies. This is the preferred approach that central Government has indicated and adopts a means of co-management that would be unique in the Chilean context, because these two groups (farmers and power companies) have historical differences with regards to water uses. Once again, it would be appropriate to follow up on this model of management from a critical perspective, especially because these stakeholders have been instrumental in articulating powerful discourses around the priority of water use in the country for development purposes.

Finally, an interesting future study would be look at how marginal livelihoods and groups have access to tradable water rights. Since changes to the Water Code in 2005, there is little evidence of the idea of pursuing more equitable control and decision - making in water management in the country. Moreover, how water has been used as a tool for development has shaped subjectivities in other sectors like mining, fisheries, forestry, etc. Further research on these sectors, would provide greater understanding of how the encounters of neoliberalism and nature has progressed in other economic sectors in Chile 


\subsection{Recommendations and suggestions}

The following recommendations are offered with the intention of complementing existing actions and in some cases proposing slightly different emphases or priorities.

1. Decentralise decision-making in the SEA. In chapter four (section 4.5), it was established that the SEA is weak and overly controlled by central decisions, lack of participation, and predominantly responds to the pressures of the exportoriented development model of the country. Consequently, the SEA needs to be more independent; sympathetic to alternate values, social impacts and environmental impacts; and to take a role that is more situated in mediation rather than just the legal administrative approval process of projects required by the SEA. 2. There is currently no entity with sole responsibility for water issues in Chile. As explained in chapter four, on one hand there is the DGA which is a department of the Ministry of Public Works managing water. On the other hand, there is a Ministry of Environment and their respective department that studies and decides on projects using water and nature. It is recommended that an interdisciplinary organisation where these actors, together with academics, researchers and members of the civil society can co-ordinate and discuss improvements in water management. Such an entity may provide useful insights and interesting studies focused in the implementation and coordination of water management within the State.

3. Appropriate mechanisms of planning according to the specific needs and potentialities of each region. The upper Nuble River illustrates the tensions between biodiversity conservation, alternate river values and economic development through agriculture. Because each region is different, there should be a legal instrument that establishes an equitable and robust process for approving large projects with high environmental costs that takes into account social, environmental and economic impacts.

4. Take account of range of different perspectives in decision-making in water management. Changes to the Water Code should be undertaken that promote 
greater local access to water. Throughout this research and other studies suggest that this tool of water management is not a good model because it privileges economic views. Considering the narratives of this research, this tool has promoted accumulation of water rights in the hands of a few which has not resulted in appropriate water governance.

\subsection{Concluding remarks}

This thesis represents a critical insight around the meanings and narratives of water used as a tool for development. The view that water is a resource, and should be managed in a technical and efficient way is nothing new. However, what I discovered in this research is that in the encounter between the neoliberal model chosen by Chile and nature, there have been diverse outcomes. In this regard, the discourses used since then have shaped the ways of decision-making both within society and most importantly in the central government. The impacts of these circumstances might not always be tangible or immediately apparent; but the conclusions of Nuble River case highlights that water governance in Chile has resulted in uneven effects, especially for those marginal population groups. The power relations and how dominant knowledge marginalises alternative ways of living have shaped subjectivities both in managing water and using nature. Conflict

as the Nuble River case highlight that there are still spaces of resistance against the compelling notion that the market is the most effective way of managing nature, which creates possibilities for alternatives to emerge.

I hope this research will provide an example for organisations in Chile, and that they can provide deeper insights into current water management and the potential for uneven and unjust effects. 


\section{References}

Altieri, M., \& Rojas, A. (1999). Ecological Impacts of Chile's Neoliberal Policies with Special Emphasis on Agroecosystems Environment, Development and Sustainability 1, 55-72.

Amezaga, J. M., Rotting, T. S., Younger, P. L., Nairn, R. W., Noles, A.-J., Oyarzun, R., et al. (2011). A Rich Vein? Mining and the Pursuit of Sustainability. Environmental Science \& Technology, 45, 21-26.

Amigo, J., \& Ramírez, C. (1998). A Bioclimatic Classification of Chile: Woodland Communities in the Temperate Zone. Plant Ecology, 136, 9-26.

Bakker, K. (2003). Archipelagos and Networks: Urbanization and Water Privatization in the South. The Geographical Journal, 169(4), 328-341.

Bakker, K. (2005). Neoliberalizing Nature? Market Environmentalism in Water Supply in England and Wales. Annals of the Association of American Geographers 95(3), 542-565.

Bakker, K. (2007). The "Commons" Versus the "Commodity": Alterglobalization,Anti-privatization and the Human Right to Water in the Global South. Antipode, 39(3), 430-455.

Bakker, K. (2010). The limits of 'neoliberal natures': Debating green neoliberalism. Progress in Human Geography, 34(6), 715-735.

Bastias, A. (2010). Impactos de la Modernidad y Posmodernidad en las Comunidades, San Fabian de Alico, Chile. Comunidades: Transformacion Constante(Cuaderno de Trabajo Vol 8).

Bauer, C. J. (1997). Bringing Water Markets Down to Earth: The Political Economy of Water Rights in Chile, 1976-95. World Development, 25(5), 639-656.

Bauer, C. J. (1998). Against the Current Privatisation, Water Markets, and the State in Chile. Natural Resources Management and Policy.

Bauer, C. J. (2004). Results of Chilean Water Markets: Empirical Research Since 1990. Water Resources Research 40.

Bauer, C. J. (2005). In the Image of the Market: The Chilean Model of Water Resources Management. International Journal of Water, 3(2), 146-166.

Bauer, C. J. (2009). Dams and Markets: Rivers and Electric Power in Chile. Natural Resources Journal, 49, 583-653.

Bauer, C. J. (2010). Market Approachs to Water Allocation: Lessons from Latin America. Journal of Contemporary Water Research and Education, 144, 4449.

Bennett, J. (2010). Vibrant Matter: A Political Ecology of Things. Durham: Duke University Press.

Berkes, F. (1999). Sacred Ecology: Traditional Ecological Knowledge and Resource Management. Philadelphia, PA: Taylor \& Francis.

Berkes, F. (2004). Rethinking Community-Based Conservation. Conservation Biology, 18(3), 621-630. 
Berkes, F., Colding, J., \& Folke, C. (2000). Rediscovery of Traditional Ecological Knowledge as Adaptive Management. Ecological Applications, 10(5), 12511262.

Boelens, R. (2009). The Politics of Disciplining Water Rights. Development and Change, 40(2), 307-331.

Bondi, L., \& Laurie, N. (2005). Introduction. In N. Laurie \& L. Bondi (Eds.), Working the Spaces of Neoliberalism. Oxford, UK: Blackwell Publishing.

Bradshaw, M., \& Stratford, E. (2005). Qualitative Research Design and Rigour. In I. Hay (Ed.), Qualitative Research Methods in Human Geography. South Melbourne, Australia: Oxford University Press.

Briscoe, J., Anguita, P., \& Peña, H. (1998). Managing Water as an Economic Resource: Reflections on the Chilean Experience: Environment Department Paper No.62. Washington, DC: World Bank.

Brockington, D., \& Sullivan, S. (2003). Qualitative research. In R. Scheyvens \& D. Storey (Eds.), Development fieldwork: a practical guide (pp. 57 - 77). London: Sage.

Brohman, J. (1996). Popular Development. Oxford, UK.

Malden, Massachusetts, USA: Blackwell Publishers Ltd.

Budds, J. (2004). Power, nature and neoliberalism: the political ecology of water in Chile. Singapore Journal of Tropical Geography, 25(3), 322-342.

Budds, J. (2009). Contested $\mathrm{H}_{2} \mathrm{O}$ : Science, Policy and Politics in Water Resources Management in Chile. Geoforum, 40, 418-430.

Budds, J., \& McGranahan, G. (2003). Are the Debates on Water Privatization Missing the Point? Experiences from Africa, Asia and Latin America. Environment and Urbanization, 15(2), 87-114.

Carruthers, D. (2001). Environmental Politics in Chile: Legacies of Dictatorship and Democracy. Third World Quarterly, 22(3), 343-358.

Castillo, M. (1998). Análisis Crítico del Sistema de Evaluación de Impacto Ambiental, Ley 19.300. Santiago:Chile: Red Nacional de Acción Ecológica.

Castree, N. (2005). Nature. London: Routledge.

Castree, N. (2008a). Neoliberalising Nature: Processes, Effects, and Evaluations. Environment and Planning A, 40, 153-173.

Castree, N. (2008b). Neoliberalising Nature: The Logics of Deregulation and Reregulation. Environment and Planning A, 40, 131-152.

Castree, N. (2011). Neoliberalism and the Biophysical Environment 3: Putting Theory into Practice. Geography Compass, 5(1), 35-49.

Cawley, M., \& Gillmor, D. A. (2008). Integrated Rural Tourism: Concepts and Practice. Annals of Tourism Research 35(2), 316-337.

CEPAL. (2005). Aglomeraciones en Torno a los Recursos Naturales en América Latina y el Caribe: Políticas de Articulación y Articulación de Políticas. Santiago de Chile: Naciones Unidas.

Challies, E. R. T., \& Murray, W. (2008). Towards post-neoliberalism? The comparative politico-economic transition of New Zealand and Chile. Asia Pacific Viewpoint, 29(2), 228-243.

Chambers, R. (1989). Vulnerability, Coping and Policy. Institute of Development Studies Bulletin, 20, 1-7. 
Chambers, R. (1997). Whose Reality Count?: Putting the First Last. London: Intermediate Technology Publications.

Chambers, R. (2005). Ideas for Development. Sterling, VA: Earthscan.

ChileRiego. (n.d.). Retrieved 25 October, 2012,from, http://www.chileriego.cl/opensite_20051129121756.aspx.

Craig, D., \& Porter, D. (2006). Development Beyond Neoliberalism? London \& New York: Routledge.

Crang, M., \& Cook, I. (2007). Doing Ethnographies. London: SAGE Publications Ltd.

Creswell, J. W. (2003). Research Design: Qualitative, Quantitative, and Mixed Methods Approaches. Thousand Oaks, California: Sage Publications.

Cronon, W. (1996). The Trouble with Wilderness or, Getting Back to the Wrong Nature. Environmental History, 1(1), 7-28.

de la Cadena, M., \& Starn, O. (2007). Indigenous Experience Today. New York, USA: Oxford International Publishers Ltd.

Dean, M. (2010). Governmentality. Power and Rule in Modern Society. London: SAGE.

Demeritt, D. (1996). Social Theory and the Reconstruction of Science and Geography. Royal Geographical Soceity, 21(3), 484-503.

Demeritt, D. (2001). The Construction of Global Warming and the Politics of Science. Annals of the Association of American Geographers, 91(2), 307337.

Denscombe, M. (1998). The Good Research Guide for Small Scale Social Research Projects Buckingham: Open University Press.

Denzin, N. K., \& Lincoln, Y. S. (Eds.). (1994). Handbook of Qualitative Research. Thousand Oaks, London, New Dheli.

Desai, V., \& Potter, R. (2008). The Companion to Development Studies. London.

Domper, M. (2009). Chile: A Dynamic Water Market Libertad y Desarrollo. Santiago:Chile.

Dubash, N. (2004). Water, Markets, and Embedded Institutions in Western India. In R. Peet \& M. Watts (Eds.), Liberation Ecologies. Environment, Development, Social Movements (2nd edition) (pp. 218-243). London: Routledge.

Duffy, R. (2005). The Politics of Global Environmental Governance: The Powers and Limitations of Transfrontier Conservation Areas in Central America. Review of International Studies, 31(2), 307-323.

El-Observatorio-Politico. (2011). Retrieved 17 July,2012,from, http://elobservatorio-politico.blogspot.co.nz/2011/12/inician-lobby-para-acelerarobras-del.htmlwww.el-observatorio-politico.blogspot.com.

England, K. V. L. (1994). Getting Personal: Reflexivity, Positionality, and Feminist Research The Professional Geographer, 46(1), 80-89.

Escobar, A. (1996). Constructing nature:Element for a poststructural political ecology. In R. Peet \& M. Watts (Eds.), Liberation ecologies:Environment, development, social movements (pp. 46-68). London: Routledge Kegan Paul.

Escobar, A. (1998). Whose Knowledge, Whose Nature? Biodiversity, Conservation, and the Political Ecology of Social Movements. Journal of Political Ecology, 5, 53-82.

Fisher, K. T. (2008). Politics and Urban Water Supply. Development, 51, 30-36. 
Fisher, K. T. (2009). Urban Water Supply and Local Neoliberalism in Tagbilaran City, The Philippines. Asia Pacific Viewpoint 50(2), 185-197.

Fleming, D., Abler, D., \& Goetz, S. (2010). Agricultural Trade and Poverty in Chile: A Spatial Analysis of Product Tradability. Agricultural Economics, 41, 545553.

Foucault, M. (1978). Governmentality. In J. D. Faubion (Ed.), Power. Essential Works of Foucault 1954-1984. London, England: Penguin Group.

Foucault, M. (1991). Governmentality. In G. Burchell, C. Gordon \& P. Miller (Eds.), The Foucault Effect: Studies in Governmentality (pp. 87-104). Chicago, USA: University of Chicago.

Galaz, V. (2004). Stealing from the Poor? Game Theory and the Politics of Water Markets in Chile. Environmental Politics, 13(2), 414-437.

Garande, T., \& Dagg, S. (2005). Public Participation and Effective Water Governance at the Local Level : A Case Study from a Small UnderDeveloped Area in Chile. Environment, Development and Sustainability, 7, 417-431.

Gazmuri-Schleyer, R. (1996). Chilean Water Policy: The Role of Water Rights, Institutions and Markets. International Journal of Water Resources Development, 12(1), 33-48.

Gentes, I. (2008). Las Aguas Transadas. Hacia una Evaluacion del Impacto Social y Ambiental del Mercado de Derechos de Agua en Chile. In D. Soares, M. R. Nuno \& S. Vargas (Eds.), La Gestion de los Recursos Hidricos; Realidades y Perspectivas (pp. 1-35). Mexico D.F.: Instituto Mexicano de Tecnologia del Agua (IMTA) / Universidad de Guadalajara.

Glesne, C. (2006). Becoming Qualitative Researchers. An Introduction. Boston, United States of America: Pearson Education.

Gregorio, J. D., \& Labbé, F. (2011). Copper, The Real Exchange Rate and Macroeconomic Fluctuations in Chile.

Guioteca. (2012). retrieved 6 October, 2012, from http://www.guioteca.com/temaslegales/evaluacion-ambiental-de-chile-frente-a-la-ocde/.

Gunderson, L., Carpenter, S., Folke, C., Olsson, P., \& Peterson, G. (2006). Water RATs (Resilience, Adaptability, and Transformability) in Lake and Wetland Social-Ecological Systems. Ecology and Society, 11(1), :16.

Gwynne, R. (1999). Globalisation, Commodity Chains and Fruit Exporting Regions in Chile. Journal of Economic and Social Geography, 90(2), 211-225.

Hajer, M. A. (2005). Coalitions, Practices, and Meaning in Environmental Politics: From Acid Rain to BSE. In D. Howarth \& J. Torfing (Eds.), Discourse Theory in European Politics: Identity, Policy and Governance (pp. 297-315). New York: Palgrave Macmillan.

Harvey, D. (2003). The New Imperialism. Oxford: Oxford University Press.

Harvey, D. (2005). A Brief History of Neoliberalism. New York, United States: Oxford University Press.

Hay, I. (1998). Making Moral Imaginations. Research Ethics, Pedagogy, and Professional Human Geography. Philosophy \& Geography, 1(1), 55-75.

Heynen, N., \& Robbins, P. (2005). The Neoliberalization of Nature: Governance, Privatization, Enclosure and Valuation. Capitalism Nature Socialism, 16(15). 
Howarth, D. (2000). Discourse. Concepts in the Social Sciences Buckingham: Open University Press.

Howitt, R., \& Stevens, S. (2005). Cross-Cultural Research: Ethics, Methods, and Relationships. In I. Hay (Ed.), Qualitative Research Methods in Human Geography. South Melbourne, Australia: Oxford University Press.

Jenks, J. J. (2009). Water Rights and Markets in Chile: Efficiency and Social Equity in Agricultural Irrigation. Thesis submitted for the obtation of the degree of Master of Arts in Development Studies, International Institute of Social Studies, The Hague.

Jimenez, S. (2012). Piñera Frena Impaciencia de Agricultores y Llama a Hacer Bien las Cosas en La Punilla. Diario La Discusion, Chillan, 24 February 2012, p. 6.

Kaika, M. (2006). Dams as Symbols of Modernization: The Urbanization of Nature Between Geographical Imagination and Materiality. Annals of the Association of American Geographers, 96(2), 276-301.

Kitchin, R., \& Tate, N. J. (2000). Conducting Research into Human Geography. Theory, Methodology \& Practice. Harlow, United Kingdom: Pearson Education Limited.

Kobayashi, A. (2009). Geographies of Peace and Armed Conflict: Introduction. Annals of the Association of American Geographers 99(5), 819-826.

Kvale, S. (Ed.). (1996). Interviews. An Introducction to Qualitative Research Interviewing. Thousand Oaks, California: SAGE Publications.

LaDiscusion, D. (2012). retrieved 2 October, 2012, from http://www.diarioladiscusion.cl/index.php/economia/105economia2130579610/16168-gobierno-fija-para-julio-de-2013-licitaciondel-embalse-la-punilla.

Langridge, R., Christian-Smith, J., \& Lohse, K. A. (2006). Access and Resilience: Analyzing the Construction of Social Resilience to the Threat of Water Scarcity. Ecology and Society, 11(2), :18.

Larner, W. (2000). Neo-liberalism: Policy, Ideology, Governmentality. Studies in Political Economy, 63, 5-25.

Latta, A. P. (2011). Citizenship and the Politics of Nature: The Case of Chile's Alto Bío Bío. Citizenship Studies, 11(3), 229-246.

LeCompte, M. D., \& Schensul, J. J. (1999). Design and Conduct Ethnographic Research. London: Sage Publications.

Li, T. M. (2007a). Governmentality. Anthropologica 49(2), 275-281.

Li, T. M. (2007b). The Will to Improve. Governmentality, Development, and the Practice of Politics. Durham \& London: Duke University Press.

Liverman, D., \& Vilas, S. (2006). Neoliberalism and the Environment in Latin America. Annual Review, 29, 327-363.

Loftus, A. (2009). Rethinking Political Ecologies of Water. Third World Quarterly, 30(5), 953-968.

Mansfield, B. (2004). Neoliberalism in the Oceans: "Rationalization", Property Rights, and the Commons Questions. Geoforum, 35, 313-326.

Mares, D., \& Martin, J. (2012). Regional Energy Integration in Latin America: Lessons from Chile's Experience with Natural Gas. Third World Quarterly, 33(1), 55-70. 
McAfee, K., \& Shapiro, E. N. (2010). Payments for Ecosystem Services in Mexico: Nature, Neoliberalism, Social Movements, and the State. Annals of the Association of American Geographers, 100(3), 579-599.

McCarthy, J., \& Prudham, S. (2004). Neoliberal nature and the nature of neoliberalism. Geoforum, 35, 275-283.

McKee, K. (2009). Post-Foucauldian Governmentality: What does it Offer Critical Social Policy Analysis? Critical Social Policy, 29(3), 465-486.

Metha, L. (2003). Problems of Publicness and Access Rights : Perspectives from the Water Domain. In I. Kaul, P. Conceicao, K. L. Goulven \& R. Mendoza (Eds.), Providing Global Public Goods: Managing Globalisation (pp. 556575). New York: Oxford University Press.

Mikkelsen, B. (2005). Methods for Development Work and Research. A New Guide for Practitioners (2nd ed.). New Dehli: SAGE Publications.

MINENERGIA. (2012). Retrieved 30 November, 2012, from http://www.minenergia.cl/estrategia-nacional-de-energia-2012.html.

MINSEGPRES. (1997). Reglamento del Sistema de Evaluación de Impacto Ambiental: Decreto Supremo 30/97.

Mullings, B. (1999). Insider or Outsider, Both or Neither: Some Dilemmas of Interviewing in a Cross-cultural Setting. Geoforum, 30, 337-350.

Murray, W. (2002). From Dependency to Reform and Back Again: The Chilean Peasantry During the Twentieth Century. Journal of Peasant Studies, 29(34), 190-227.

Murray, W. (2009). Neoliberalism and Development In R. Kitchin \& N. Thrift (Eds.), International Encyclopedia of Human Geography (pp. 111-116). Oxford: Elsevier Ltd.

Namuncura, D. (1999). Ralco: Represa o Pobreza? Santiago: LOM Ediciones.

Ormazábal, C. (1997). Sistema de Evaluación de Impacto Ambiental: Análisis Crítico del Marco Legal y su Reglamento. Ambiente y Desarrollo, 13(3), 47-51.

Oyarzún, J., \& Oyarzún, R. (2011). Sustainable Development Threats, Inter-sector Conflicts and Environmental Policy Requirements in the Arid, Mining Rich, Northern Chile Territory. Sustainable Development, 19(4), 263-274.

Peck, J., \& Tickell, A. (2002). Neoliberalizing Space. Antipode, 34(3), 380-404.

Perreault, T., \& Martin, P. (2005). Geographies of Neoliberalism in Latin America. Environment and Planning A, 37, 191-201.

Pladeco. (2008). Retrieved 15 January, 2013, from http://www.sanfabian.cl/documentos/doc_003_100319080355.PDF.

Potter, J. (2008). Discourse Analysis. In L. M. Given (Ed.), The SAGE Encyclopedia of Qualitative Research Methods (pp. 217-220). Los Angeles: SAGE Publications.

Prieto, M., \& Bauer, C. (2012). Hydroelectric Power Generation in Chile: An Institutional Critique of the Neutrality of Market Mechanisms. Water International, 37(2), 131-146.

Punilla. (n. d.). Retrieved 15 of August, 2011, from http://www.punilla.cl/.

Qizilbash, M. (1996). Ethical Development. World Development, 24(7), 1209-1221.

RedBiobio. (2012). retrieved 2 October, 2012 , from http://www.redbiobio.com/2012/07/14/diputado-sauerbaum-rn-valoramodelo-de-negocios-que-permitira-financiar-el-embalse-punilla/. 
RioNuble. (n.d.). Retrieved 25 September,2012 from, www.rionuble.cl.

Robbins, P. (2012). Political Ecology. Critical Introductions to Geography (2nd ed.). Oxford,UK: Wiley-Blackwell.

Robbins, P., \& Luginbuhl, A. (2005). The Last Enclosure: Resisting Privatization of Wildlife in the Western United States. Capitalism Nature Socialism, 16(1), 45-61.

Rojas, A., Sabatini, F., \& Sepulveda, C. (2003). Conflictos Ambientales en Chile: Aprendizajes y Desafíos. Ambiente y Desarrollo, 19(2), 22-30.

Romero-Toledo, H., Romero-Aravena, H., \& Toledo-Olivares, X. (2009). Agua, Poder, y Discursos: Conflictos Socio-Territoriales por la Construcción de Centrales Hidroeléctricas en la Patagonia Chilena. Anuario de Estudios Americanos, 66(2), 81-103.

Rose, G. (1997). Situating Knowledges: Positionality, Reflexivities and other Tactics. Progress in Human Geography, 21(3), 305-320.

Salazar, G., \& Pinto, J. (1999). Historia Contemporánea de Chile I: Estado, Legitimidad, Ciudadanía. Santiago,Chile: LOM.

Scheyvens, R. (2002). Tourism for Development. Empowering Communities Essex, England: Pearson Education Limited.

Scheyvens, R., \& Storey, D. (Eds.). (2003). Development Fieldwork. A Practical Guide. London, Thousand Oaks, New Delhi: SAGE Publications Ltd.

Seia. (2011). Retrieved 12 January, 2013, from http://www.e-seia.cl/seiaweb/ficha/fichaPrincipal.php?modo=ficha\&id_expediente=6295.

Sepúlveda, C., \& Rojas, A. (2010). Conflictos Ambientales y Reforma Ambiental en Chile: Una Oportunidad Desaprovechada de Aprendizaje Institucional sobre Participación Ciudadana. Ambiente y Desarrollo, 24(2), 15-23.

Sepulveda, C., \& Villaroel, P. (2012). Swans, Conflicts, and Resonance: Local Movements and the Reform of Chilean Environmental Institutions. Latin American Perspectives 39(4), 181-200.

Sharpley, R. (2002). Tourism: A vehicle for Development? In R. Sharpley \& D. J. Telfer (Eds.), Tourism and Development. Concept and Issues. Clevedon, United Kingdom: Channel View Publications.

Silva, E. (1996). Democracy, Market Economics, and Environmental Policy in Chile. Journal of Interamerican Studies and World Affairs, 38(4), 1-33.

Smith, M., Davidson, J., Cameron, L., \& Bondi, L. (Eds.). (2009). Emotion, Place, and Culture. Aldeshort, England: Ashgate.

Sultana, F. (2007). Reflexivity, Positionality and Participatory Ethics: Negotiating Fieldwork Dilemmas in International Research. ACME: An International EJournal for Critical Geographies, 6(3), 374-385.

Sultana, F. (2009). Community and Participation in Water Resources Management: Gendering and Naturing Development Debates from Bangladesh. Transactions of the Institute of British Geographers, New Series, 34, 346363.

Sultana, F. (2011). Suffering for Water, Suffering from Water: Emotional Geographies of Resources Access, Control, and Conflict. Geoforum, 42, 163-172. 
Sultana, F. (2012). Water, Technology, and Development: Transformations of Development Technonatures in Changing Waterscapes. Environment and Planning D: Society and Space, 30, 1-16.

Sustentable. (n.d.). Retrieved 25 October, 2012, from, http://www.sustentable.cl/noticias_extendida.php?nid=6174.

Swyngedouw, E. (2004). Social Power and the Urbanization of Water: Flows of Power. Oxford: Oxford University Press.

Swyngedouw, E. (2005). Dispossessing $\mathrm{H}_{2} \mathrm{O}$ : The Contested Terrain of Water Privatization. Capitalism, Nature, Socialism, 16(1), 81-98.

Swyngedouw, E. (2009). The Political Economy and Political Ecology of the HydroSocial Cycle. Journal of Contemporary Water Research and Education(142), 56-60.

Tecklin, D., Bauer, C., \& Prieto, M. (2011). Making Environmental Law for the Market: the Emergence, Character, and Implications of Chile's Environmental Regime. Environmental Politics 20(6), 879-898.

TerraChile. (2012). retrieved 2 October, 2012, from http://noticias.terra.cl/terraverde/diputado-sauerbaum-rn-anuncia-reunion-con-titular-del-mop-porembalse-punilla,15fcc752eb75b310VgnCLD2000000dc6eb0aRCRD.html.

Timothy, D. J. (2002). Tourism and Community Development Issues In R. Sharpley \& D. J. Telfer (Eds.), Tourism and Development. Concepts and Issues. Clevedon, United Kingdom: Channel View Publications.

Torres, R., \& García, A. (2009). Conflictos por el Agua en Chile: El gran Capital contra las Comunidades Locales. Análisis Comparativo de las Cuencas de los ríos Huasco (Desierto de Atacama) y Baker (Patagonia Austral). Espacio Abierto, 18(4), 695-708.

TVU. (2011). $\quad$ Retrieved 28 July, 2012, from http://www.tvu.cl/noticias/index.php?option=com_content\&view=article\&id= 4673\%3Aministro-de-agricultura-estuvo-en-el-primer-encuentro$\underline{\text { forestal-realizado-en-sur-activo\&catid }=11 \% 3 \text { Acronica \&Itemid }=1}$ www.tvu.cl.

UNESCO. (2011). Retrieved 14 November, 2012, from, http://www.unesco.org/new/en/natural-sciences/environment/ecologicalsciences/biosphere-reserves/latin-america-and-thecaribbean/chile/corredor-biologico-nevados-de-chillan-laguna-del-laja/.

UNPD. (2011). Retrieved 16 November, 2012, from http://hdrstats.undp.org/en/countries/profiles/CHL.html.

Urkidi, L. (2010). A Glocal Environmental Movement Against Gold Mining: PascuaLama in Chile. Ecological Economics, 70(2), 219-227.

Waitt, G. (2005). Doing Discourse Analysis. Qualitative Research Methods in Human Geography.

Watts, M. (2000). Political Ecology A Companion to Economic Geography (pp. 257274). Oxford: Blackwell.

Watts, M. (2003). Alternative Modern - Development as Cultural Geography. In K. Anderson, M. Domosh, S. Pile \& N. Thrift (Eds.), Handbook of Cultural Geography (pp. 433-454). London,Thousand Oaks,New Delhi: SAGE Publications Ltd. 
Watts, M., \& Peet, R. (2004). Liberating Political Ecology. In R. Peet \& M. Watts (Eds.), Liberation Ecologies: Environment, Development, Social Movements (2nd edition) (pp. 3-47). London: Routledge.

White, D. (2006). A Political Sociology of Socionatures: Revisionist Manoeuvres in Environmental Sociology. Environmental Politics, 15(1), 59-77.

Willis, K. D., \& Kumar, M. S. (2009). Development I. In R. Kitchin \& N. Thrift (Eds.), International Encyclopedia of Human Geography. Amsterdam, The Netherlands; Oxford, United Kingdom: Elsevier.

Winchester, H. P. M. (2005). Qualitative Research and its Place in Human Geography. In I. Hay (Ed.), Qualitative Research Methods in Human Geography. South Melbourne, Australia: Oxford University Press.

Yáñez, N., \& Molina, R. (2011). Las Aguas Indígenas en Chile Santiago de Chile: LOM Ediciones.

Zimmerer, K. S. (2011). The Landscape Technology of Spate Irrigation amid Development Changes: Assembling the Links to Resources, Livelihoods, and Agrobiodiversity-Food in the Bolivian Andes Global Environmental Change, 21, 917-934. 


\title{
Appendix One - Ethics forms
}

\author{
Information sheet for participants in English:
}

Participant Information Sheet for a Study of Punilla Projected Dam Ñuble River, Bio Bio Region, Chile

Researcher: Cristian Leaman-Constanzo: School of Geography, Environment and Earth Sciences, Victoria University of Wellington.

I am a Masters student in Development Studies at Victoria University of Wellington. I am undertaking a research project leading to a thesis. The project I am undertaking is to investigate how neoliberal ideas have faced encounters with nature, and how these encounters have been adopted by different stakeholders through a particular case study (Punilla Projected Dam in Nuble River, Bio Bio Region, Chile). Ethics approval has been obtained from Victoria University of Wellington for research involving human participants.

\section{Interview Format}

This interview will take approximately 30 - 60 minutes of your time and will be audio recorded. It is based on a semi-structured format so the exact nature of the questions has not been determined in advance but will depend on the way that the interview develops. Should the line of questioning progress in a way that makes you uncomfortable you can decline to answer any question(s).

\section{Participation}

Your participation is completely voluntary and you can leave the interview at any time and retract any statements made before 30 November 2012 without any disadvantage to yourself.

On the attached consent form, you are given the option of using your real name, an organisation's name, or a code name to maintain confidentiality (for instance, participant one). Because of the nature of the project, anyone who is very familiar with the specific event, movement or campaign may be able to connect statements to particular groups or individuals. However, please be assured that should you request confidentiality, every effort will be made to make sure you cannot be easily identified.

\section{Data Use and Storage}

Responses collected will form the basis of my research project and will be put into a written report (Master thesis). The data collected may also be used in an academic journal article and that the research may form the basis of conference presentations, a 
book or further funding applications to continue exploring issues associated with the project.

It will not be possible to identify you personally in these publications. Individual quotes or statements may be used but will only refer to the level of study you are undertaking (eg participant \# 10; regional government). All material will be kept confidential. The data collected will be securely stored in such a way that only myself and my supervisor, Dr Sophie Bond will be able to gain access to it. If you would like a copy of the final report from the project, indicate appropriately on the consent form. You may also receive a copy of any interview transcript and request changes if you wish. This data will be stored securely for a period of five years, then any personal information will be destroyed immediately, except that on which published results rely.

If you have any questions or would like to receive further information about the project, please contact either Cristian Leaman-Constanzo or Dr Sophie Bond, School of Geography, Environment and Earth Sciences; Victoria University of Wellington, P O Box 600, Wellington

Cristian Leaman-Constanzo

cleamanc@yahoo.com

$\mathrm{Ph} 64+04+4639463$
Dr Sophie Bond

sophie.bond@vuw.ac.nz

$\mathrm{Ph} 64+04+4635217$ 


\section{Information sheet for participants in Spanish:}

\section{Hoja de información para los participantes del proyecto de investigación académica, Embalse Punilla, rio Nuble, Región del Biobío, Chile (Spanish)}

Investigador académico: Cristian Leaman Constanzo, Escuela de Geografía, Medio Ambiente y Ciencias de la Tierra, Universidad de Victoria de Wellington.

Yo soy un estudiante del Magister de Estudios de Desarrollo de la Universidad de Victoria de Wellington y estoy realizando este proyecto de investigación que conduce a mi tesis. El proyecto que estoy llevando a cabo es investigar como el modelo económico neoliberal de Chile ha manejado los encuentros con la naturaleza, y como estos encuentros han sido adoptados y manejados por diferentes actores y comunidades en el mundo rural. Pare ello, he elegido este caso de estudio del rio Nuble para ejemplificar lo expuesto anteriormente.

Para esto, la Universidad de Victoria de Wellington aprobó con fecha del 5 de Diciembre del 2011 un compromiso de ética de este investigador debido a que esto involucra la participación de personas en este estudio.

\section{Formato de la entrevista}

La entrevista durara aproximadamente 30 a 60 minutos y será grabada a través de una grabadora de audio. Esta será basada en un formato de entrevista semi-estructurada que implica que si bien hay preguntas ya definidas para hacer, también deja abierta la opción de realizar otras preguntas dependiendo del flujo de la conversación.

En caso de que durante la entrevista Ud. se siente incomodo/a con las preguntas o la manera de preguntar, Ud. puede negarse a responder.

\section{Participación}

Su participación es completamente voluntaria y Ud. puede dejar la entrevista en cualquier momento y/o retractarse de alguna declaración o comentario hecho por Ud. antes del 30 de Noviembre del 2012 sin ninguna implicancia para Ud.

En el formulario de consentimiento, Ud. tiene la opción de usar su nombre real, o el nombre de su organización. También, Ud. puede optar a usar un número de código que le permitirá mantener sus comentarios en completa confidencialidad. Todo esto para proteger sus comentarios de cualquier mal uso en contra de Ud. o de su organización que pudiera implicar otras consecuencias que están fuera del ámbito de este estudio. 


\section{Uso y almacenamiento de los datos}

Los comentarios y respuestas de esta entrevista serán usados en mi proyecto de investigación y podrán ser incorporados a mi tesis de postgrado u otros informes. La información recopilada también podría ser usada en revistas académicas, como parte de presentaciones en conferencias, seminarios, libros $\mathrm{y} / \mathrm{u}$ otros proyectos académicos asociados a este estudio. No será posible, sin embargo, identificar a Ud. personalmente en estas publicaciones, a menos que Ud. quiera. Citas o declaraciones se podrán utilizar, pero solo se referirán al estudio que se esta llevando a cabo. Todo el material se mantendrá en completa confidencialidad. Los datos recogidos serán almacenados de forma segura, de tal manera que sólo yo y mi supervisora de tesis Dr. Sophie Bond podremos tener acceso a esa información. Si Ud. desea una copia del informe final del proyecto, puede indicarlo en el formulario de consentimiento. También puede recibir una copia de la transcripción de la entrevista y solicitar cambios si lo desea. Estos datos se almacenaran de forma segura durante un período de cinco años, entonces cualquier información personal será destruida de inmediato, salvo aquellos en la cual los resultados publicados se basan.

Si tiene cualquier pregunta o quiere recibir información adicional sobre el proyecto, por favor póngase en contacto con mi persona, Cristian Leaman Constanzo, o si lo desea con la Dr. Sophie Bond de la Escuela de Geografía, Medio Ambiente y Ciencias de la Tierra; Universidad de Victoria de Wellington (School of Geography, Environment and Earth Sciences; Victoria University of Wellington, P O Box 600, Wellington)

Cristian Leaman-Constanzo

cleamanc@yahoo.com

Fono Nueva Zelandia 64+04+4635767

Fono Chile $\quad 9+62422592$
Dr Sophie Bond

sophie.bond@vuw.ac.nz

Fono 64+04+ 4635217 


\section{Consent form for participants in English:}

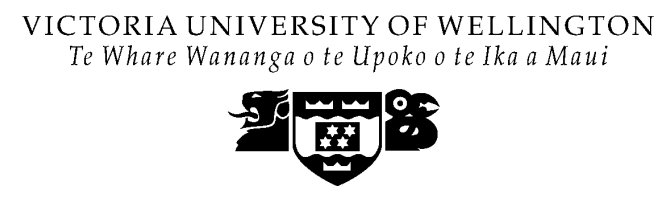

Consent for a study of Punilla Projected Dam, Nuble River, Bio Bio Region, Chile (English)

I have read and understood the information sheet and I understand that I can request more information at any stage

$\mathrm{Y} / \mathrm{N}$

I am aware that participation is purely voluntary and I can withdraw at any time, refuse to answer any questions, or retract any statements before 30 November 2012 without disadvantage

$\mathrm{Y} / \mathrm{N}$

I consent to my real name being used in publications

$\mathrm{Y} / \mathrm{N}$

If no, I would like to be identified using: (please tick one)

The name of an organisation (please identify)

A code name

Other: (please identify)

I understand that the information I give will not be used for any purpose other than those listed below and in the information sheet without my consent

$\mathrm{Y} / \mathrm{N}$

I understand I will have the chance to check the transcripts prior to publication and make any comments

$\mathrm{Y} / \mathrm{N}$

I would like to receive a final report of the findings at the conclusion of the research

$\mathrm{Y} / \mathrm{N}$

If yes, my address is:

And my email address is:

$\mathrm{I}$, consent to being interviewed and audio recorded by Cristian Leaman-Constanzo for the purposes of the research project and producing one or more journal articles, presentations at conferences or further funding applications.

Signed:

Date: 


\section{Consent form for participants in Spanish:}
VICTORIA UNIVERSITY OF WELLINGTON
Te Whare Wananga o te Upoko o te Ika a Maui

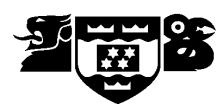

Permiso para un estudio del proyecto de embalse Punilla, rio Nuble, Region del Bio Bio, Chile

Formulario de Acuerdo

Yo he leído y entendido la hoja de información y comprendo que puedo requerir más información en cualquier etapa de este estudio.

$\mathrm{Y} / \mathrm{N}$

Yo estoy consciente que mi participación es puramente voluntaria y que yo me puedo retirar en cualquier momento, o rechazar responder algunas preguntas, o retractarme de algunas declaraciones antes del 30 de Noviembre del 2012 sin ninguna inconveniente para mí.

\section{$\mathrm{Y} / \mathrm{N}$}

Doy mi consentimiento que mi verdadero nombre sea usado en publicaciones

\section{$\mathrm{Y} / \mathrm{N}$}

De lo contrario, me gustaría ser identificado usando (por favor, elija una de las siguientes opciones)

\section{Nombre de la organización/institución (por favor, identifíquela)}

Un nombre con codigo

Otro: (por favor, identifíquela)

Yo entiendo que la información que entregare no será usada para otros propósitos distintos a los nombrados más abajo y en la hoja de información sin mi consentimiento.

$\mathrm{Y} / \mathrm{N}$

Yo entiendo que tendré la oportunidad de revisar las transcripciones previas a la publicación y podría hacer algunos comentarios finales

$\mathrm{Y} / \mathrm{N}$

Me gustaría recibir un informe con los resultados al final de este estudio $\quad \mathrm{Y} / \mathrm{N}$

Si su respuesta es sí, indique su dirección:

Y su correo electrónico es:

Yo, doy mi consentimiento para ser entrevistado y grabado por Cristian Leaman-Constanzo con el fin de de aportar a un proyecto de investigación cual podría ser publicado en uno o más artículos de revistas de investigación, o ser usado para presentaciones en conferencias y seminarios u otras fines académicos.

Firma:

Fecha: 


\title{
Interview schedule for participants in English:
}

\author{
VICTORIA UNIVERSITY OF WELLINGTON \\ Te Whare Wananga o te Upoko o te Ika a Maui
}

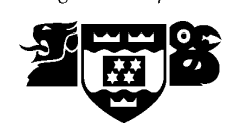

Encounters of neoliberalism and nature in the Chilean context. A case study of Nuble River, Bio Bio region, Chile

\section{Interview Schedule}

1. Tell me about your background.

2. How long have you been involved in this organisation/institution? What motivated you to get involved? What role did you play in the organisation/institution?

3. What is your relationship with the Nuble River and its communities?

4. Tell me about Punilla Projected Dam:

i. Do you see any conflict in this project?

ii. What do you think might be some solutions in this conflict/issue?

5. What factors have addressed the process of decision-making in relation to water management in this dam project? Do you consider that other factors should be added in the process? Which ones?

6. How has information been provided for all the people involved in this project? Has it been accessible for everyone?

7. How has your organisation/institution sought to cultivate links with other organisations (both national and international)?

8. What arguments or positions do different groups preesent in this project?

9. What are the social networks that you have identified for each stakeholder involved in this case? To what extent your organisation/institution and others should be taking on board of this process?

10. How would you like to see Nuble River in the future? How should the river be managed? And by whom?

11. How do you understand the role of the river in this area? 
Interview schedule for participants in Spanish:

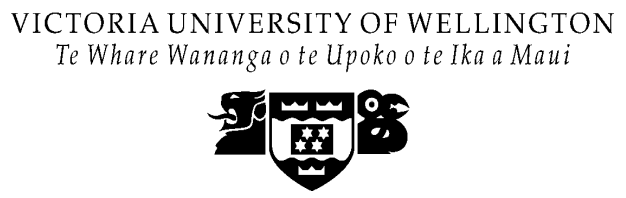

Encuentros de neoliberalismo y naturaleza en el contexto chileno. Un caso de estudio del rio Ñuble, Region del Bio Bio, Chile.

\section{Programa de la entrevista}

1. Cuénteme acerca de quién es Usted y su historia

2. Cuanto tiempo ha estado involucrado en esta organización/institución. Que lo motivo a Usted a estar involucrado en esta organización/institución. Cuál es su función en esta organización/institución?

3. Cuál es su relación con el rio Nuble y sus comunidades?

4. Cuénteme acerca del proyecto Punilla:

i. Usted ve algún conflicto en este proyecto?

ii. Cual podría ser alguna solución en este conflicto/problema?

5. Que factores han dirigido el proceso de decisión en relación al manejo del agua en este proyecto de represa? Usted considera que otros factores deberían ser incluidos? Cuales por ejemplo?

6. Como ha sido entregada la información para todas las personas involucradas en este proyecto? Ha sido esto accesible para cada persona?

7. Como su organización/institución ha buscado apoyo y redes con otras organizaciones/instituciones (a nivel nacional y/o internacional)

8. Que argumentos o posiciones de los diferentes grupos están presente en este proyecto?

9. Cuáles son las redes sociales que Usted ha identificado para cada uno de las partes interesadas en este caso? Hasta qué punto su organización/institución y otros deberían ser tomados en cuenta en el proceso de decisión?

10. Como le gustaría ver el rio Nuble en el futuro? Como debería ser el rio manejado? Y por quién?

11. Como Usted entiende el rol del rio en esta área? 
